JUN 231999 STH 4

ENGINEERING DATA TRANSMITTAL

2. To: (Receiving Organization)

Distribution

5. Proj./Prog./Dept./Div.:

S-Farm Overground Transfer (OGT) Line/Interim Stabilization Project

8. Originator Remarks:

For the S-Farm Overground Transfer (OGT) line between valve pits 241-S-B and 241-S/D, the attached Walkdown and Evaluation Report provides a summary of the existing design and condition of the pipeline and the improvements made during the final design and installation.

6. Design Authority/ Design Agent/Cog. Engr.: WF Zuroff/FDNW/JN Doeler
4. Related EDT No.:

$612795,612796,617982$, $617983,622129,622130$, 623332

7. Purchase Order No.:

N/A

9. Equip./Component No.:

N/A

10. System/Bldg./Facility:

TWRS/241-S (OGT)
11. Receiver Remarks: 11A. Design Baseline Document? [x] Yes [] No

Approval of the S-Farm Overground Transfer System Walkdown and Evaluation Report is indicated by signature on this EDT.

11.A. Refer to Design Verification for S-Farm Overground Transfer Line, HNF3381, Rev. 0, dated September 1998.
12. Major Assm. Dwg. No.:

N/A

13. Permit/Permit Application No.:

N/A

14. Required Response Date: March 17, 1998

\begin{tabular}{|c|c|c|c|c|c|c|c|c|c|c|}
\hline \multirow{2}{*}{$\begin{array}{c}15 . \\
\text { (A) } \\
\text { Item } \\
\text { No. }\end{array}$} & \multicolumn{6}{|c|}{ DATA TRANSMITTED } & \multirow{2}{*}{$\begin{array}{c}(F) \\
\begin{array}{c}\text { Approval } \\
\text { Desig- } \\
\text { nator }\end{array} \\
\end{array}$} & \multirow{2}{*}{$\begin{array}{c}\text { (G) } \\
\text { Reason } \\
\text { for } \\
\text { Trans- } \\
\text { mittal } \\
\end{array}$} & \multirow{2}{*}{$\begin{array}{c}(\mathrm{H}) \\
\text { Origi- } \\
\text { nator } \\
\text { Dispo- } \\
\text { sition }\end{array}$} & \multirow{2}{*}{$\begin{array}{c}\text { (I) } \\
\text { Receiv- } \\
\text { er } \\
\text { Dispo- } \\
\text { sition }\end{array}$} \\
\hline & \multicolumn{2}{|c|}{ (B) DocumentDrawing No. } & $\begin{array}{l}\text { (C) } \\
\text { Sheet } \\
\text { No. }\end{array}$ & $\begin{array}{l}\text { (D) } \\
\text { Rev. } \\
\text { No. }\end{array}$ & \multicolumn{2}{|c|}{ (E) Title or Description of Data Transmitted } & & & & \\
\hline 1 & \multicolumn{2}{|l|}{ HNF-3477 } & - & 0 & \multicolumn{2}{|c|}{$\begin{array}{l}\text { S-Farm Overground } \\
\text { Transfer Line Walkdown and } \\
\text { Evaluation Report }\end{array}$} & SQ & 1 & 1 & 2 \\
\hline \multicolumn{11}{|c|}{ KEY } \\
\hline \multicolumn{2}{|c|}{ Approval Designator (F) } & \multicolumn{4}{|c|}{ Reason for Transmittal (G) } & \multicolumn{5}{|c|}{ Disposition $(\mathrm{H}) \&(\mathrm{l})$} \\
\hline \multicolumn{2}{|c|}{ (Ret: HNF-PRO-233) } & $\begin{array}{l}\text { 1. App } \\
\text { 2. Rel } \\
\text { 3. Info }\end{array}$ & \multicolumn{3}{|c|}{$\begin{array}{l}\text { 4. Review } \\
\text { 5. Post-Review } \\
\text { 6. Dist. (Recoipt Acknow. Required) }\end{array}$} & \multicolumn{2}{|c|}{$\begin{array}{l}\text { 1. Approved } \\
\text { 2. Approved w/comment } \\
\text { 3. Disapproved w/comment }\end{array}$} & \multicolumn{2}{|c|}{$\begin{array}{l}\text { 4. Reviewed no/comment } \\
\text { 5. Reviewed w/comment } \\
6 \text {. Receipt acknowledged }\end{array}$} & \\
\hline
\end{tabular}

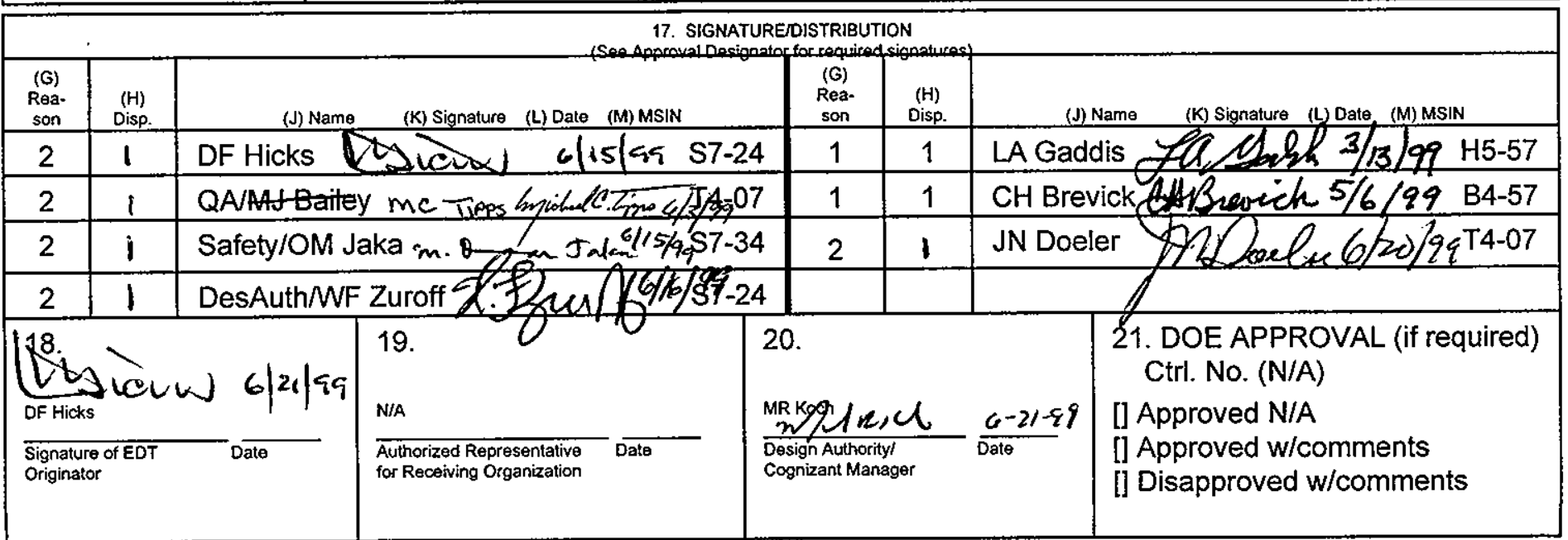


HNF-3477, Rev. 0

\section{WALKDOWN AND EVALUATION REPORT}

$S$

(ETN-98-0005)

\section{S-Farm Overground Transfer (OGT) System Valve Pit 241-S-B to Valve Pit 241-S-D}

Dale F. Hicks

Numatec Hanford Corporation, POB 1300, Richland, WA 99352

U.S. Department of Energy Contract DE-AC06-96RLi3200

$\begin{array}{llll}\text { EDT/ECN: } & 612794 & \text { UC: } & 721 \\ \text { Org Code: } & 83100 & \text { Charge Code: } 103360 / \text { EF00-528/50 } \\ \text { B\&R Code: } & \text { EW3120074 } & \text { Total Pages: } 96\end{array}$

Key Words: OGT, Overground Transfer, Interim Stabilization, 241-S, 241S-B, 241-S-D, saltwell pumping, walkdown, evaluation.

Abstract: This document addresses the initial investigation of the asfound condition of the partially constructed 241-S overground Transfer (OGT) system. It also addresses the evaluation of design deficiencies and their resolution, and includes before and after photographs, lists of drawings and Engineering Change Notices, and all design calculations.

TRADEMARK DISCLAIMER. Reference herein to any specific comercial product, process, or service by trade name, trademark, manufacturer, or otherwise, does not necessarily constitute or imply its endorsement, recommendation, or favoring by the United States Government or any agency thereof or $i$ ts contractors or subcontractors.

Printed in the United States of America. To obtain copies of this document, contact: Document Control Services, P.O. Box 950, Mailstop H6-08, Richland WA 99352, Phone (509) 372-2420;

Fax (509) 376-4989.
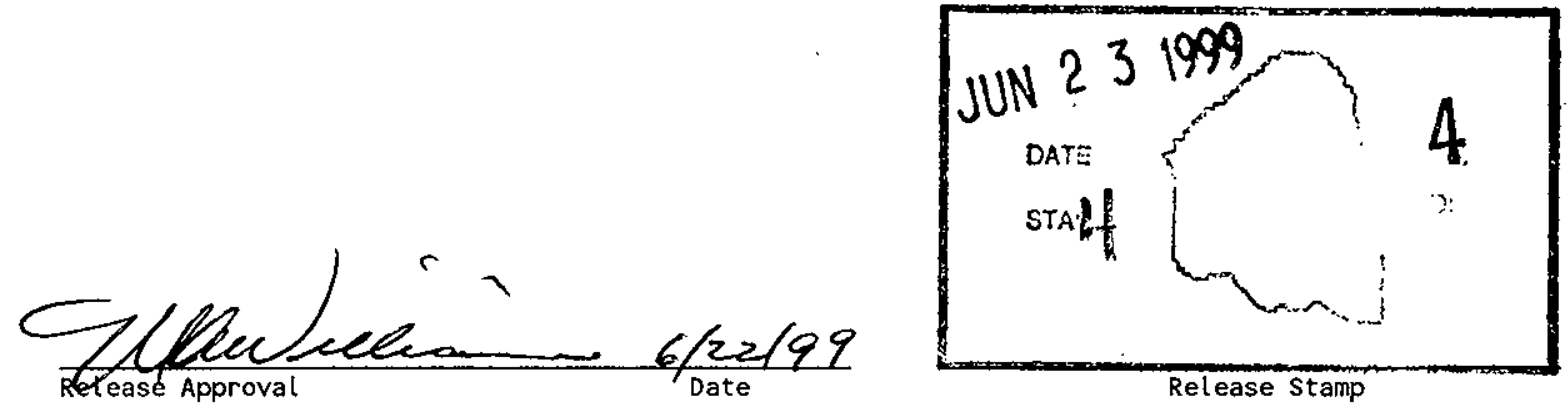

\section{Approved for Public Release}




\section{WALKDOWN AND EVALUATION REPORT}

\section{S-FARM OVERGROUND TRANSFER LINE \\ VALVE PIT 241-S-B TO VALVE PIT 241-S-D}

February 1999 


\title{
WALKDOWN AND EVALUATION REPORT
}

\author{
S-FARM OVERGROUND TRANSFER LINE
}

VALVE PIT 241-S-B TO VALVE PIT 241-S-D

February 1999

\section{FLUOR DANIEL NORTHWEST}

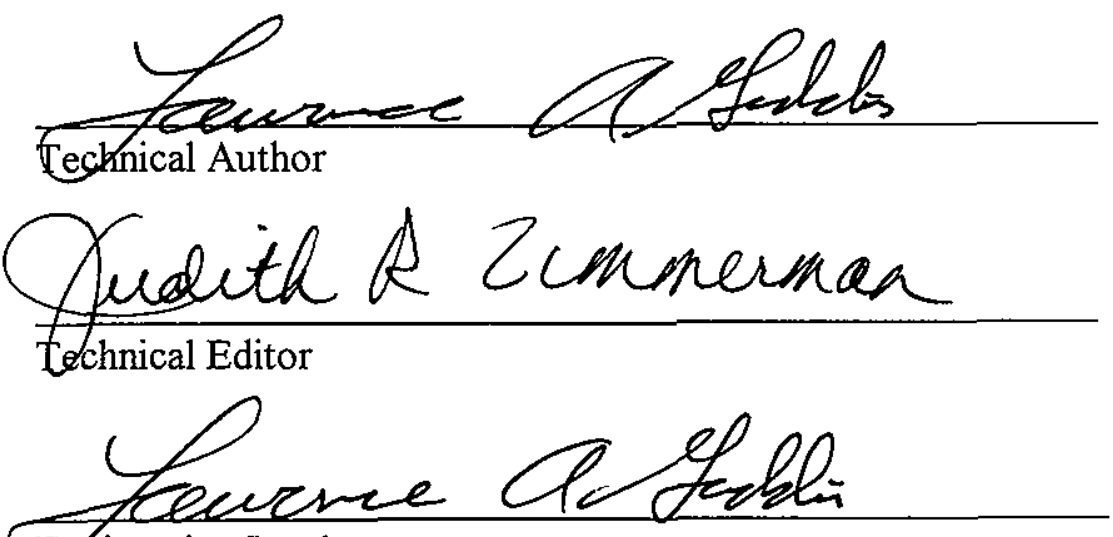

Engineering Lead
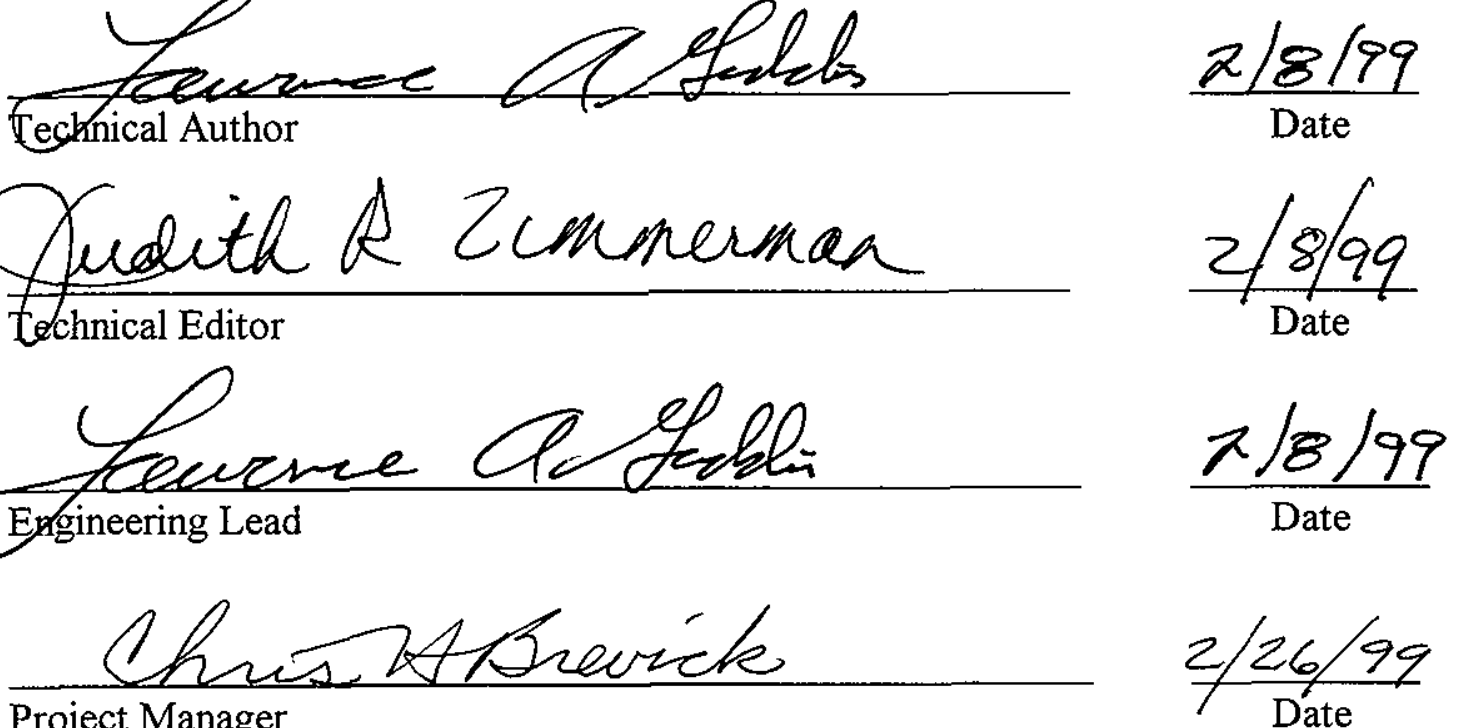

$\frac{2 / 26 / 99}{\text { Date }}$

\section{NUMATEC HANFORD CORPORATION}

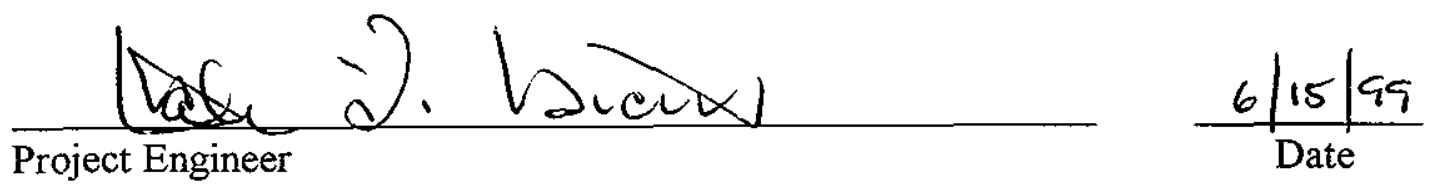




\section{TABLE OF CONTENTS}

INTRODUCTION

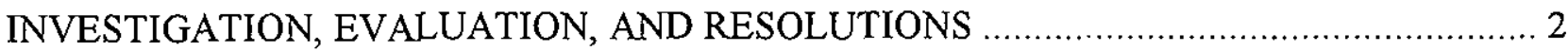

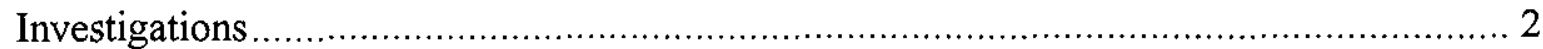

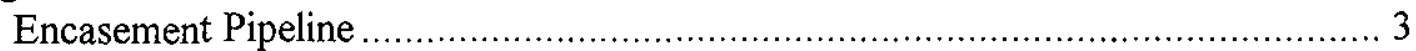

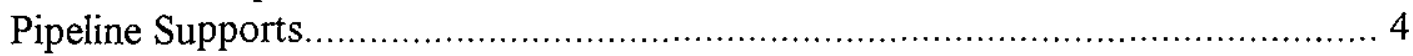

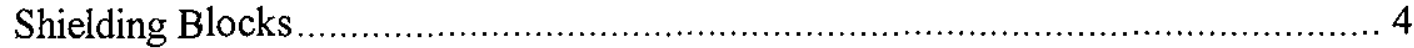

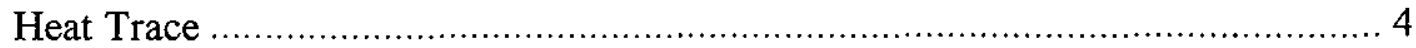

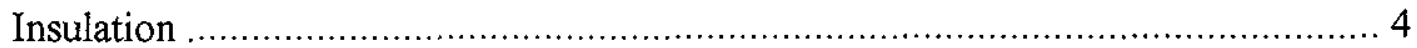

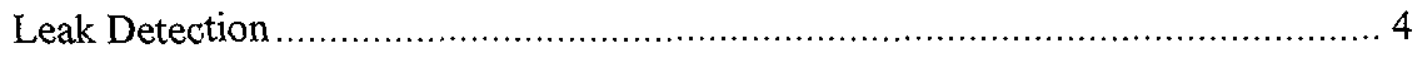

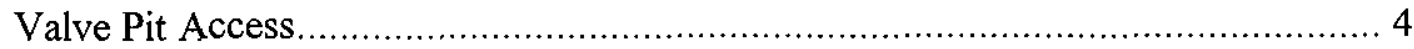

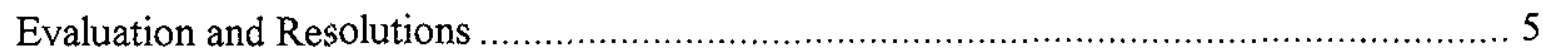

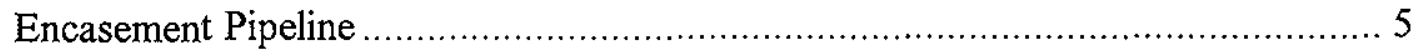

Pipeline Supports

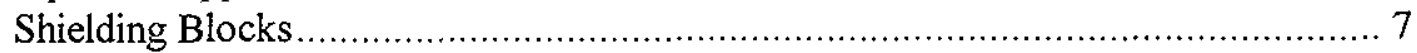

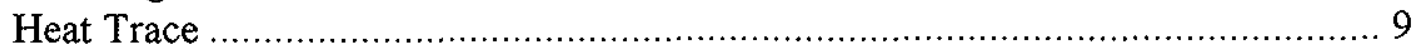

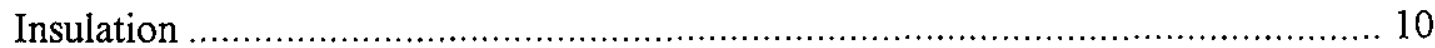

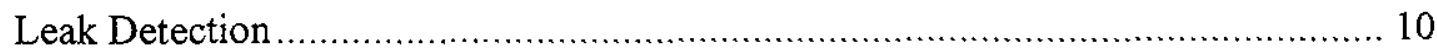

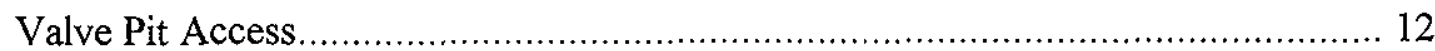

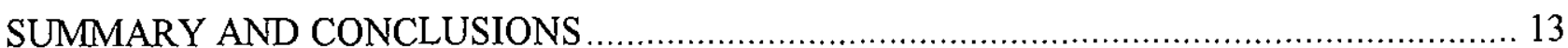

\section{APPENDICES}

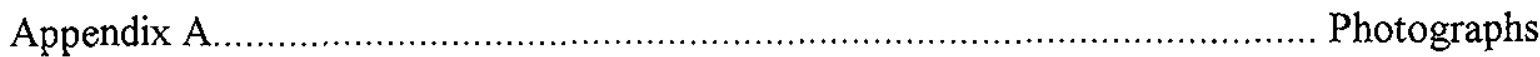

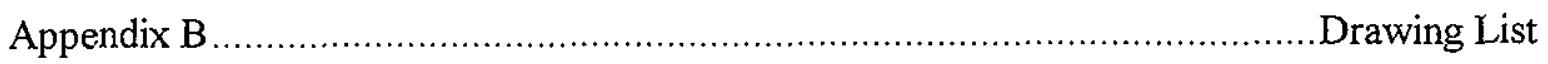

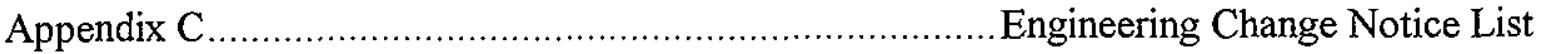

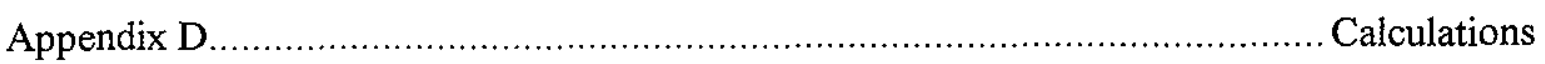




\section{WALKDOWN AND EVALUATION REPORT}

\section{S-FARM OVERGROUND TRANSFER LINE VALVE PIT 241-S-B TO VALVE PIT 241-S-D}

\section{INTRODUCTION}

Construction of the S-Farm overground transfer (OGT) line between transfer system pits 241-S-B and 241-S-D began in 1996. Fieldwork on the OGT line was suspended by a stop work at the close of FY 97, before the project was complete. In June 1998, Lockheed Martin Hanford Corporation (LMHC) issued a task order for the completion of the S-Farm OGT during the remainder of FY 98.

Fluor Daniel Northwest (FDNW) agreed to provide engineering and construction services, as necessary, to LMHC and Numatec Hanford Corporation (NHC) for completion of the construction of the S-Farm OGT line. FDNW will provide an acceptance of completed work (ACW) and support, as necessary, turnover of the OGT system to LMHC in compliance with the acceptance for beneficial use $(\mathrm{ABU})$ process.

The scope of work for this task was divided into three phases: investigation, engineering/design, and construction. The investigation phase was to determine the condition of the existing construction and the condition and extent of the unused material in the field and staging areas. This phase also provides input (cost estimate and schedule) toward establishing a path forward to completion.

This report presents the findings from the FDNW investigation of the existing S-Farm OGT construction as of June 1998 and of the construction documents, and describes the deficiencies identified. The report evaluation of the deficiencies, proposed alternative, and describes the resolution to the various design and construction problems identified. 


\section{INVESTIGATION, EVALUATION, AND RESOLUTIONS}

\section{Investigation}

The investigation phase for completion of the S-Farm OGT line started July 8, 1998, with a meeting to determine the remaining work scope. The meeting identified that the OGT effort should proceed with a review of the existing design and construction against the new design requirements of the Basis for Interim Operations (BIO) and evaluate the existing design of the OGT pipe supports and shielding blocks.

Following the meeting, the effort started with obtaining all available documents from the previous work efforts. A large collection of document were obtained from project management, including D. F. Hicks (NHC project engineer), D. D. Wiggins (LMHC responsible engineer), and C. H. Brevick (FDNW project manager). These documents included previous letters of instruction, statement of work, e-mail correspondence, meeting minutes, cost estimates, schedule, material information, and requisitions. Copies of the encasement pipe stress analysis, pipe support analysis, and the heat trace analysis were obtained from U. S. Department of Energy, Richland Operations Office (RL) records holding.

From the documentation package, the original project management, design engineering, and construction team members were identified. The documents identified the project control number, ER-5313, and included drawings developed for the OGT Line project. including H-2818279, sh. 1; H-2-818280, sh. 1; H-2-818281, sh. 1 and 2; and H-2-818283, sh. 1 . These drawings showed the typical piping installation for the OGT system and included details of various pipe spool assemblies, pipe support assemblies, heat tracing, and leak detection details. Drawings H-14-100414, sh. 1, 2, and 3 showed the concrete shielding blocks and included the construction specifications. A complete listing of all related drawings is included in Appendix B.

The construction job control system (JCS) package, WS-95-00163, was obtained from FDNW construction forces. From the JCS package, a listing of the drawings and engineering change 
notices (ECNs) used for the S-Farm OGT system construction prior to the stop work was obtained. The JCS package also provided insight that the S-Farm OGT system design was dictated primarily by ECNs. The JCS package identified 14 ECNs related to construction of the S-Farm OGT. From the site drawing control system, 36 ECNs have been issued against the OGT standard reference drawings. A complete listing of the related ECNs is in Appendix C.

Three nonconformance reports (NCR) were issued against the OGT system prior to the stop work. NCR ER5313-1 and ER5313-2 were general in nature, identifying problems with the encasement piping materials and shielding block fabrication. These two NCR's were closed before the stop work. NCR LMHC-98-010 was issued March 11, 1998, and identified problems with the OGT encasement pipe support spacing, configuration, and seismic qualifications. This NCR was still open at the start of this investigation.

Concurrent with the document search, a field walkdown of the completed S-Farm OGT construction was preformed on July 14, 1998. The walkdown verified current conditions and the remaining scope of the OGT system between valve pits 241-S-B and 241-S-D. Photographs taken of the existing installation are in Appendix A. The following deficient conditions were identified from the document review and during the walkdown:

1. Encasement Pipeline: The OGT encasement pipeline was not installed in accordance with original design package, ECN-626427. The pit entry spool pieces were located in accordance with the design package but the location and length of the various encasement pipe spool assemblies did not comply with the locations as shown on the ECN. Also, the encasement pipeline grade elevation and slope did not match the ECN.

2. Pipeline Supports: The pipe supports were not located as they were detailed on the drawings and the pipe supports were sitting on stacks of patio blocks (one to six blocks high). The supports were not anchored to the patio blocks, 15 of the 20 pipe supports were supported by more than one patio block and none of the blocks were attached to one another (see photographs in Appendix A). 
3. Shielding Blocks: In conjunction with the extensive elevation change identifying a revision to the pipe supports, it was determined that the concrete shielding blocks would interfere with the OGT pipeline. The configuration of the shielding blocks with a $915 \mathrm{~mm}(3-\mathrm{ft})$ leg would not allow any clearance between the pipe and the underside of the shielding blocks and, in some cases, the shielding blocks would be sitting directly on the pipeline.

4. Heat Trace: Two deficiencies were identified on the heat trace system. The first item was that the system had not been connected to a power source. The second deficiency was that the heat trace tape was not in contact with the $75 \mathrm{~mm}$ (3-in.) encasement pipeline.

5. Insulation: An inspection of the insulation materials for the encasement pipe and the fittings for the OGT system verified that sufficient material was available for completion of the project. The insulation material has been stored outside for approximately 2 years and some deterioration to the cellular glass was evident.

6. Leak Detection: The leak detection components for the S-Farm OGT system were to be installed within existing valve pits $241-S-B$ and $241-S-D$. These radioactive, contaminated pits were not visible or readily available during the walkdown.

7. Valve Pit Access: Following resolution of the above deficiencies, it was determined that the lead shielding plates were not on valve pit 241-S-D, as shown on ECN-626431.

During the walkdown, an inventory of residual materials and their location was taken to identify any shortages. This included a check of the concrete shielding blocks. These blocks were found stored at FDNW construction services support facilities in the 200-West Area. The blocks were in good condition with the special protective coating intact. The dimensions of these blocks were verified against original design drawing H-14-100414. 


\section{Evaluation and Resolutions}

After the document gathering and walkdown, the design and installation was evaluated based on current criteria, safety standards, and practices. Following are the evaluations and resolutions for the identified deficiencies identified during the walkdown and the review of the design documents.

1. Encasement Pipeline: The S-Farm OGT encasement pipeline design and construction criteria was primarily established by ECNs 626427 and 626429 . These ECNs referenced typical OGT drawings H-2-818279 and H-2-818280. Additional ECNs ER5313-7, $618349,619933,619934,620379,622123,622508,622513,622514,622518,622525$, 624949 , and 705781 had been issued detailing changes to reference drawings $\mathrm{H}-2-818279$ and $\mathrm{H}-2-818280$.

The intent of the encasement pipe is to contain leaks from the primary pipeline, allow any spilled waste to drain to the valve pits, and provide a means for detection of a leak. The primary pipe is a $25 \mathrm{~mm}$ (1-in.) flexible ethylene-propylene diene monomer (EPDM) with a stainless steel braided shielding. The grade elevation and slope of the pipeline is controlled primarily by the existing elevation on top of the valve pit walls. From field survey records, it was established that there was sufficient elevation change between the valve pits 241-S-B and 241-S-D to allow the encasement pipe to drain toward pit 241-SD. It was also determined impractical to change the encasement pipe spool assemblies because that would require changing of the primary pipe. Therefore, the pipeline location and configuration as previously constructed were not changed.

Drawing H-2-829564 sh. 1 was developed to show the as-built condition of the pipeline and the location of the various spool pieces. Following adjustment of the encasement line to the design grade elevation, the line's location was surveyed. This survey verified that the encasement pipe would drain.

To ensure proper installation of the encasement pipe, the pipe was pressure-tested as part of the initial construction in FY 97. This testing was documented in the JCS package. The encasement pipe supports had to be removed and replaced and the encasement pipe 
has been exposed to the weather for approximate 2 years. The support modifications and duration since the initial test caused concerns about the encasement pipe joint tightness. Retesting the encasement pipe would ensure integrity of the pipeline prior to installation of the pipe insulation and shielding blocks.

2. Pipeline Supports: The design and construction criteria for the pipe supports for the SFarm OGT encasement pipeline were originally established by ECN 626427. This ECN referenced OGT support (Assembly 3) on drawing H-2-818281.

The review of pipe support calculations showed a discrepancy between the assumed installation condition and the current design or field conditions. The original pipeline calculation assumed that the supports would be placed at $3.0 \mathrm{~m}(10-\mathrm{ft})$ intervals and that the OGT pipeline would be covered with a 3 -ft earthen berm. The earthen berm would provide stability, radiation shielding, and protection fof the OGT pipeline. Because the berm would have caused excessive tank dome loading, concrete-shielding blocks were selected to replace the berm. Additionally, the type of pipe support originally selected for the S-Farm OGT had support legs with a maximum length of $455 \mathrm{~mm}$ (18 in.), reference drawing H-2-818281, sh. 1, Assembly 3. This support allowed for only minor grade variation and would not compensate for the extensive ground elevation changes of SFarm. Patio blocks had been stacked under the pipe support in the low areas to bring the pipe to grade. Because it was anticipated that the pipeline would be covered by an earthen berm, there were no provisions for anchoring the support to the earth or the blocks. When the shielding blocks replaced the earthen berm, the pipe supports no longer provided support for the pipe in a natural phenomenon (seismic event). These changes were not reflected in the original analysis of the pipe or pipe supports.

The following resolutions were made to resolve the pipe support deficiencies. The supports were located at a maximum spacing of $3.0 \mathrm{~m}(10 \mathrm{ft})$ in accordance with the original design criteria. This spacing provides assurance that the encasement pipeline will remain at the desired grade and slope. The second revision was to replace the support 
base and vertical members of the pipe supports. Exchanging the patio blocks with a concrete base and adding longer vertical support legs provided a stable support capable of withstanding a natural phenomenon. The bases are now precast concrete (compressive strength 21-MPa (3000-psi)) with an embedded P3256 Unistrut channel member. The imbedded channel allows for anchoring the vertical pipe support legs to the concrete blocks. The longer support legs provided for the placement of the base directly on the existing ground and allowed direct support of the pipeline.

The calculations have been revised for the encasement pipe and supports to reflect the current design, including wind and seismic loading, ensuring that pipe stress levels and support loads are within acceptable limits and tank farm safety requirements. A copy of the calculation is included in Appendix D. Layout of the pipeline, the location of the pipe supports, and details on the pipe supports are shown on drawing H-2-829564, sh. 1 and 2.

The resolution for NCR LMHC-98-010 was established by development of the calculations and drawings listed above for the S-Farm OGT encasement pipe and supports.

3. Shielding Blocks: The design and construction criteria for the shielding of S-Farm OGT encasement pipeline was originally established by 2 ECNs, 626427 and 626429 . These ECNs referenced typical OGT drawings H-2-818284 and H-14-100414. The reference to drawing H-2-818284 in ECN 626427 was changed to H-14-100414 by ECN 626432. ECN 622125 was issued against the typical OGT installation drawing but did not directly affect the S-Farm OGT. ECN ER5313-8 affected the procurement of the shielding block and was not applicable to the installation of the blocks.

The precast concrete shielding blocks, procured offsite from The Utility Vault Company, were constructed in accordance with drawings $\mathrm{H}-14-100414$ sh. 1, 2, and 3. From the review of the shielding block design, the walkdown of the OGT pipeline, and the 
evaluation of the pipeline and the supports, it became apparent that the encasement pipeline was too high for the shielding block to properly fit over the pipe.

It was impractical to increase the size and height of the shielding blocks, and the pipeline elevation could not be lowered. Therefore, it was determined that additional material had to be placed below the pipeline to bring the ground to the desired finished grade to support the shielding blocks between valve pits 241-S-B and 241-S-D. Compacted gravel fill was placed along the pipeline, approximately $2.1 \mathrm{~m}(7 \mathrm{ft})$ wide and at varied depths of 0 to $150 \mathrm{~mm}$ (6 in.) (see drawing H-2-829565 sh. 1). The gravel raised the shielding blocks to allow for a minimum clearance of $50 \mathrm{~mm}$ ( 2 in.) between the underside of the shielding block and the pipe insulation around the pipe. Concurrent with the survey of the encasement pipeline, the grade elevation for the gravel was set to ensure that the shielding blocks would not interfere with the encasement pipeline or pipe supports.

The document research did not find calculations for the stability of the shielding blocks. Therefore, calculations based on the current design that included impact, wind, and seismic loading were prepared for the shielding blocks (see Appendix D).

With the additional gravel required to provide support for the shielding blocks, the allowable tank dome loading was affected. Calculations were required to determine acceptability of the revised dome loading. Information was supplied to LMHC for the evaluation of and revisions to the tank dome loading calculations. This evaluation proved that the OGT system and construction loads would not exceed allowable S-Farm singleshell tank loading.

During initial construction of the encasement pipeline, the spool pieces near valve pit 241-S-D were inadvertently changed from a single $1.5 \mathrm{~m}(5-\mathrm{ft})$ section to two $0.6 \mathrm{~m}(2-\mathrm{ft})$ sections. This $0.3 \mathrm{~m}(1-\mathrm{ft})$ reduction between the pit entry spool piece and the $45^{\circ}$ elbow directly affected the allowable length for the shielding blocks. As discussed previously, 
revising the encasement pipeline spool pieces was not practical. Therefore, a $0.3 \mathrm{~m}$ (1-ft) section was cut off the end of the shielding block at valve pit 241-S-D.

All the above discussed modifications and resolutions were incorporated into drawings for the S-Farm OGT (see drawings H-2-829565, sh 1 and 2).

4. Heat Trace: The original design and construction criteria for the heat trace for the S-Farm OGT system was established by ECN 626427. This ECN referenced typical OGT system installation drawings H-2-818279. ECNs ER5313-5, 627903, and 629463 were issued to detail changes to the heat trace system and to the drawings.

The installation of the heat trace system and connection to a power supply was in process when the stop work was issued. At that time, the design and construction met established criteria. Between the stop work and authorization to complete, operational criteria changed. To ensure continued integrity of the heating system, heat-tracing requirements were changed to require redundant heat trace cables. The new heat trace cable system had to be capabie of maintaining the encasement pipe at a temperature of $45^{\circ} \mathrm{C}\left(113^{\circ} \mathrm{F}\right)$. The heat trace system required ground fault protection to meet National Electrical Code (NEC) requirements. Additionally, the original specified circuit connection for the OGT heat trace system had been reassigned for another use and new $\mathrm{H}-14$ drawings were developed to identify the S-Farm electrical circuits.

Original drawing $\mathrm{H}-2-818279$ showed that the heat trace cable would be spirally wrapped around the $75-\mathrm{mm}(3-\mathrm{in}$.) encasement pipeline and secured with Velcro TM straps at 900 mm (3-ft) spacing. ECN 627903 changed this wrapping to a straight run along the bottom of the pipe with the Velcro TM straps still at $900 \mathrm{~mm}$ (3-ft). This strapping method did not ensure continuous contact of the heat trace cable to the encasement pipeline.

To resolve the identified deficiencies and criteria changes, the following resolutions were incorporated into the heat trace system. The existing heat trace cable was removed and 
spared at the request of NHC. Two heat trace cables and two heat trace circuits were provided to ensure a continued heat source for the encasement pipeline. The new heat trace cable system will be capable of maintaining the encasement pipe at a temperature of $45^{\circ} \mathrm{C}\left(113^{\circ} \mathrm{F}\right)$. Ground fault protection equipment (GFPE) circuit breakers were installed in newly provided panelboards located near each pit. In addition, local temperature indicators were installed on each end of the pipeline for monitoring the pipeline temperature. To ensure that the heat trace cable remained in contact with the encasement pipeline, the Velcro TM straps were replaced with light gauge stainless-steel sheet metal shroud. The shroud was strapped to the pipeline with stainless-steel straps. The new heat trace installation is shown on drawings H-2-829564, sh. 1 and H-2-829566, sh. 1 and 2.

5. Insulation: The original design and construction criteria for S-Farm OGT encasement pipe insulation were established by ECN 626427. This ECN referenced to typical OGT installation drawings H-2-818279.

The deterioration of the cellular glass could prevent a tight butting of the individual insulation pieces. To ensure that all the pieces fit tightly together, those pieces with any degradation were trimmed to ensure a proper fit in accordance with manufacturer requirements. The insulation installation detail is shown on drawings H-2-829564, sh. 1.

6. Leak Detection: The original design and construction criteria for the leak detection of the S-Farm OGT system were established by ECN 626427. This ECN referenced typical OGT installation drawing H-2-818283. ECNs ER5313-2, ER5313-3, ER5313-4, ER5313$6,627903,629470,629503,629583$, and 633169 were issued to detail changes to the leak detection system and to the drawings.

The installation of the OGT leak detection system and connection to the S-Farm system was in process when the stop work was issued. At that time, the design and construction met established criteria. Between the stop work and authorization to complete, the 
operational criteria changed. It was determined that the existing leak detection systems would be modified to adequately detect a leak. The existing leak detector was installed to detect a leak with the encasement drain valves closed. This would have pressurized the encasement line and was not acceptable to current criteria.

To resolve the identified deficiencies and criteria changes, the following resolutions were incorporated into the S-Farm OGT leak detection system. A drip leg was added down stream of each drain valve to allow liquid to accumulate for leak detection. The leak detection wiring was routed from the detector in the valve pit to a termination box located on the outside of valve pits 241-S-B and 241-S-D. Tank farm operations will connect the wiring in the termination boxes into the S-Farm leak detection relay system in the future. The new leak detection installation is shown on drawings H-2-829564, sh. 2 and H-2829566, sh. 1 and 2.

7. Valve Pit Access: Pit access design and construction criteria for the S-Farm OGT system was established by ECN 626429 . This ECN referenced to customer-supplied $25 \mathrm{~mm}$ by $1.2 \mathrm{~m}$ by $2.4 \mathrm{~m}$ (1-in. by 4 -ft by 8 -ft) carbon steel cover plate. ECNs 623918 and 623923 modified the steel cover plates and ECNs 623920, 626430, and 626431 added a leadshielding plate on top of the steel cover plates.

For pit entry of the S-Farm OGT, one of the two cover blocks has to be removed from both valve pits $241-\mathrm{S}-\mathrm{B}$ and $241-\mathrm{S}-\mathrm{D}$. With the pit entry of the OGT system, it is no longer practical to replace the original cover block while the system is operating. The steel plates provide the required cover for the pit and the lead plates provide radiation shielding while the OGT is in service. The missing lead shielding plate from valve pit 241S-D needs to be installed prior to operation of the S-Farm OGT system. Drawing H-2829565 , sh. 2 includes the design of the steel and lead-shielding plate as previously shown on the ECNs. 
As determined by a review of the design documents, numerous ECNs dictate the design of the SFarm OGT line. Thirty-six ECNs were written against the standard OGT system drawings. This large number of ECNs makes evaluation of the design and construction very cumbersome and complicated. Construction services had identified only 14 of the ECNs in the construction JCS package.

ECN 626427 was the initial document that identified the installation of the S-Farm OGT system. This ECN showed two OGT systems, one between valve pits 241-S-B and 241-S-D and a second between the pump pits on tanks 241-S-103 and 241-S-106. The second system between the two tanks is no longer required and will be omitted during document consolidation.

NHC and LMHC have requested a review of the existing outstanding ECNs for the OGT systems and consolidation, deletion, or incorporation of the ECNs into manageable design documents. Combining the ECNs will allow for better documentation of the OGT system installation. This consolidation will also simplify the eventual removal of the S-Farm OGT line and removal of the design document from the tank farm files.

Review of the construction documents identified the need to revise all project documents to the new design. This included revision to the installation instruction, critical lift procedure, job control package, radiation work permit, as-low-as-reasonable-achievable (ALARA) management worksheet, excavation permit, and vehicle routing map.

\section{SUMMARY AND CONCLUSIONS}

The investigation of the S-Farm OGT system began in July 1998. The investigation determined that construction of the S-Farm OGT system was approximately $40 \%$ complete. The status of the major elements of the system at that time included:

- The primary and encasement pipelines, including the pit entry spool pieces, were installed between valve pits $241-\mathrm{S}-\mathrm{B}$ and $241-\mathrm{S}-\mathrm{D}$. 
- The heat trace for the encasement pipeline was installed but not connected to a power source.

- The leak detection sensors were in place but not connected to a monitoring system.

- The pipe insulation was being stored at the FDNW laydown yard.

- The shielding blocks had been procured but not installed.

The document research and installation walkdown identified several deficiencies with the S-Farm OGT system, including:

- Encasement pipeline configuration was not according to the drawings.

- Pipe supports were unstable.

- Interference between the encasement pipeline and the shielding blocks.

- The heat trace cable was not in contact with the encasement pipeline.

- The lead shielding plates were not on valve pit 241-S-D.

Numerous ECNs dictated design and construction. Thirty-six ECNs were written against standard OGT system design drawings and only 14 of those were documented in the construction JCS package. The large number of ECNs issued has complicated the design and construction of the S-Farm OGT.

To resolve the identified deficiencies and complete the construction of the S-Farm OGT, the following actions were taken:

- Generated four civil/piping design drawings from numerous ECNs.

- Generated two electrical/instrumentation design drawings for the heat trace and leak detection system.

- Issued an ECN for designation of the heat trace power circuit.

- Issued ECNs to supercede or void $13 \mathrm{ECNs}$ used for the original OGT design.

- Produced an installation instruction document for construction of the OGT, reference HNF-3479. 
- Evaluated the four possible accident scenarios as identified in the BIO against the revised design reference HNF-3478.

- Worked closely with construction to resolve deficiencies and provided cost-effective solutions.

- Prepared the Construction Integrity Assessment Report, HNF-4445, in accordance with WAC-173-303-640 (3)(c).

The drawings and ECNs show the as-built configuration of the encasement pipeline, define the location and new design of the pipe supports, define the locations of the shielding block and joint covers, and provide for additional gravel material to be placed under the shielding blocks so that the blocks do not rest on the pipeline. The drawings show the revised leak detection system and heat tracing system, and include the power connections for the heat trace. The OGT standard drawing will also be updated to include other outstanding ECNs as applicable.

The analysis of the encasement pipe, pipe supports, heat tracing, and tank dome loading have been prepared or updated to reflect the current design and to meet the criteria established by the tank farm BIO.

Construction forces updated the critical lift procedure, the JCS package, and work permits to match the revised design. The construction of the S-Farm OGT was completed in accordance with the revised and released drawings and the latest tank farm BIO requirements. 


\section{APPENDIX A}

\section{PHOTOGRAPHS}

Initial Walkdown

Progress Photos $, \ldots \ldots \ldots, \ldots$, A 8

Final Walkdown $, \ldots \ldots, \ldots, \ldots, A-17$ 
HNF-3477, Rev. 0
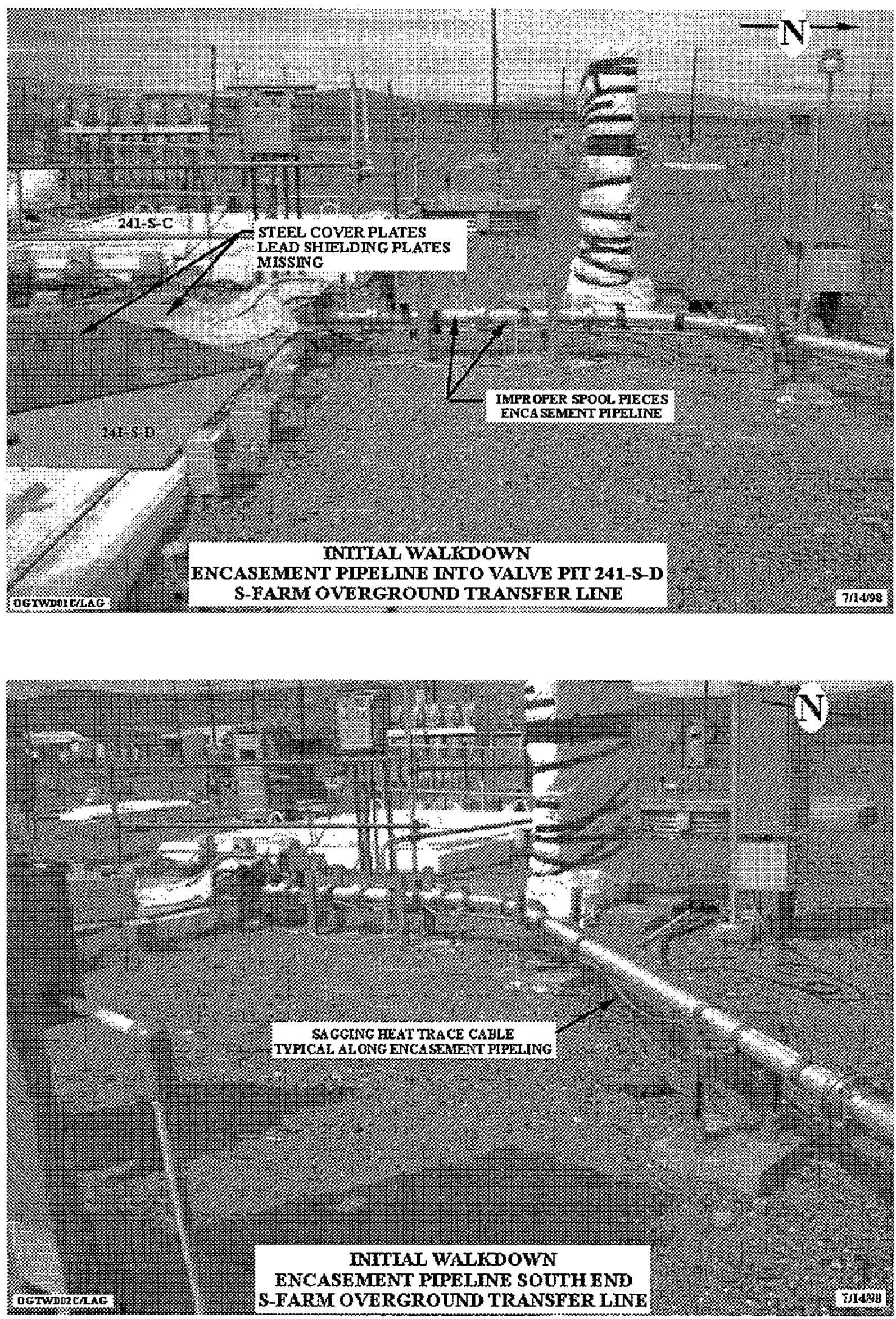
HNF-3477, Rev. 0
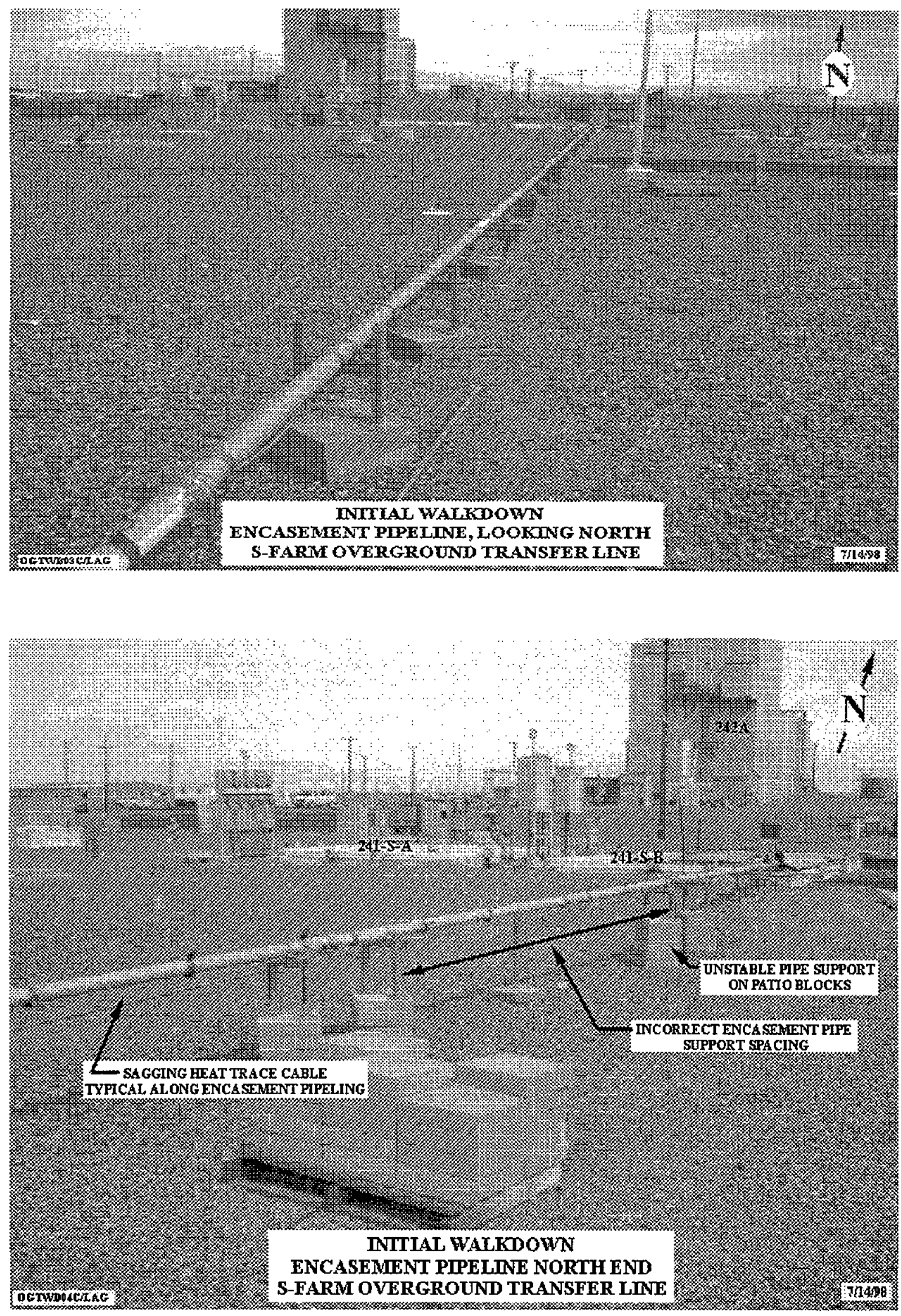
HNF-3477, Rev. 0
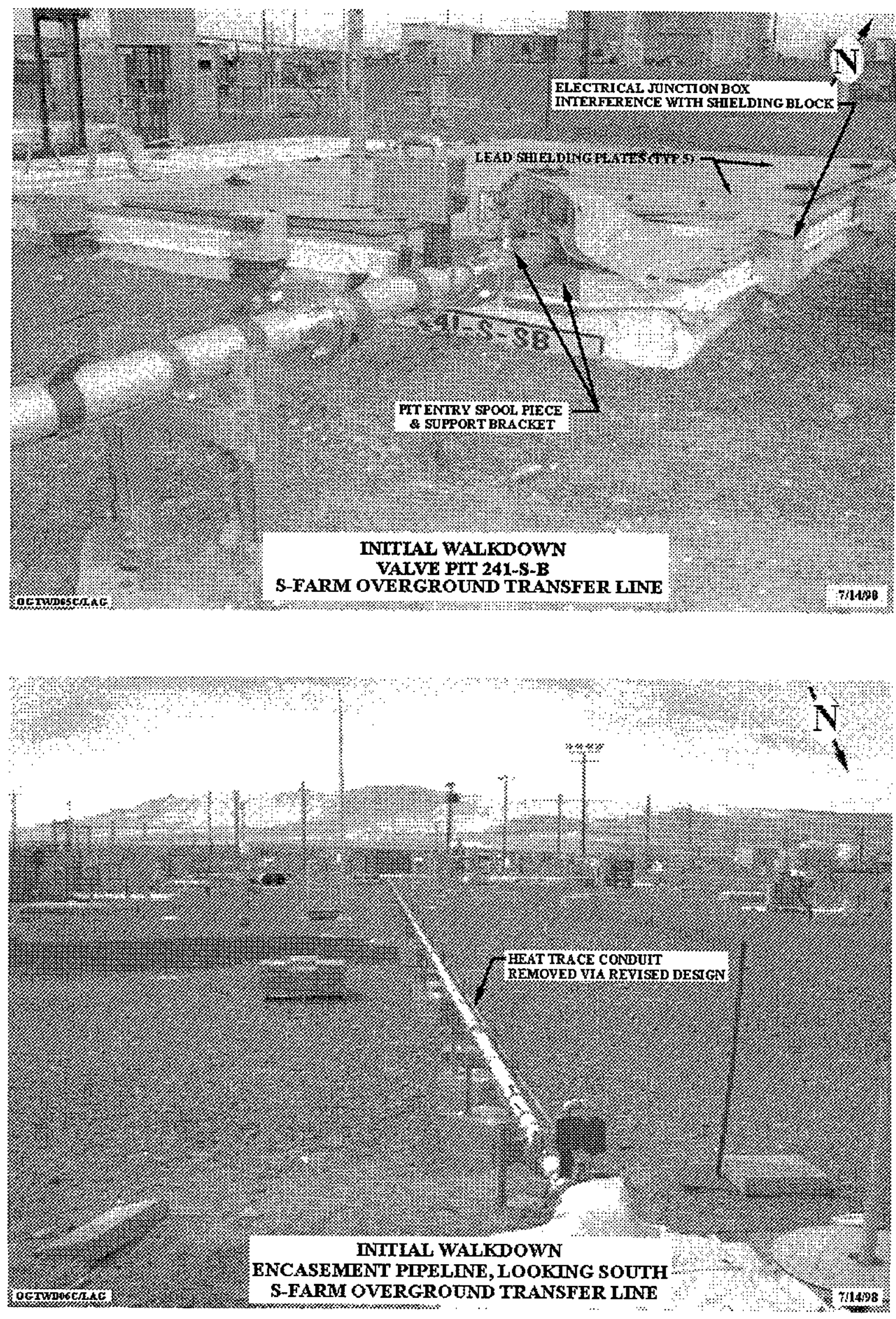
HNF-3477, Rev. 0
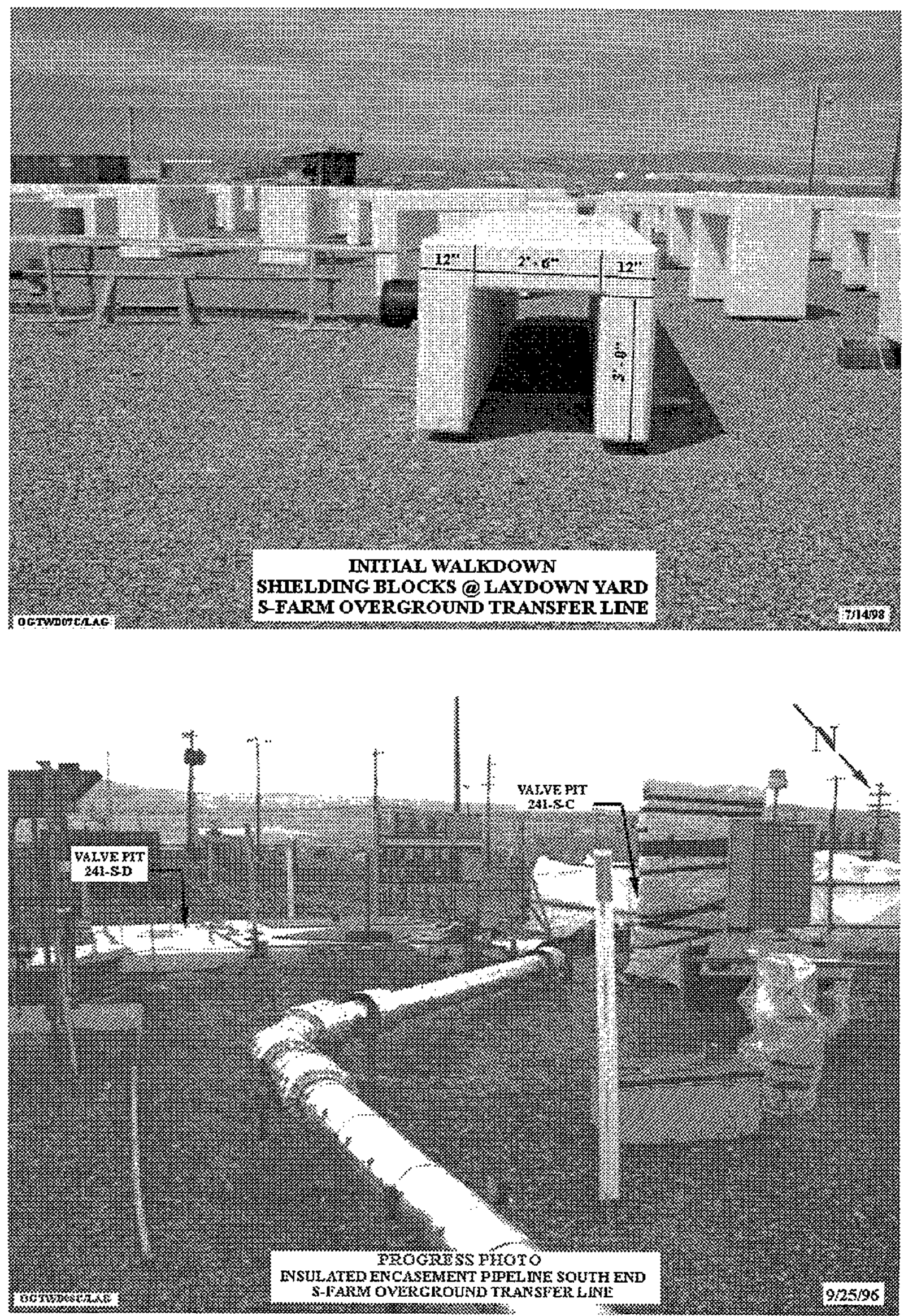
HNF-3477, Rev. 0
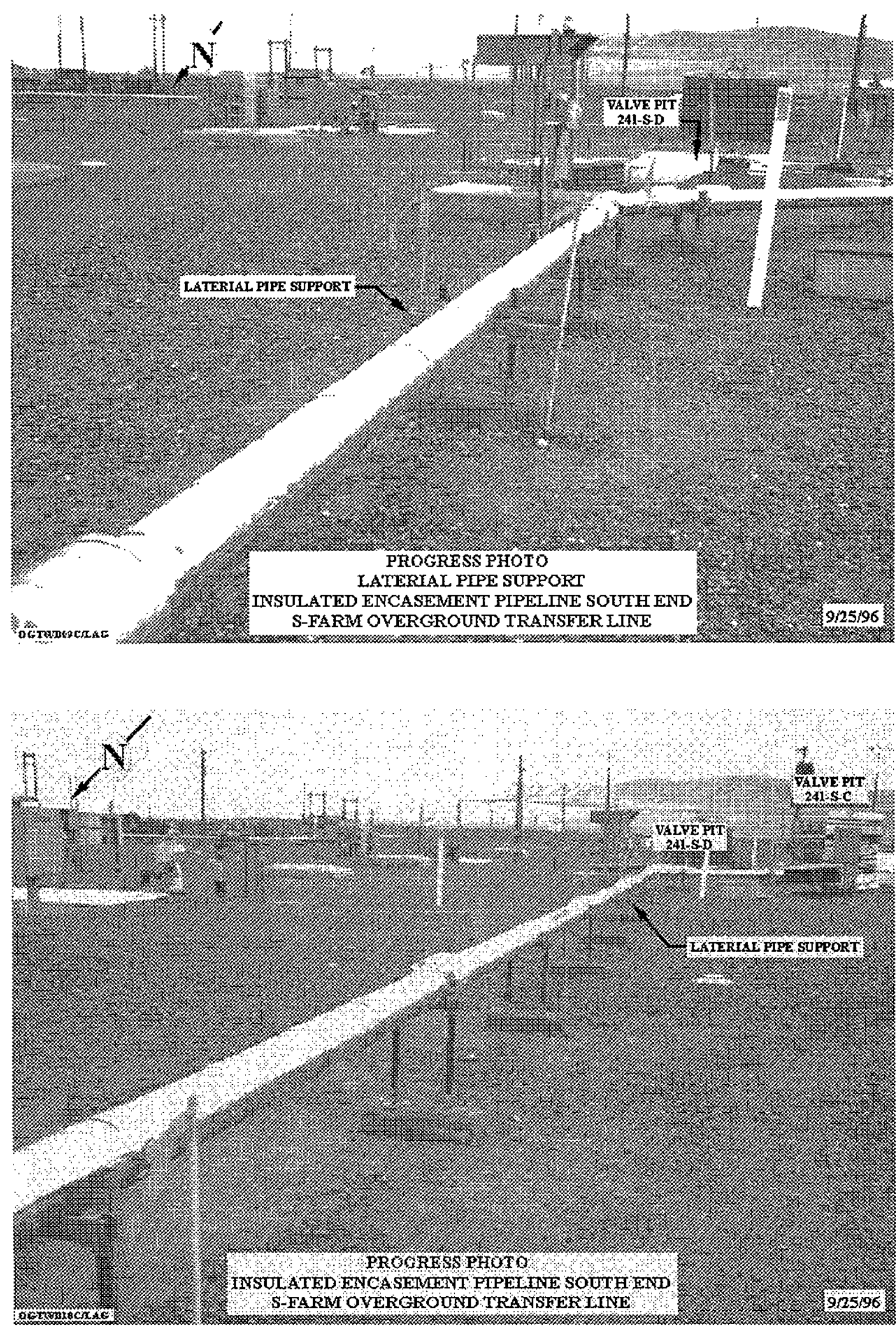

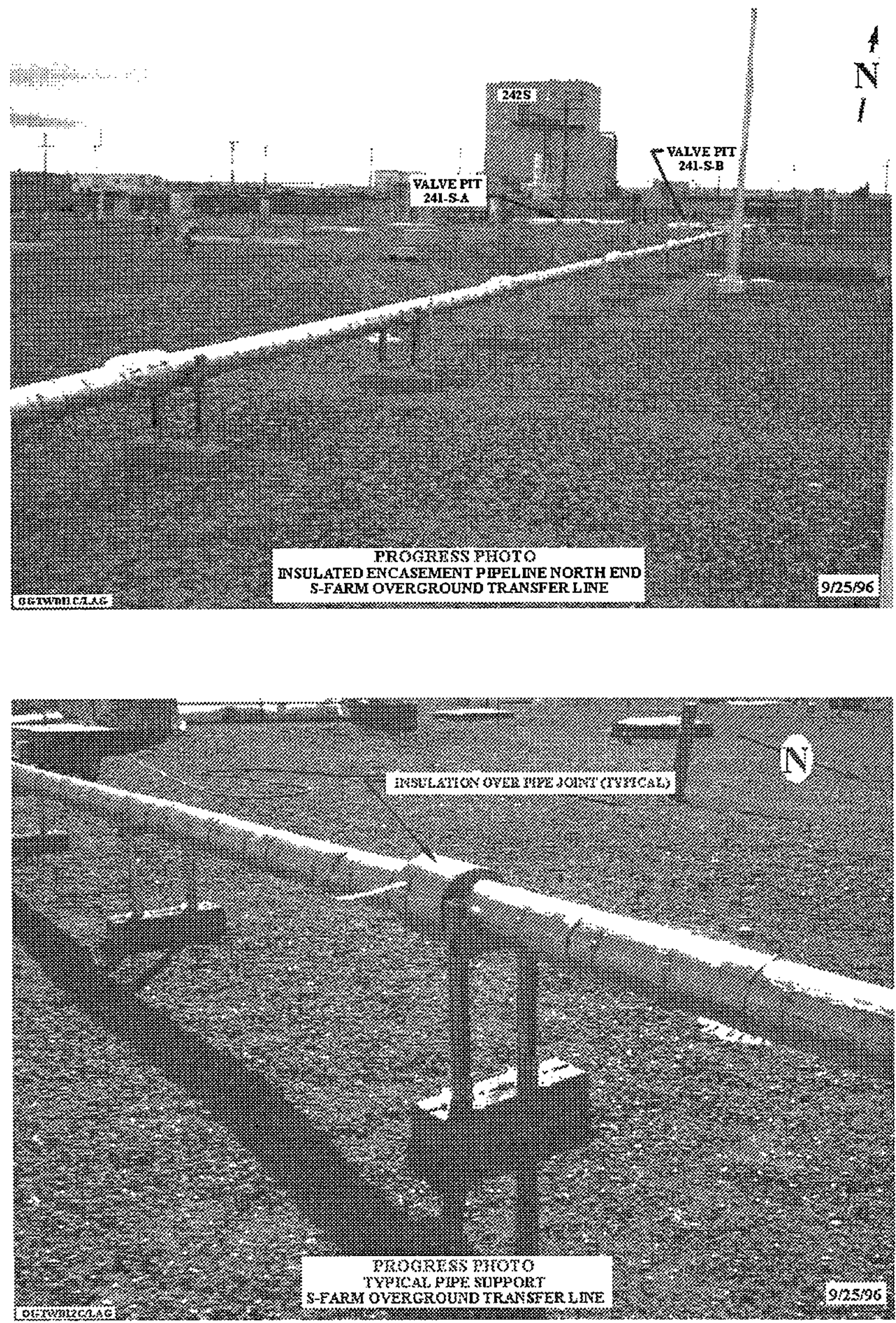
HNF-3477, Rev. 0
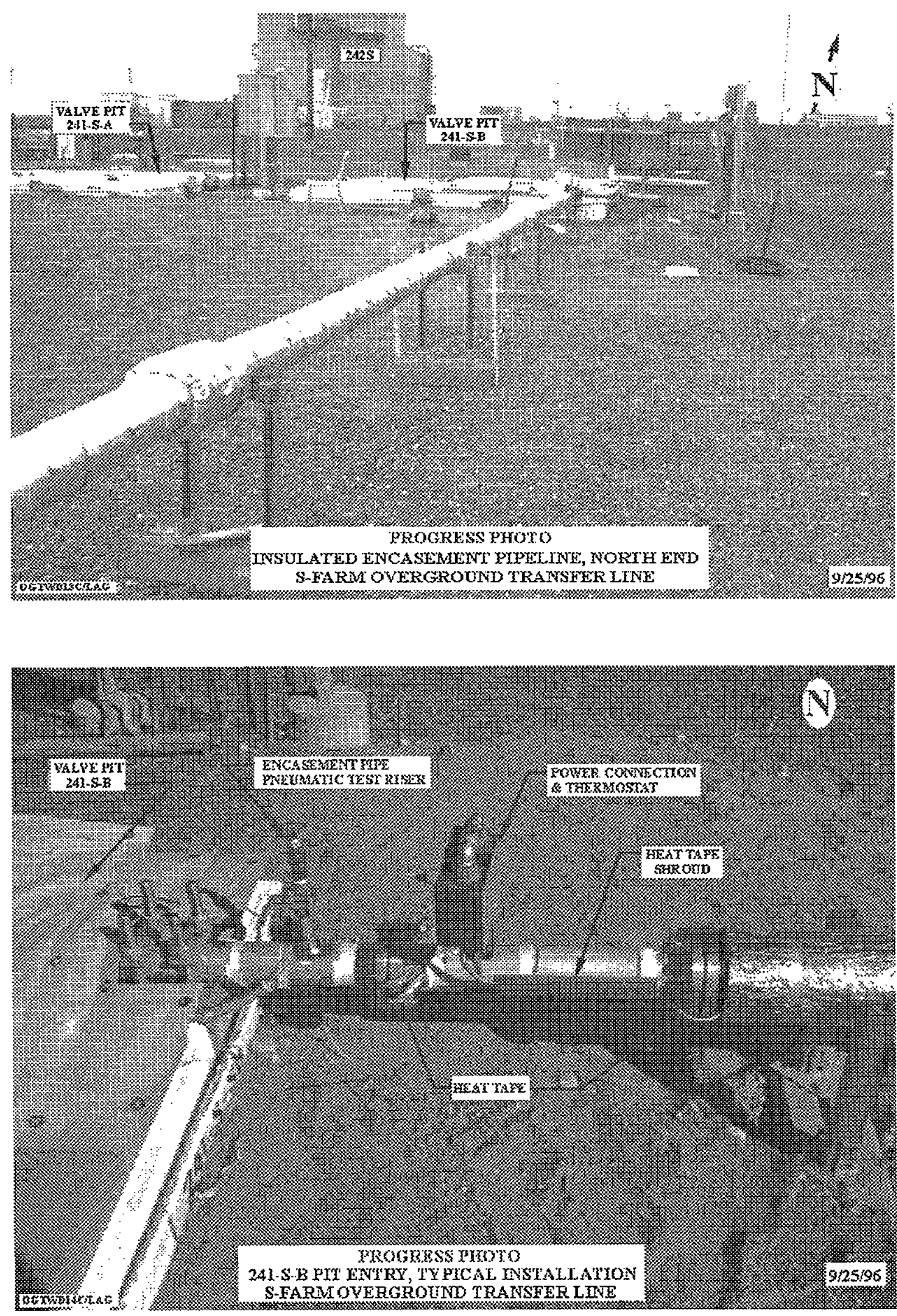
HNF-3477, Rev. 0
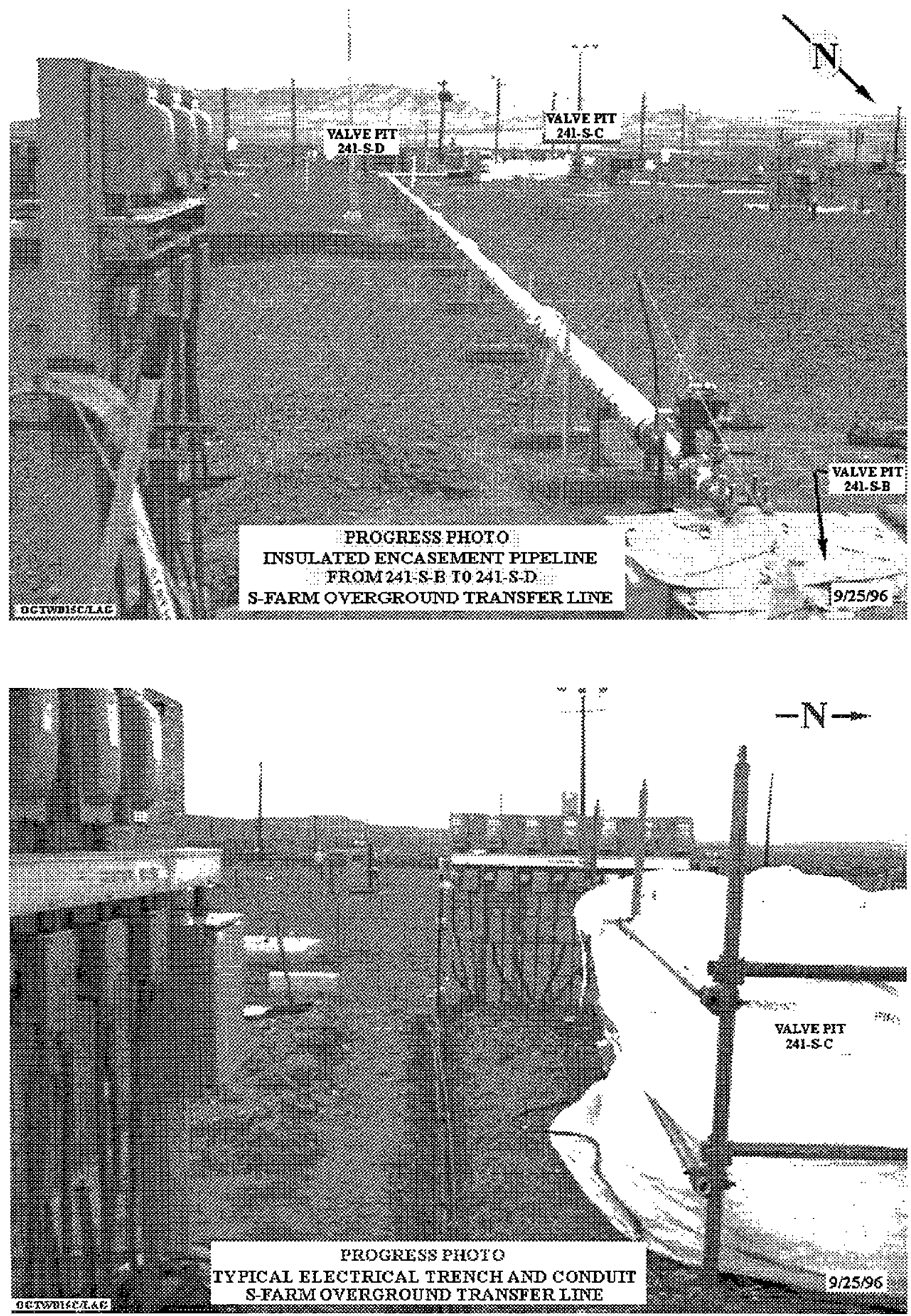

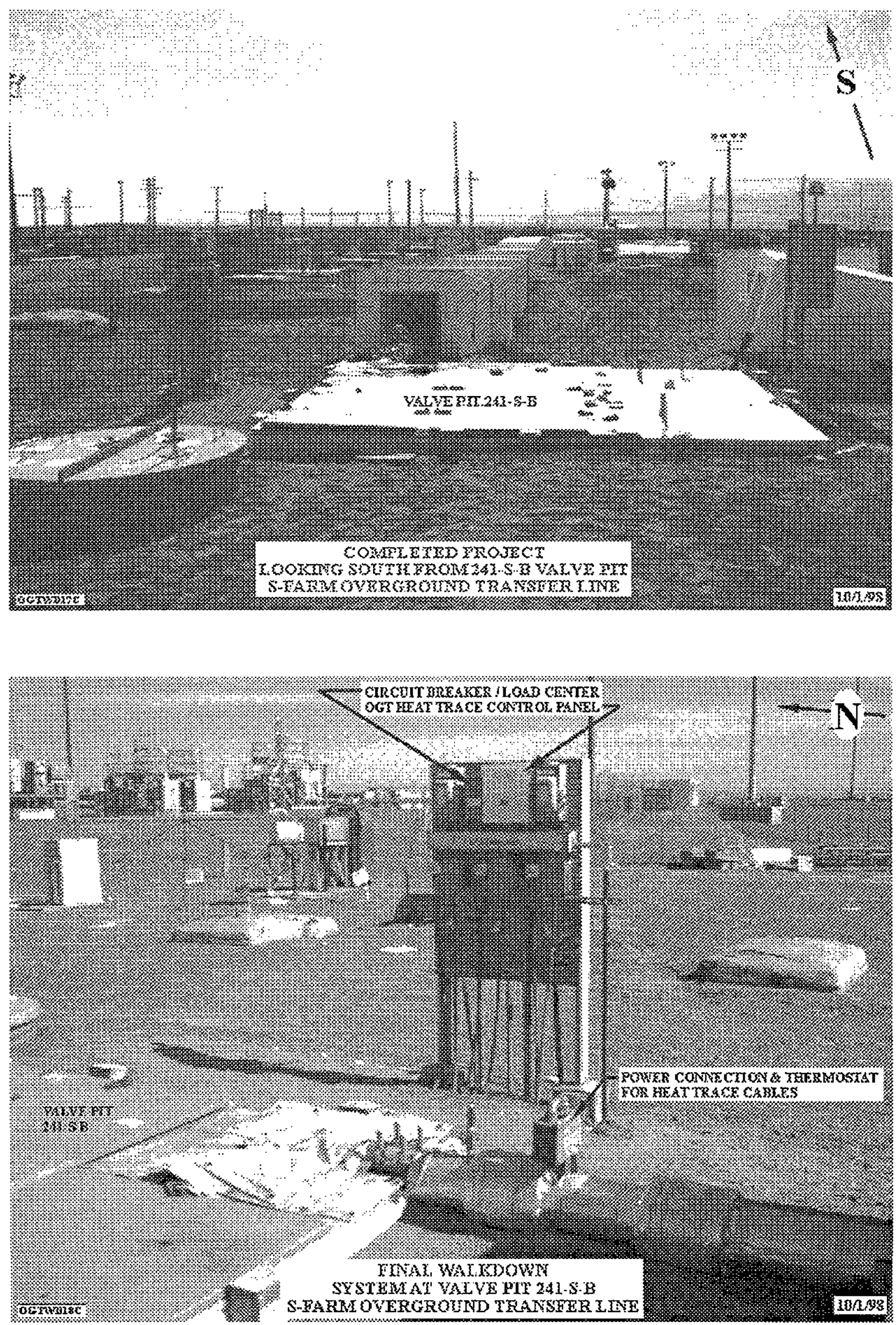
HNF-3477, Rev. 0
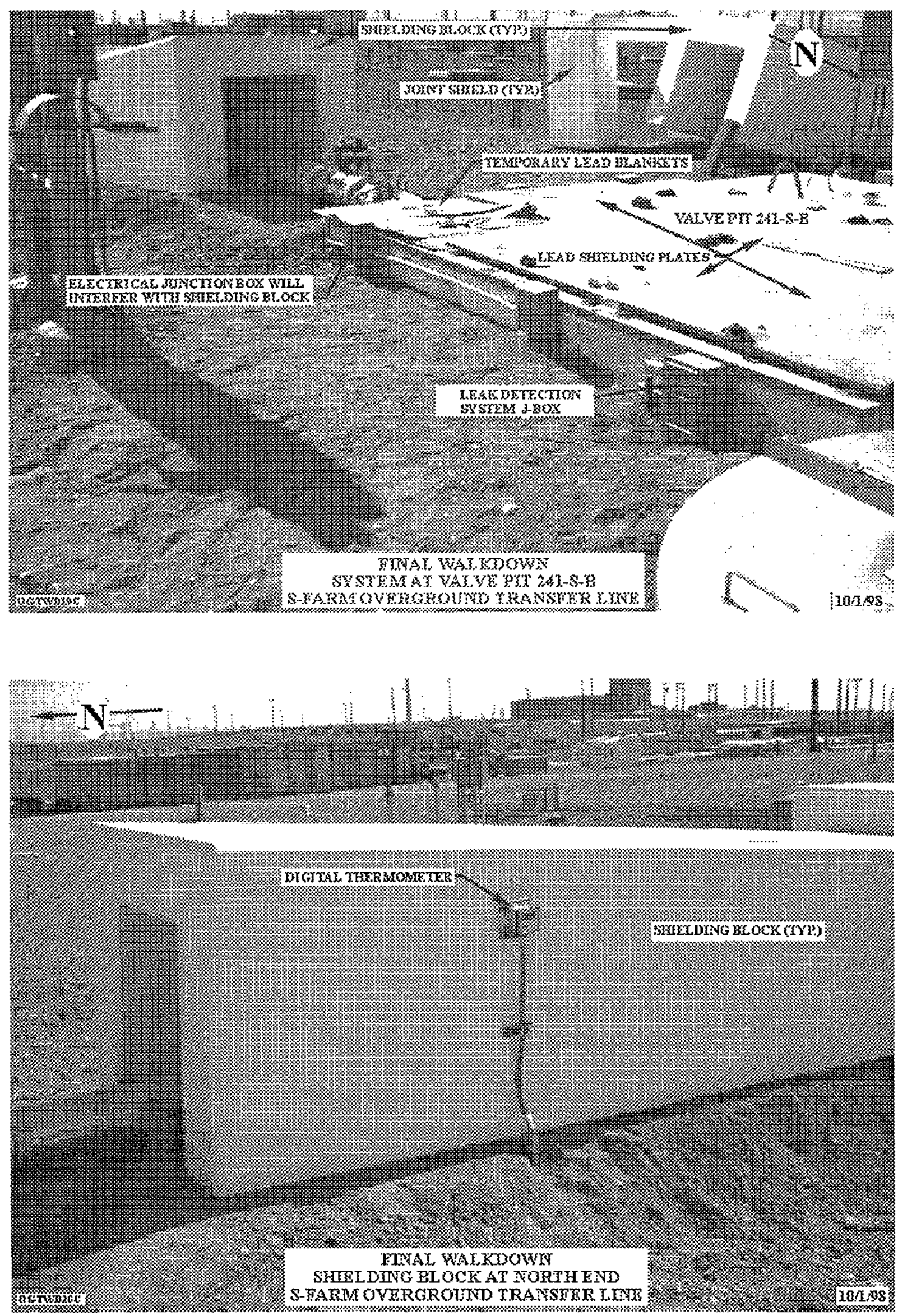

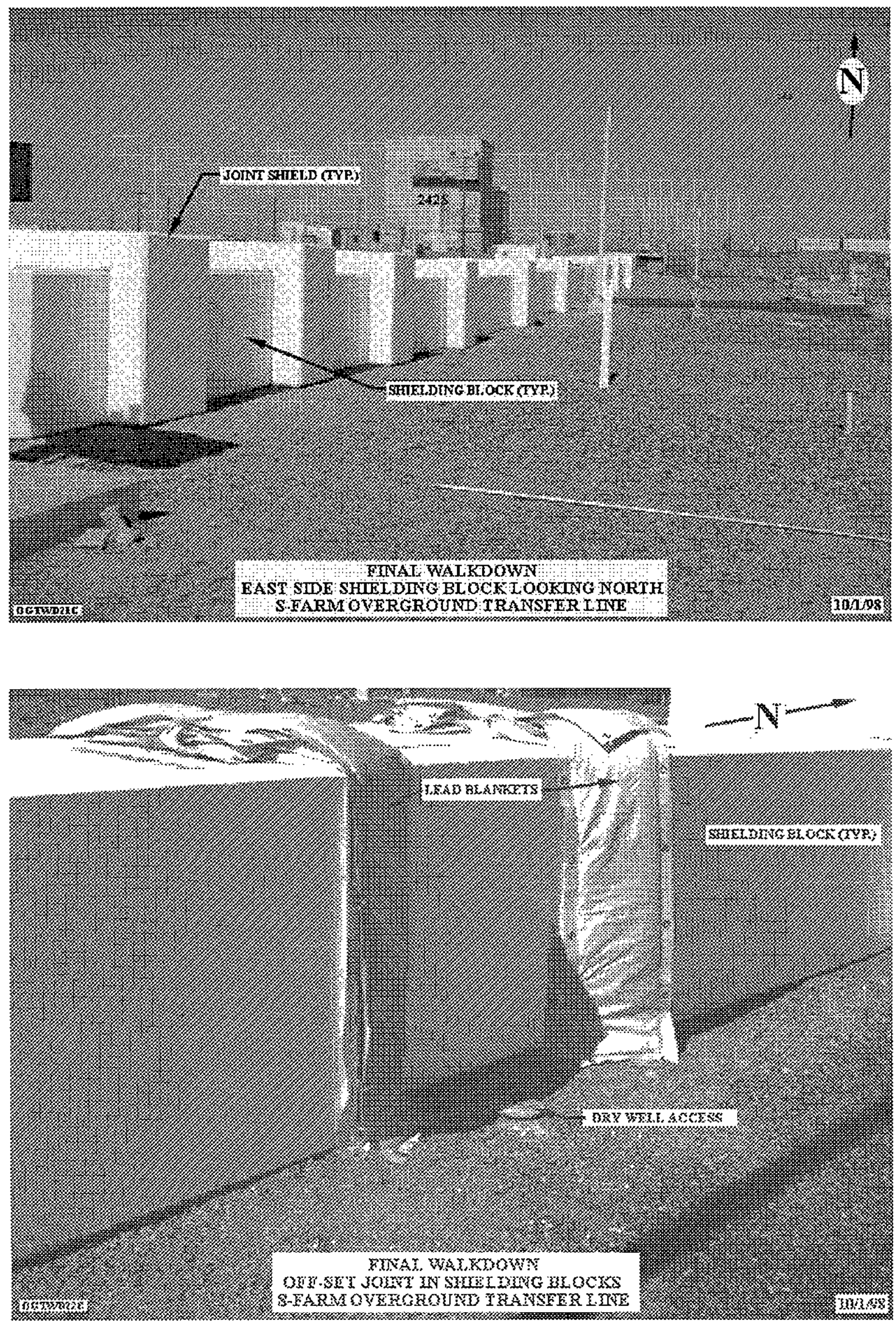

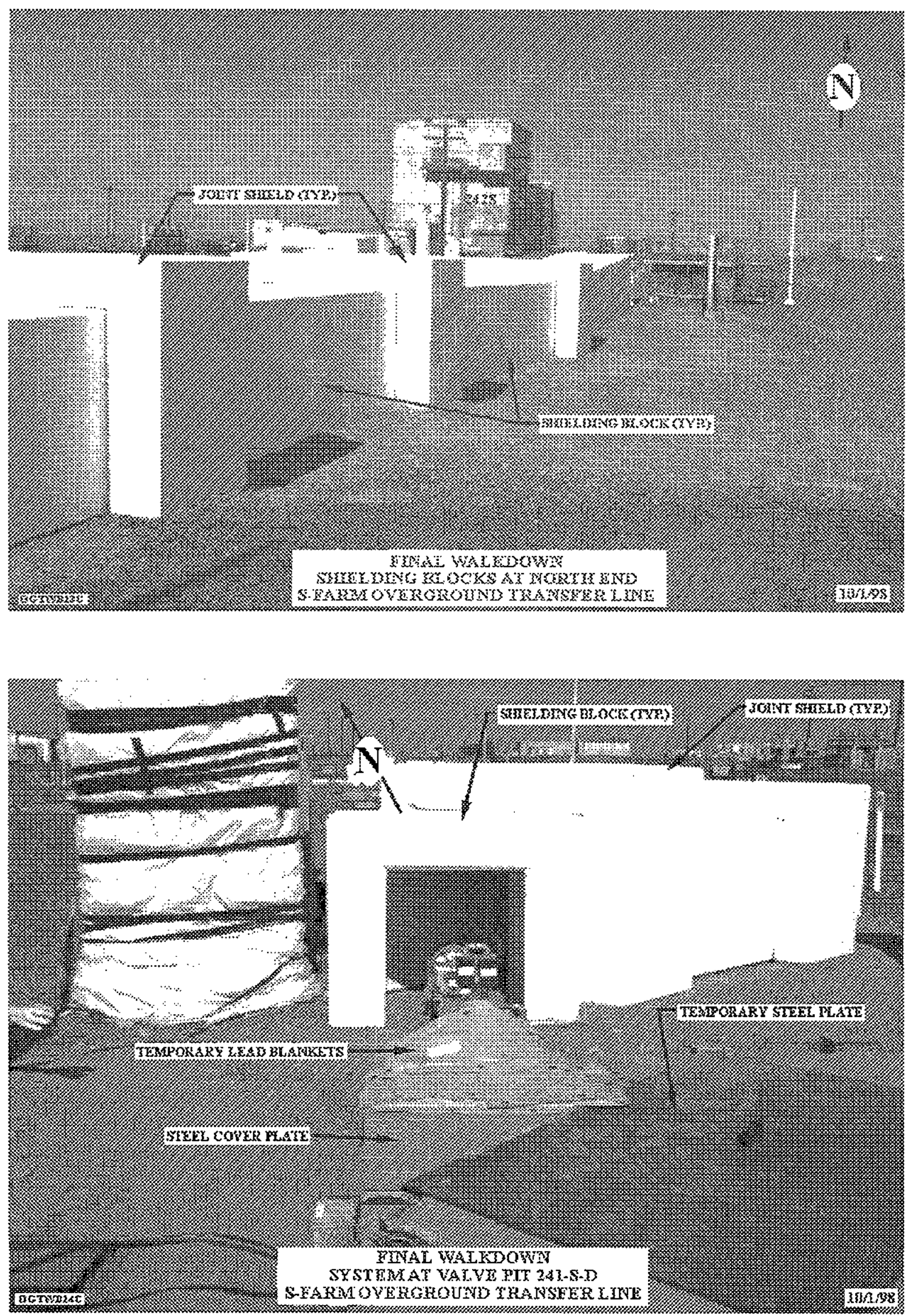
HNF-3477, Rev. 0
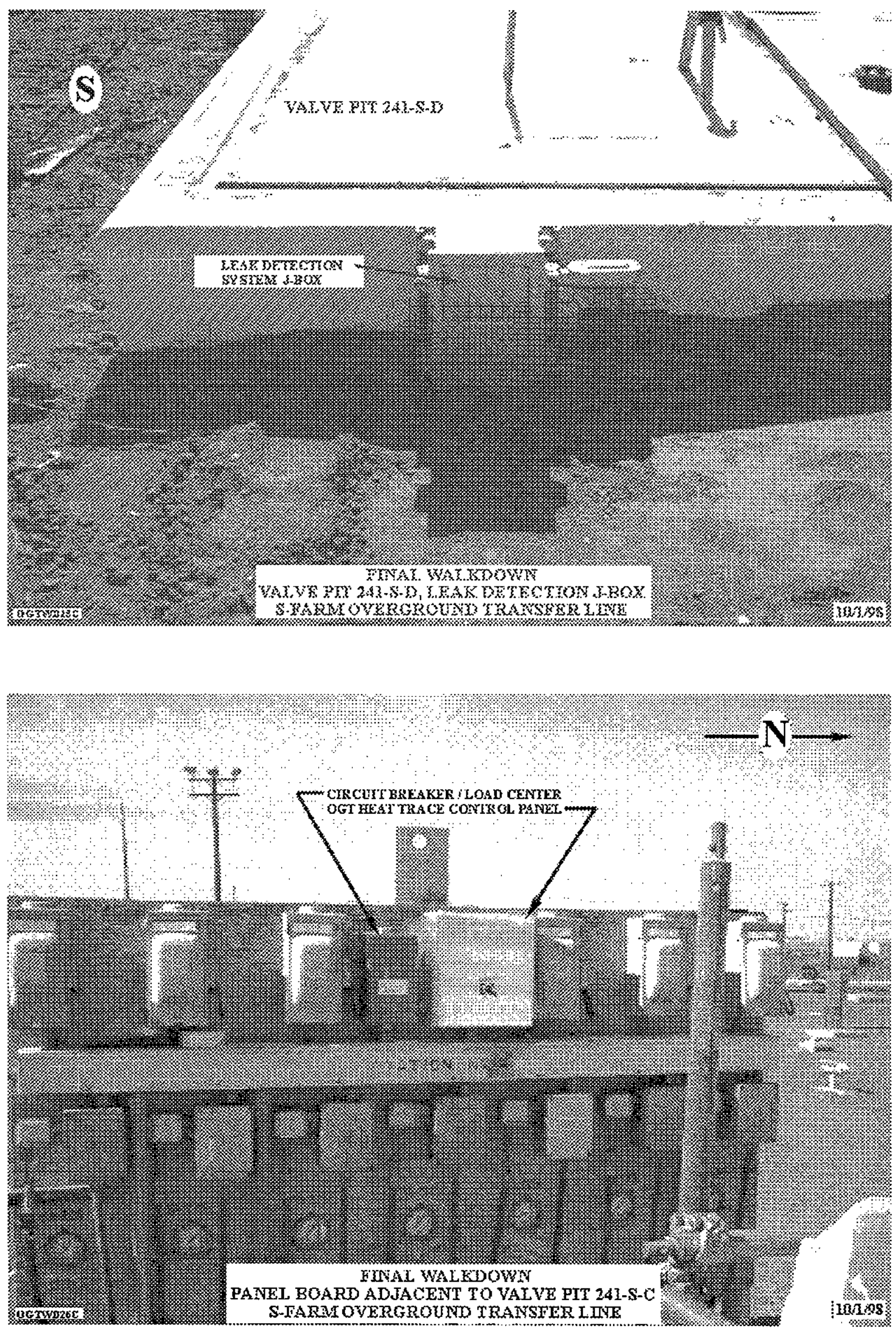
HNF-3477, Rev. 0

APPENDIX B

DRA WING LIST

B-0 


\section{REFERENCE DRAWING}

\section{TYPICAL OGT SYSTEM DRAWINGS \\ ORIGINAL DESIGN AND CONSTRUCTION, AVAILABLE 1995}

H-2-818279, sh. 1, Rev. 1 PIPING - PLAN, ELEVATION, AND DETAIL OVERGROUND TRANSFER LINE

H-2-818280, sh. 1, Rev. 0 PIPING - OVERGROUND TRANSFER SYSTEM ASSEMBLIES

H-2-818281, sh. 1, Rev. 1 PIPING - OVERGROUND TRANSFER SYSTEM - SUPPORT ASSEMBLIES

H-2-818281, sh. 2, Rev. 1 PIPING - OVERGROUND TRANSFER SYSTEM - SUPPORT ASSEMBLIES

H-2-818283, sh. 1, Rev. 0

INSTRUMENTATION - OVERGROUND TRANSFER SYSTEM - LOOP/ DETAIL DRAWING

H-14-100414, sh. 1, Rev. 0 CIVIL - CONCRETE SHIELDING - DETAILS

H-14-100414, sh. 2, Rev. 0 CIVIL - CONCRETE SHIELDING - DETAILS

H-14-100414, sh. 3, Rev. 0 CIVIL - CONCRETE SHIELDING - SPECIFICATION

\section{S-FARM OGT DRAWINGS \\ DEVELOPED AUGUST 1998 and REVISED JANUARY 1999}

H-2-829564, sh. 1, Rev. 1 CIVIL/PIPING - 241-S OGT PIPELINE - PLAN AND PROFILE

H-2-829564, sh. 1, Rev. $1 \quad$ CIVIL/PIPING - 241-S OGT PIPELINE - DETAILS

H-2-829565, sh. 1, Rev. 1 CIVIL/PIPING - 241-S OGT SHIELDING - PLAN AND

PROFILE

H-2-829565, sh. 1, Rev. 1 CIVIL/PIPING - 241-S OGT SHIELDING - DETAILS

H-2-829566, sh. 1, Rev. 0 ELECTRICAL/INSTM - S-FARM OGT PIPELINE - PLAN

H-2-829566, sh. 1, Rev. $0 \quad$ ELECTRICAL/INSTM - S-FARM OGT PIPELINE - DETAILS \& ELEMENTARY 


\section{TYPICAL EMERGENCY PUMPING \\ OGT SYSTEM DRAWINGS \\ AVAILABLE JANUARY 1999}

H-2-818280, sh. 1, Rev. 1 PIPING - EMER PUMPING, OGT SYSTEM - COMPONENTS / ASSEMBLIES

H-2-818280, sh. 2, Rev. 0 PIPING - EMER PUMPING, OGT SYSTEM - COMPONENTS / ASSEMBLIES

H-2-818281, sh. 1, Rev. 2 PIPING - EMER PUMPING, OGT SYSTEM - ALTERNATE SUPPORT ASSEMBLIES

H-2-818281, sh. 2, Rev. 2 PIPING - EMER PUMPING, OGT SYSTEM - SUPPORT ASSEMBLIES

H-2-818283, sh. 1, Rev. 2 PIPING - EMER PUMPING, OGT SYSTEM-ALTERNATE LOOP / DETAIL

H-14-100414, sh. 1, Rev. 0 CIVIL - CONCRETE SHIELDING - DETAILS

H-14-100414, sh. 2, Rev. 1 CIVIL - CONCRETE SHIELDING - DETAILS

H-14-100414, sh. 3, Rev. 1 CIVIL - CONCRETE SHIELDING - SPECIFICATION 
HNF-3477, Rev. 0

\section{APPENDIX C}

ENGINEERING CHANGE NOTICE LIST 


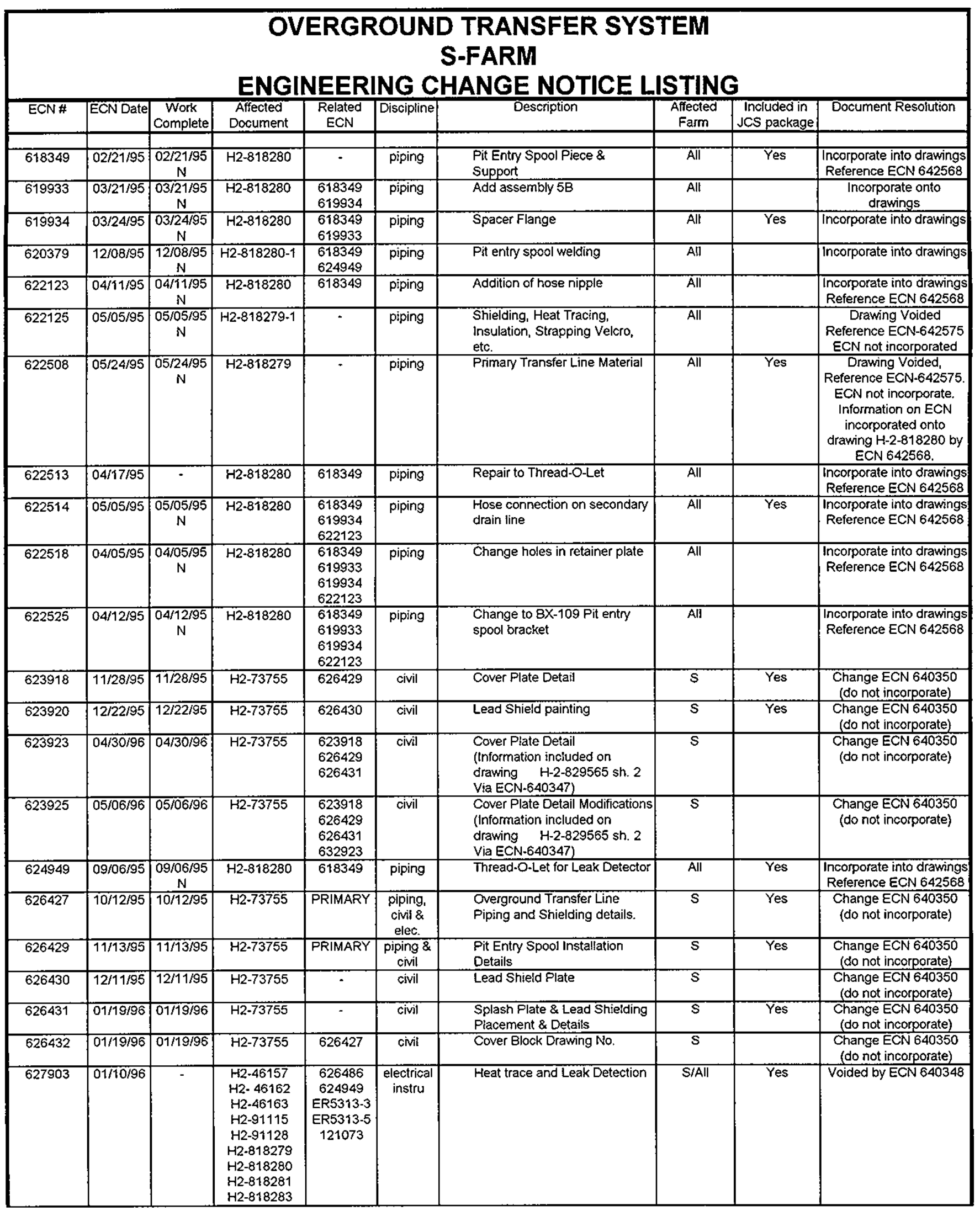




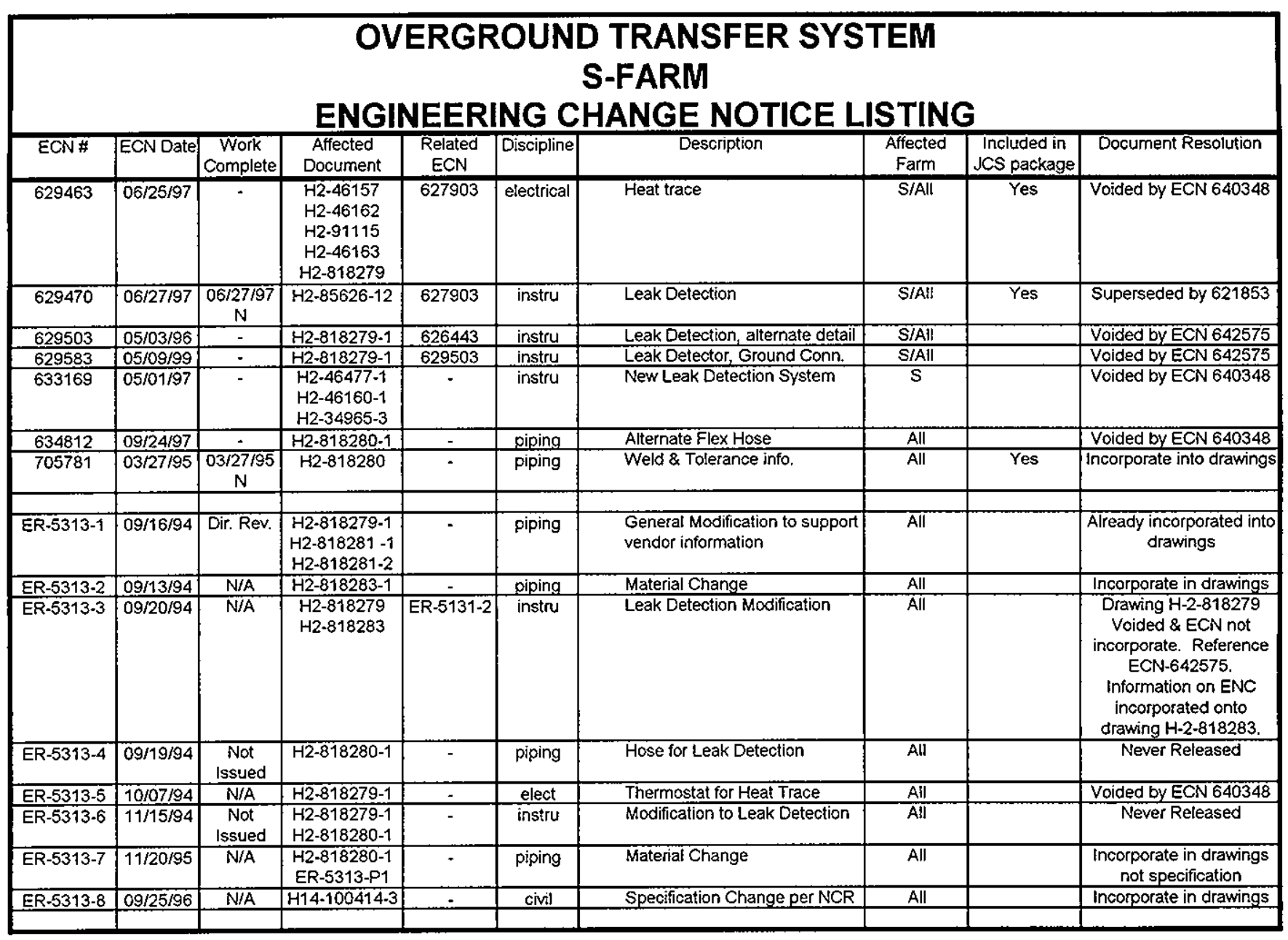




\section{APPENDIX D}

\section{CALCULATIONS}

Overground Transfer Encasement Pipe Stress Analysis

Concrete Shielding Blocks Stability and Pipe Supports,$\quad$ D $2-1$

Electrical Heat Trace Sizing $\ldots \ldots \ldots \ldots, D_{3} 31$ 
HNF-3477, Rev. 0

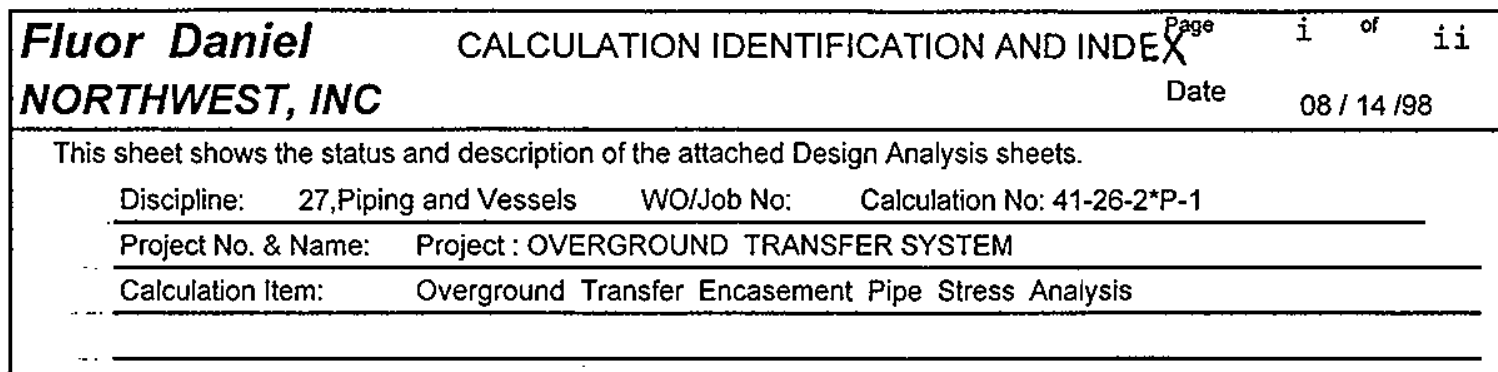

These calculations apply to:

Dwg. No. H-2-829564, Review No:4, 8/19/98

Dwg. No. $\mathrm{H}-2-8182820$ Rev. No. Rev. No.

Other (Study, CDR) Rev. No.

The status of these calculations is:

- Preliminary Calculations

$x \quad$ Final Calculations

- Check Calculations (On Calculation Dated

- Void Calculation (Reason Voided Incorporated in Final Drawings?

This calculation verified by independent "check" calculation?

Original and Revised Calculation Approvals:

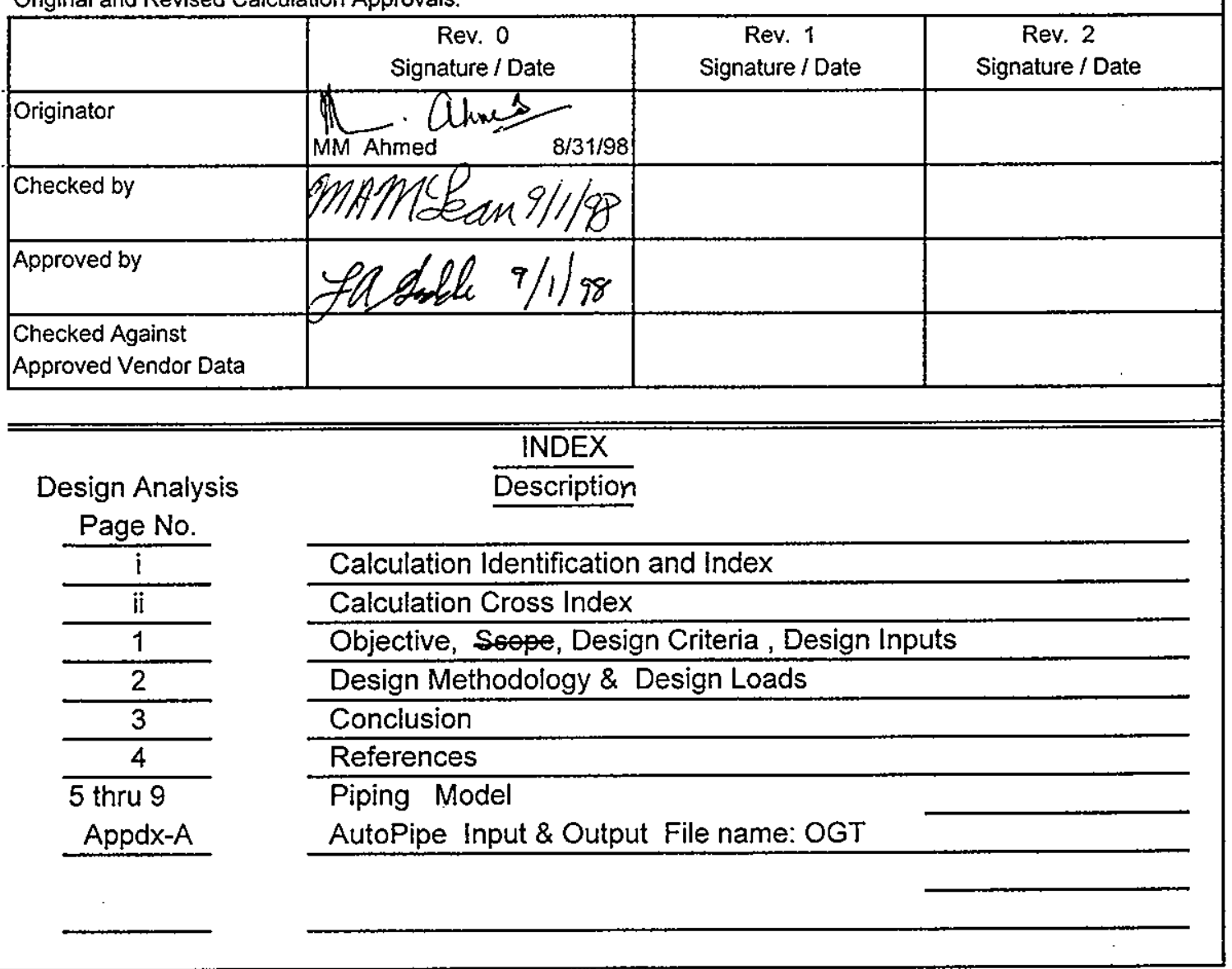




\begin{tabular}{|c|c|c|c|c|c|c|c|c|c|c|}
\hline \multicolumn{7}{|c|}{ CALCULATION CROSS INDEX (Typical) } \\
Subject Calculation No. 41-26-2P-1
\end{tabular}




\section{FLUOR DANIEL NW}

Client Numatec Hanford Inc

Subject

Over Ground Transfer line Encasement

Pipe Stress Analysis

Location $200 E$

\section{DESIGN ANALYSIS}

Wo/Job No.

Date: Aug 31, 98

Checked 9-1-98

Revised
Calc no: $41-26-2 * p-1$

Rev no: 0

Page no: 1 OF 9

\section{OBJECTIVE:}

The objectives of this analysis are:

1. Stress analyze the Over Ground Transfer (OGT) encasement piping system from

Valve Pit-D to Pit-B, as installed, for the sustain, thermal and seismic loads.

2. Compute the encasement pipe support loads which will be used to qualify the Support structures.

\section{DESIGN CRITERIA:}

1. Letter of Instruction, 7CF70-94-033, May 27, 1994.

2. ASME Code B31.3-1996 with B31.3b-1997 Addenda

3. Uniform Building Code - 1994.

4. HNF-SD-WM-BIO-001, Rev-0.

\section{DESIGN INPUTS:}

Pipe size and material

3" SCH 40, Pipe

Ref:1

ASTM A312 TP304L

Design Temperature

$200^{\circ} \mathrm{F}$

Ref:4

Design Pressure

90 psig

Safety Class

SC

Ref:1 
HNF-3477, Rev. 0

\section{FLUOR DANIEL NW}

Calc no: 41-26-2*P-1

Rev no: 0

Page no: 2 of 9

\section{DESIGN ANALYSIS}

WO/Job No.

Client Numatec Hanford Inc

Date: Aug 31, 98

Subject Over Ground Transfer line Encasement

Pipe Stress Analysis

Location 200E

Checked $9-/-98$

Revised

Filename:otg

By: M. M. Ahmed a

By: MAM

By:

\section{DESIGN METHODOLOGY:}

The Overground Transfer System piping is stress analyzed using the software program AutoPipe Ver-4.6. This program has been verified and validated in accordance with FDNW practice: 1342000960.

The 3" Sch 40 Overground Transfer System encasement pipe is modeled in the AutoPipe program per the as-built configuration (Ref: Dwg. H-2-829564 Rev-0). The transfer pipe originates from Valve Pit-D and terminates in to Valve Pit-B.

The first pipe support on the Pit-D wall is modeled as a rigid anchor in order to accomplish stability in the piping system. The pipe supports from the first anchor to Node point A14 (See Pages 5 thru 9 for piping model) are modeled as dead weight supports in order to provide flexibility for the pipe lateral movements. The rest of the supports are considered as Guide supports, which restrain pipe's vertical and lateral movements.

\section{DESIGN LOADS:}

The Overground piping system is subjected to following load cases.

\section{SUSTAIN LOADS:}

This category considers the impact of pipe weight, pipe components (Flanges) and pipe contents. The encasement pipe which contains the inner pipe is assumed to be full of water which makes the analysis conservative. The Sustain Load category also includes longitudinal pressure stress. The internal pressure is considered to be $90 \mathrm{psig}$, the design pressure of the inner pipe. The AutoPipe computes the sustain stress and checks against the ASME Code B31.3 allowable (Sh $=16700$ psi for SST pipe).

THERMAL LOADS:

The pipe thermal expansion (displacement) stress resulting due to temperature change from the ambient temperature of $70^{\circ} \mathrm{F}$ to the design temperature of $200^{\circ} \mathrm{F}$ is computed by the AutoPipe program in order to meet the ASME Code B.31.3 allowable.

\section{SEISMIC LOADS:}

The document HNF-SD-WM-BIO-001, Rev-0 (Ref:4) categorizes the OGT piping system as Safety Class system, which requires $0.19 \mathrm{~g}$ response spectra dynamic analysis. 
HNF-3477, Rev. 0

\section{FLUOR DANIEL NW}

Calc no: 41-26-2*P-1

Rev no: 0

Page no: 3 of 9
Client Numatec Hanford Inc

Subject Over Ground Transfer line Encasement

Pipe Stress Analysis

Location $200 E$

\section{DESIGN ANALYSIS}

WO/Job No.

Date: Aug 31, 98

Checked $4-1-98$

Revised
Filename:otg

By: M. M. Ahmed

By: $M A M$

By:

However, in lieu of dynamic analysis, static equivalent methodology with a seismic acceleration of $0.225 \mathrm{~g}$ is used which yields conservative analysis. The UBC (Ref:3) methodology is used to compute the horizontal seismic acceleration factor as specified in FDNW Practice: 1342151217 (Ref: 6 ). The seismic accelerations factors are applied in two (X \& Z) horizontal directions.

SEISMIC LATERAL FORCE:

$$
F p=\text { Z.I.Cp.Wp Ref:3, page 2-22 }
$$

Since $\quad F p=m . a \quad \& \quad W p=m . g$

Therefore $\quad a=$ Z.I.Cp.g

Where $\quad Z=0.2$ for seismic zone-2B

Ref:3, Table 16-1

$I=1.5$ for Hazardous facilities

Ref:3. Table 16-K

$\mathrm{Cp}=0.75$ for Equipment \& Piping

Ref:3, Table 16-O

$a=(0.2) \cdot(1 \cdot 5) \cdot(0.75) \cdot g$

$a=0.225 .9$

WIND LOADS:

The wind loads are not considered in the analysis because of the following reasons:

Since the pipe is approximately 3 feet above the ground, the wind loads are insignificant, The seismic loads are more critical compared to wind loads. The wind loads and seismic loads need to be treated separately in accordance with the requirements of the ASME Code B31.3. Also the OGT system design calls for shielding blocks to be placed around the piping system, which will minimize the wind effects.

\section{CONCLUSION:}

Review of the AutoPipe results indicate that pipe stresses in sustain, thermal and seismic categories meet the ASME Code B31.3 requirements. However the following issues need to be addressed. 


\section{FLUOR DANIEL NW}

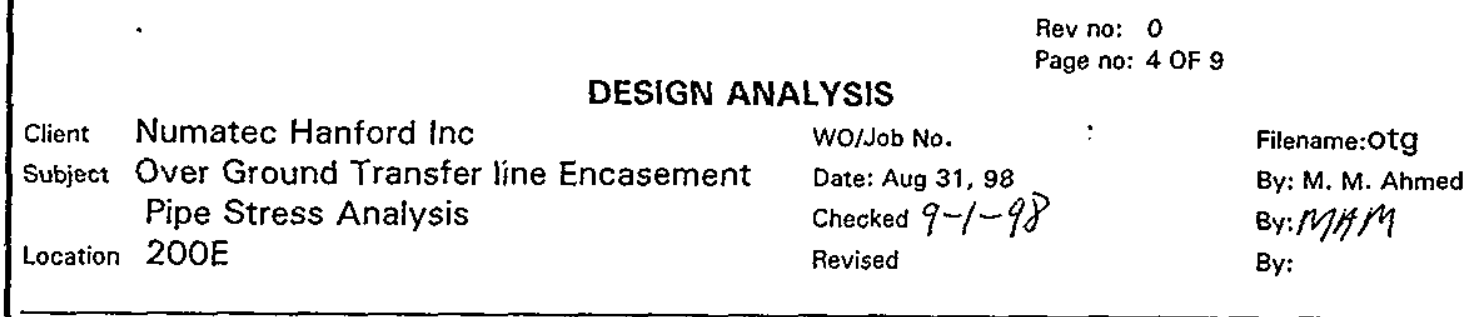

1. The analysis considers the first pipe support located on the Valve Pit-D concrete wall as a Rigid Anchor. The existing support at this location (Clamping the pipe between a steel plate $\&$ concrete wall with bolts $\&$ nuts) needs, to be modified to restrain pipe forces in all six directions (three forces $\&$ three moments). This can be accomplished either by welding the pipe to the plate or tightening the nuts.

2. After the first anchor (discussed above), the next five pipe supports should be dead weight (Gravity) supports. The pipe should not be laterally restrained at these Locations.

3. The rest of the pipe supports should be Guide supports, restraining the pipe's vertical and lateral movements.

4. The pipe should be free to expand at the terminal point where it enters Valve Pit-B. The existing support at this location can be modified to have enough gap between The pipe and plate so as to allow free pipe expansion.

5. The pipe support loads listed on the pages A11 \& A12 of the appendix-A shall be used for pipe support structural analysis.

\section{REFERENCES:}

1. Letter of instruction: 7CF70-94-033, May 27,1994.

2. ASME Code B31.3-1996 with B31.3b-1997 Addenda.

3. Uniform Building Code (UBC) -1994

4. WHC Document: HNF-SD-WM-BIO-001, REV.0

5. AutoPipe program Version 4.6 by Rebis Company.

6. FDNW Practice No: 134215 1217, Publication date: April 25,1997. Design Loads For Facilities.

7. Drawings: H-2-829564, Rev-O (Review No:4, dated 8-19-98)

$\mathrm{H}-2-818280$ Rev-O


HNF-3477, Rev. 0
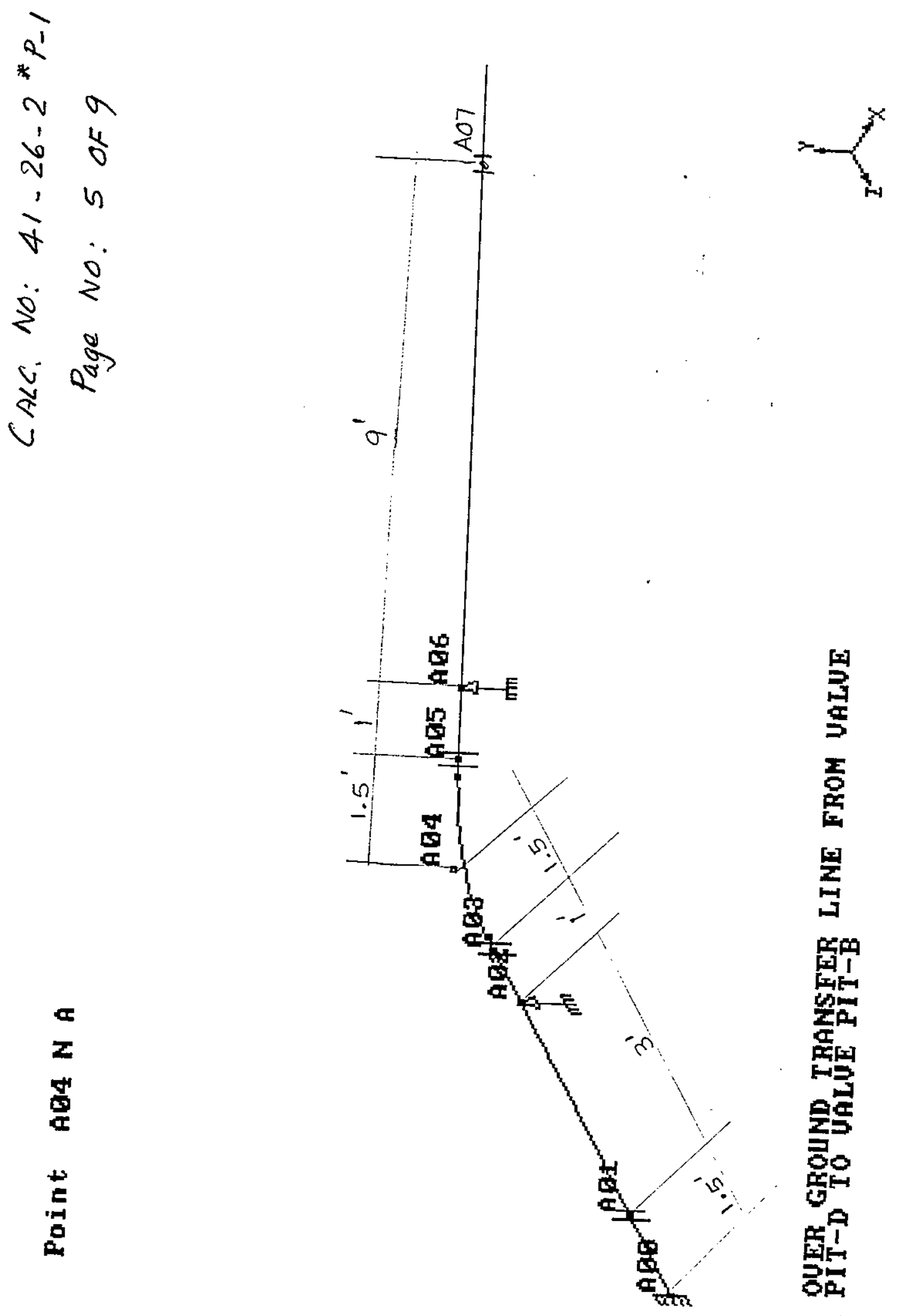
HNF-3477, Rev. 0

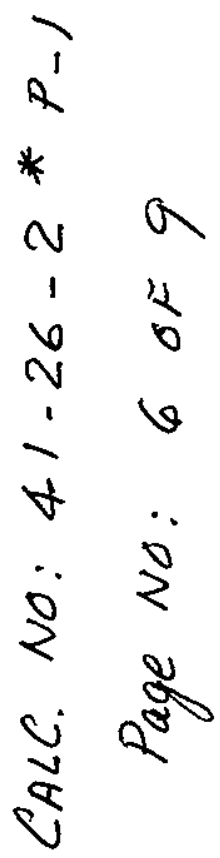

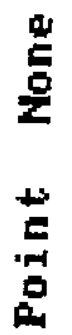
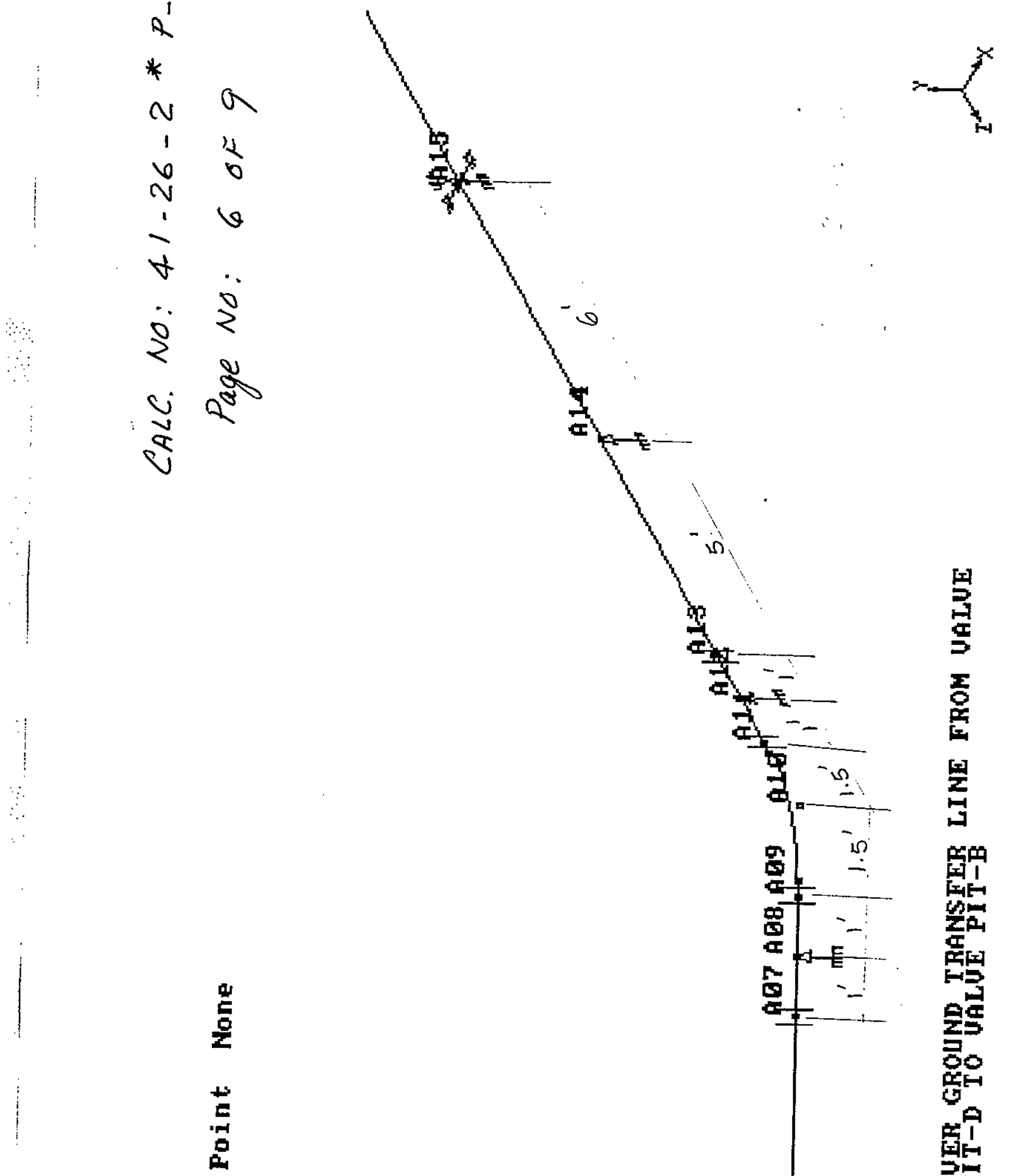

亚

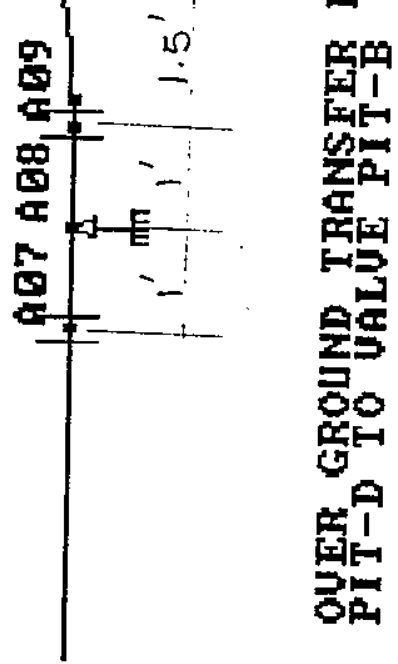




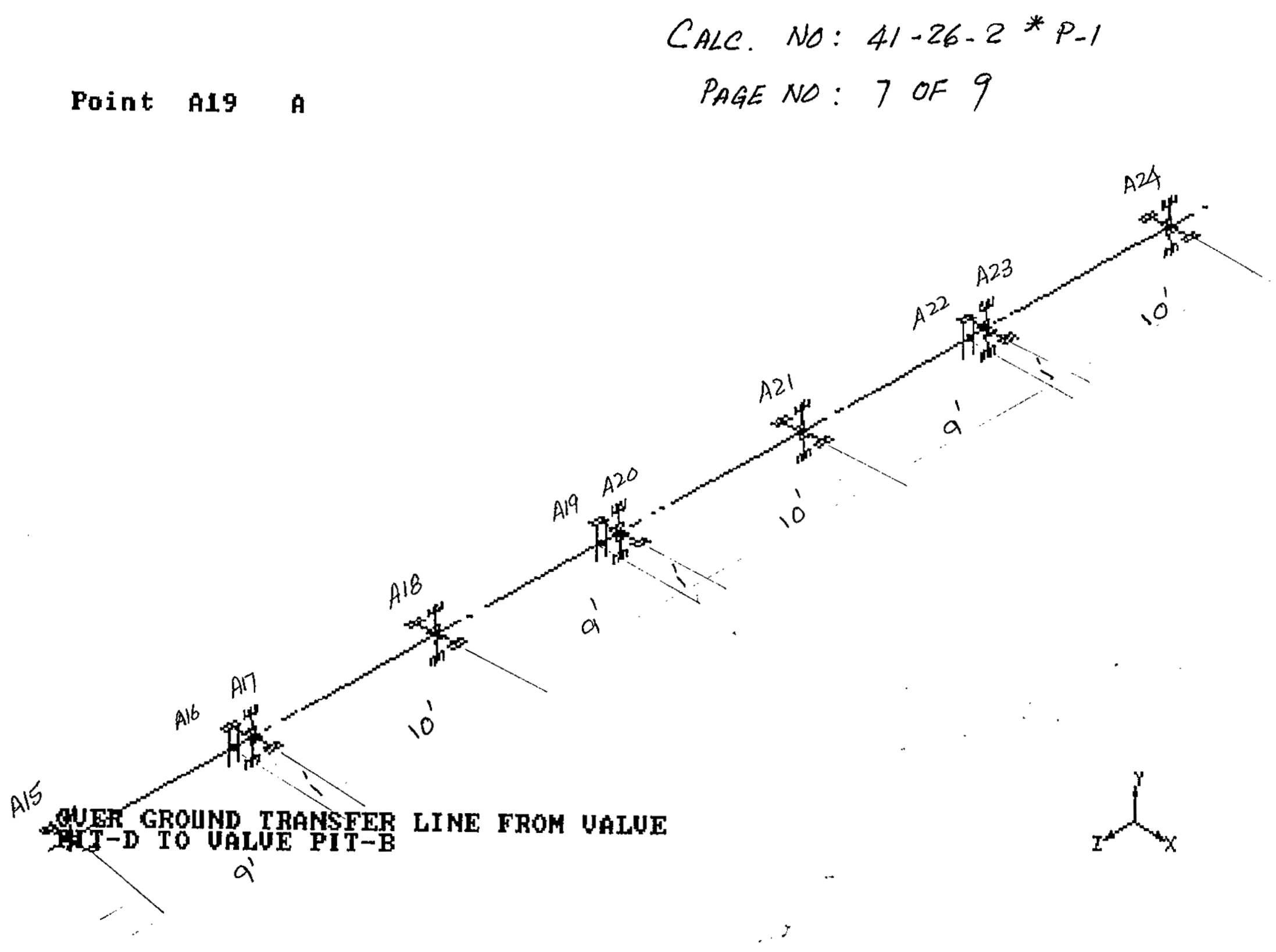




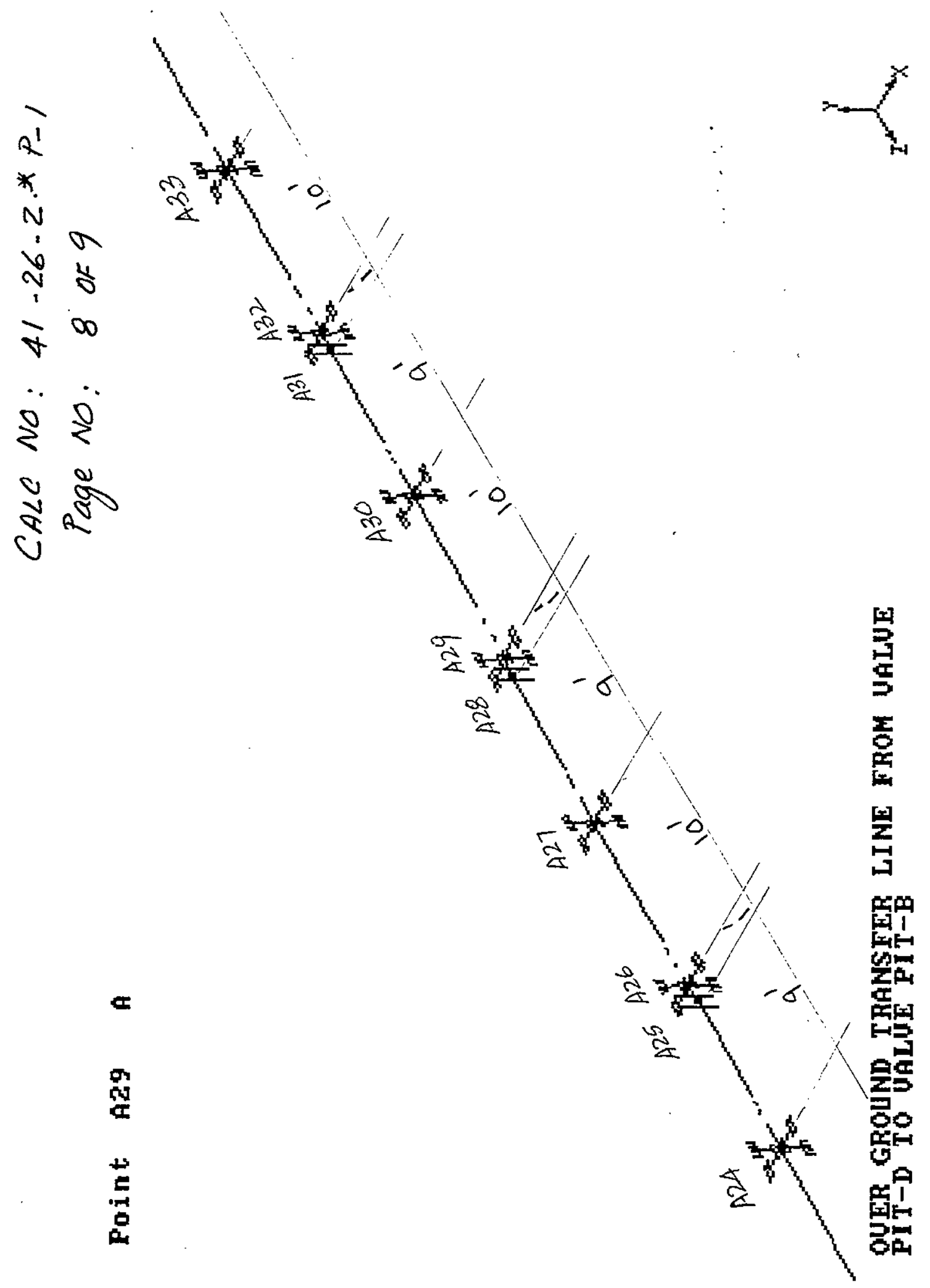


HNF-3477, Rev. 0

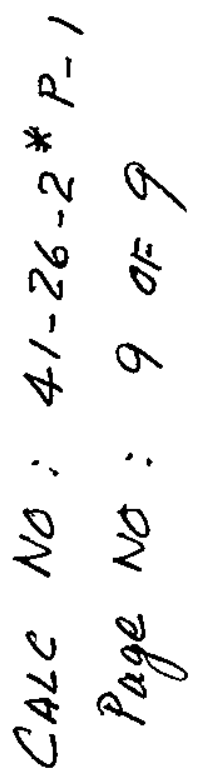

$x$

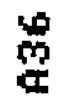

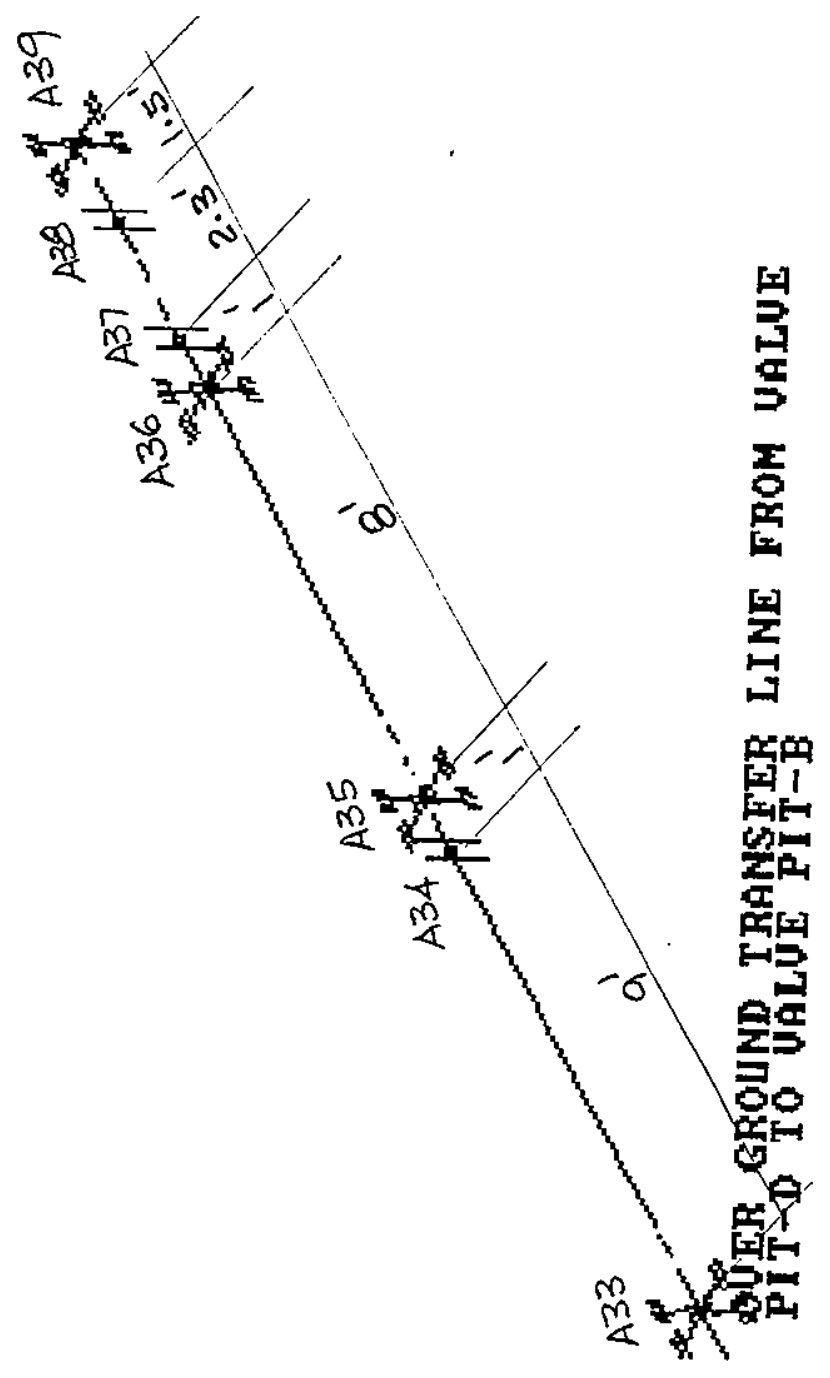


HNF-3477, Rev. 0

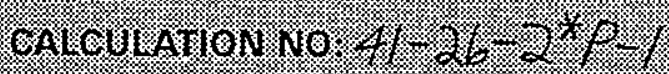

$\mathrm{REV}: 0$

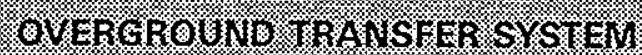

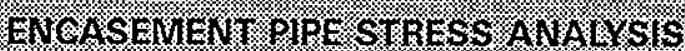

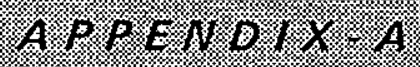

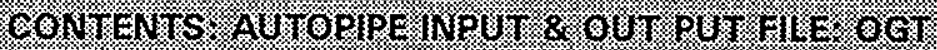




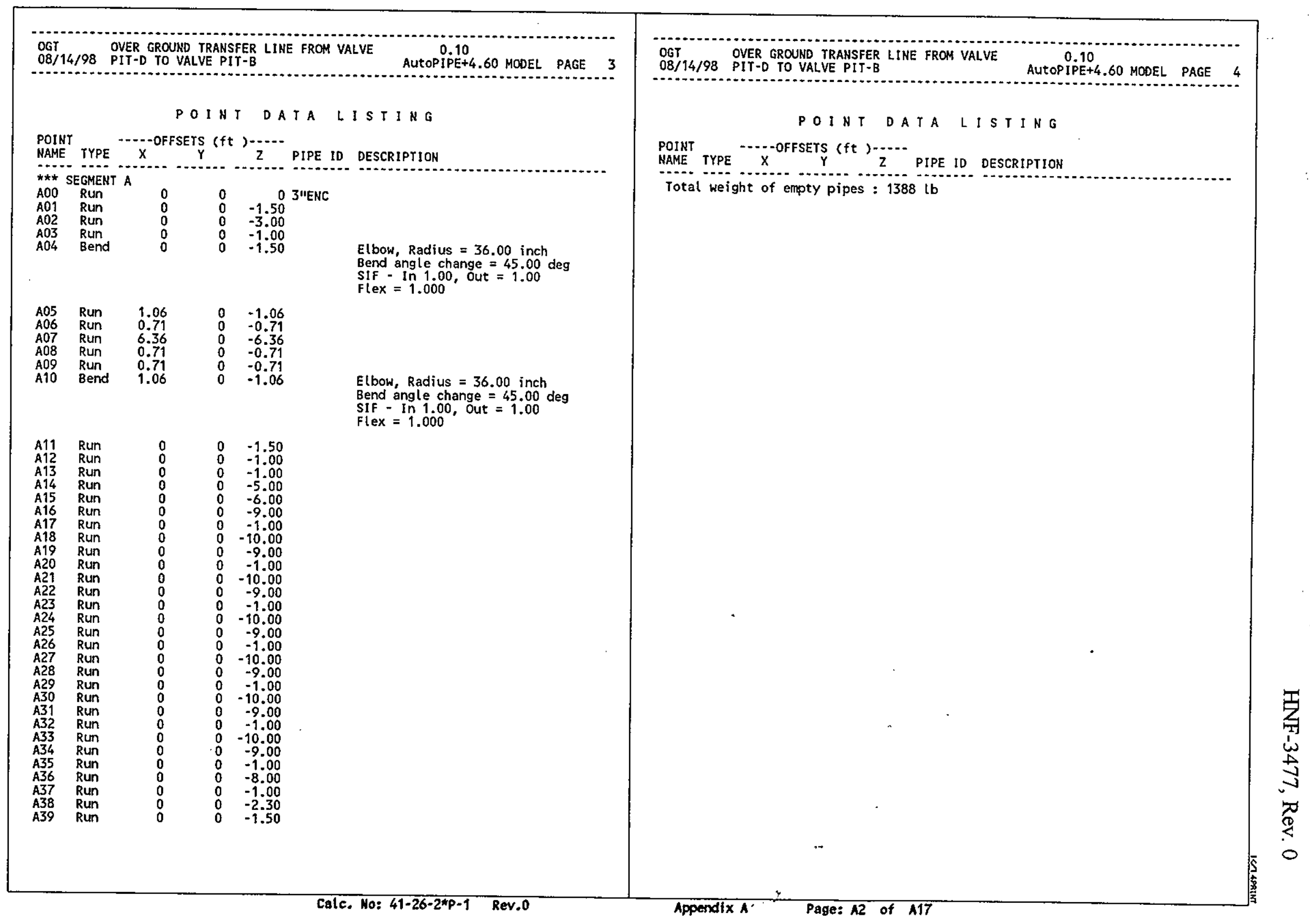




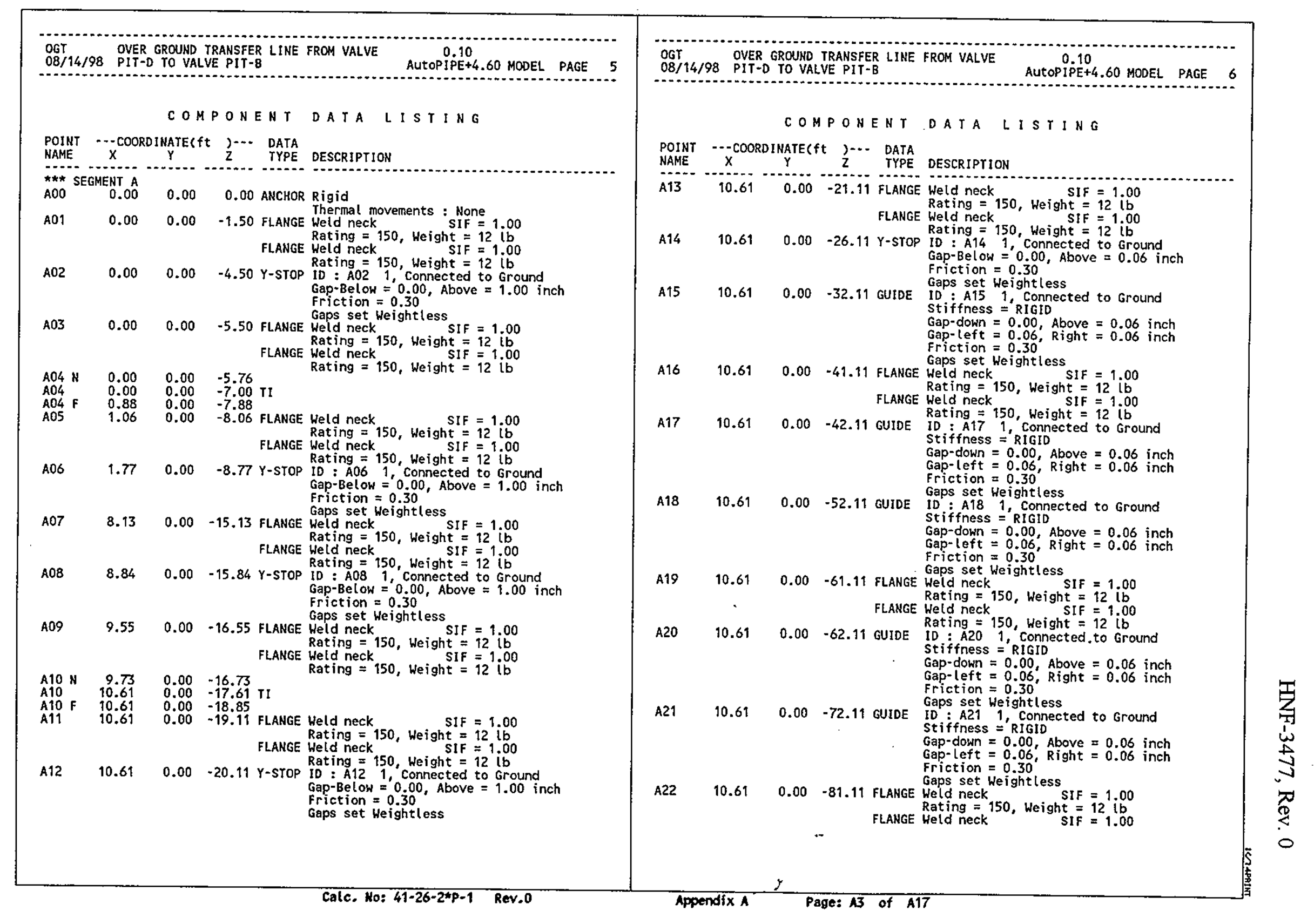




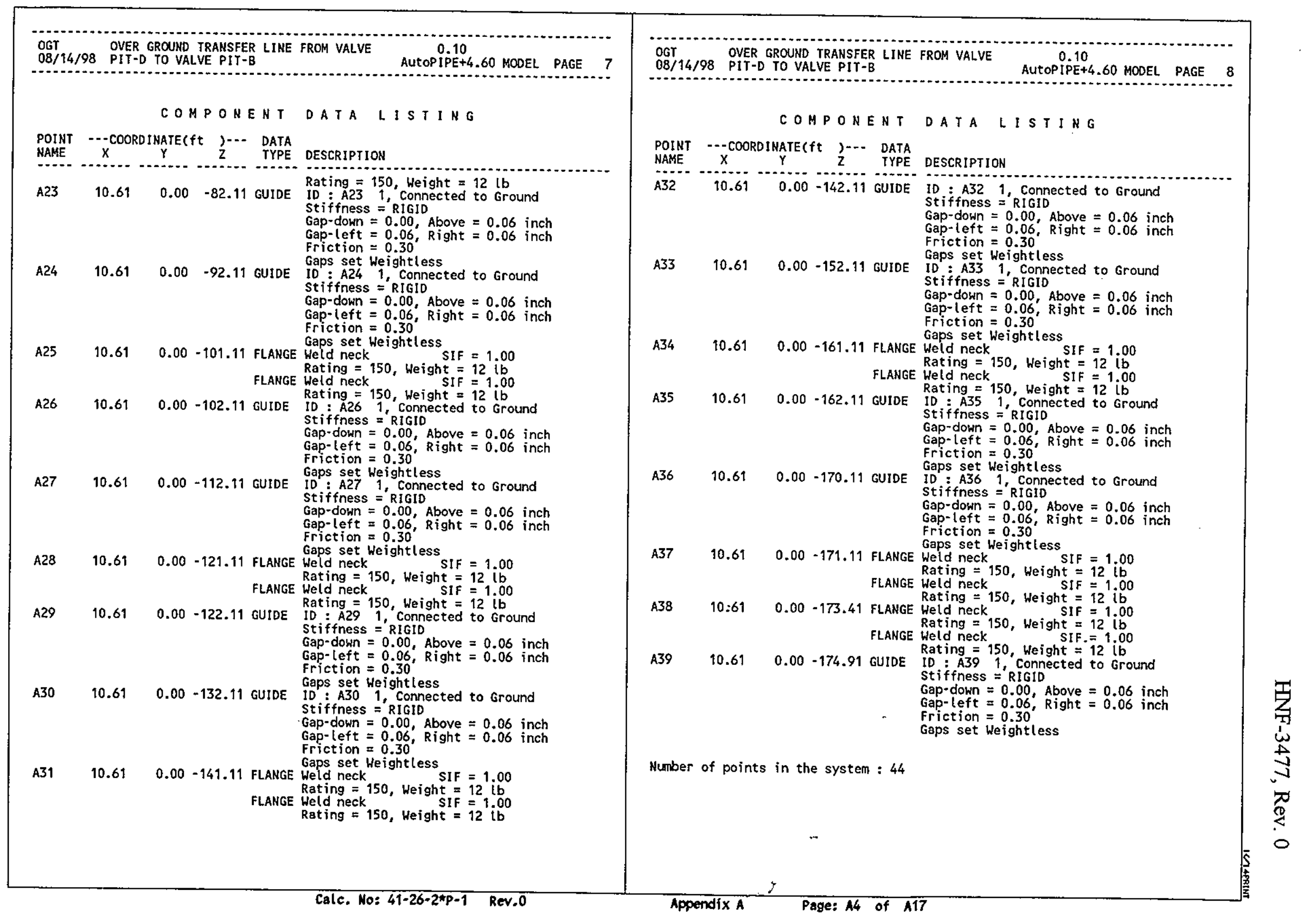




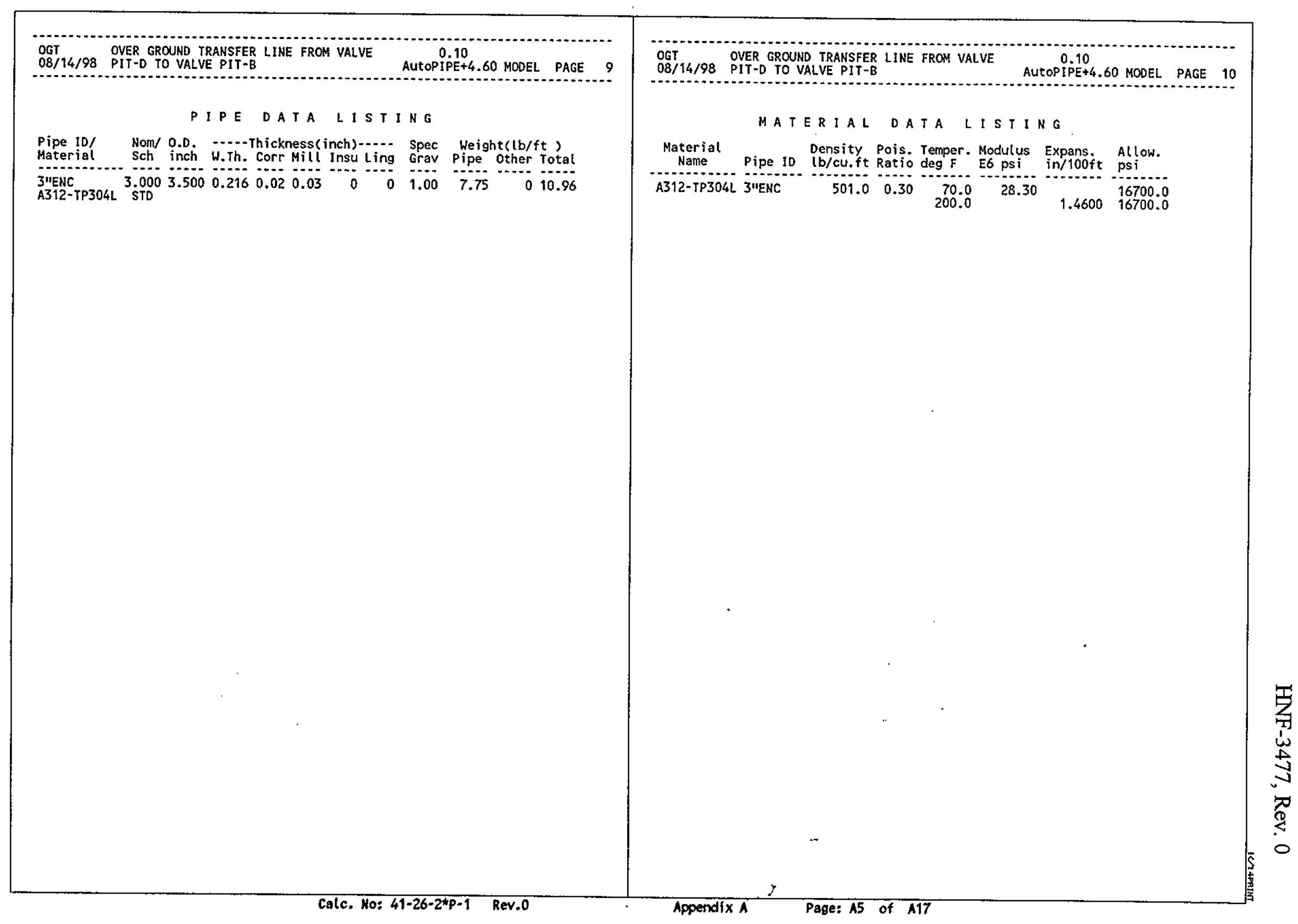




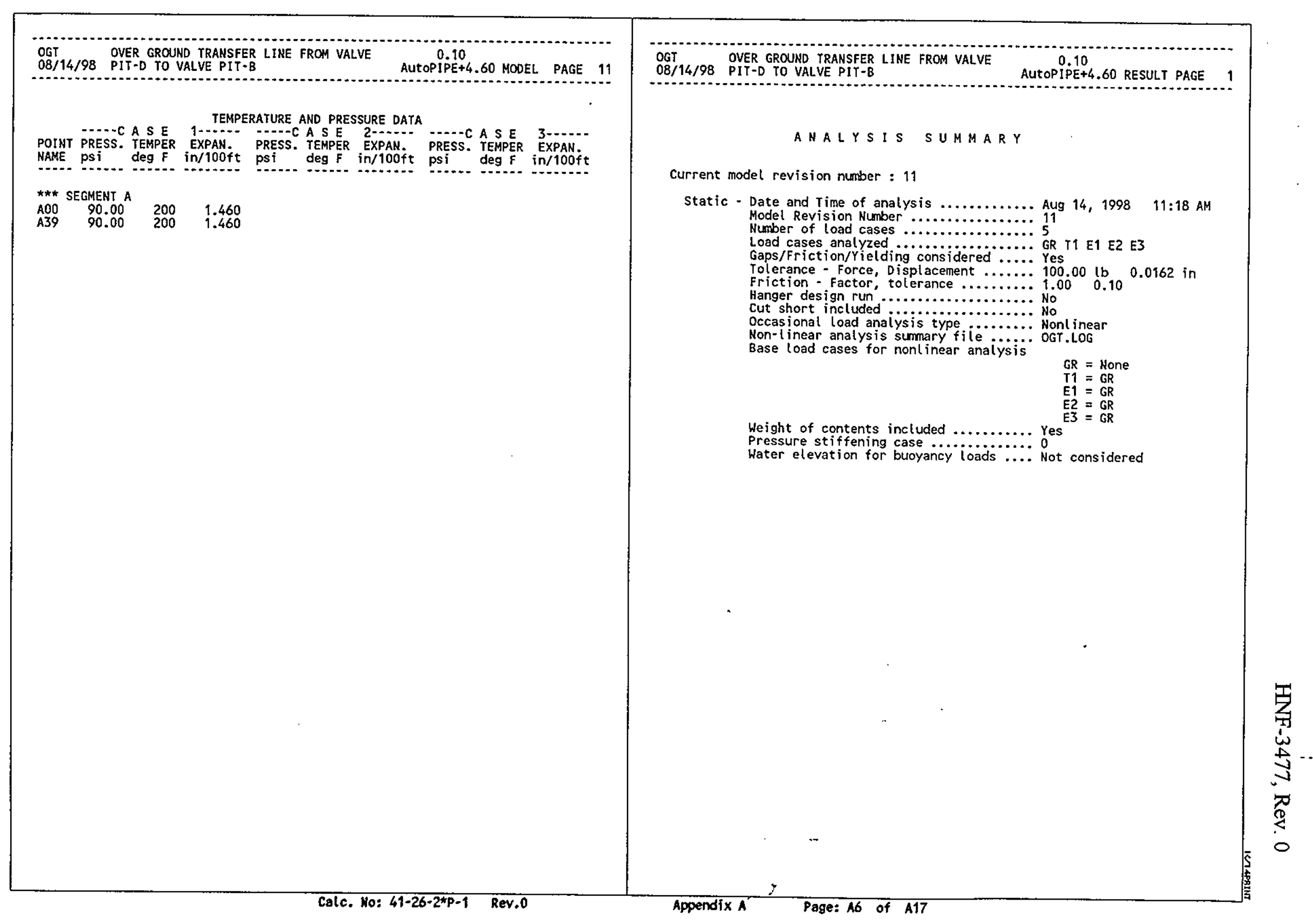




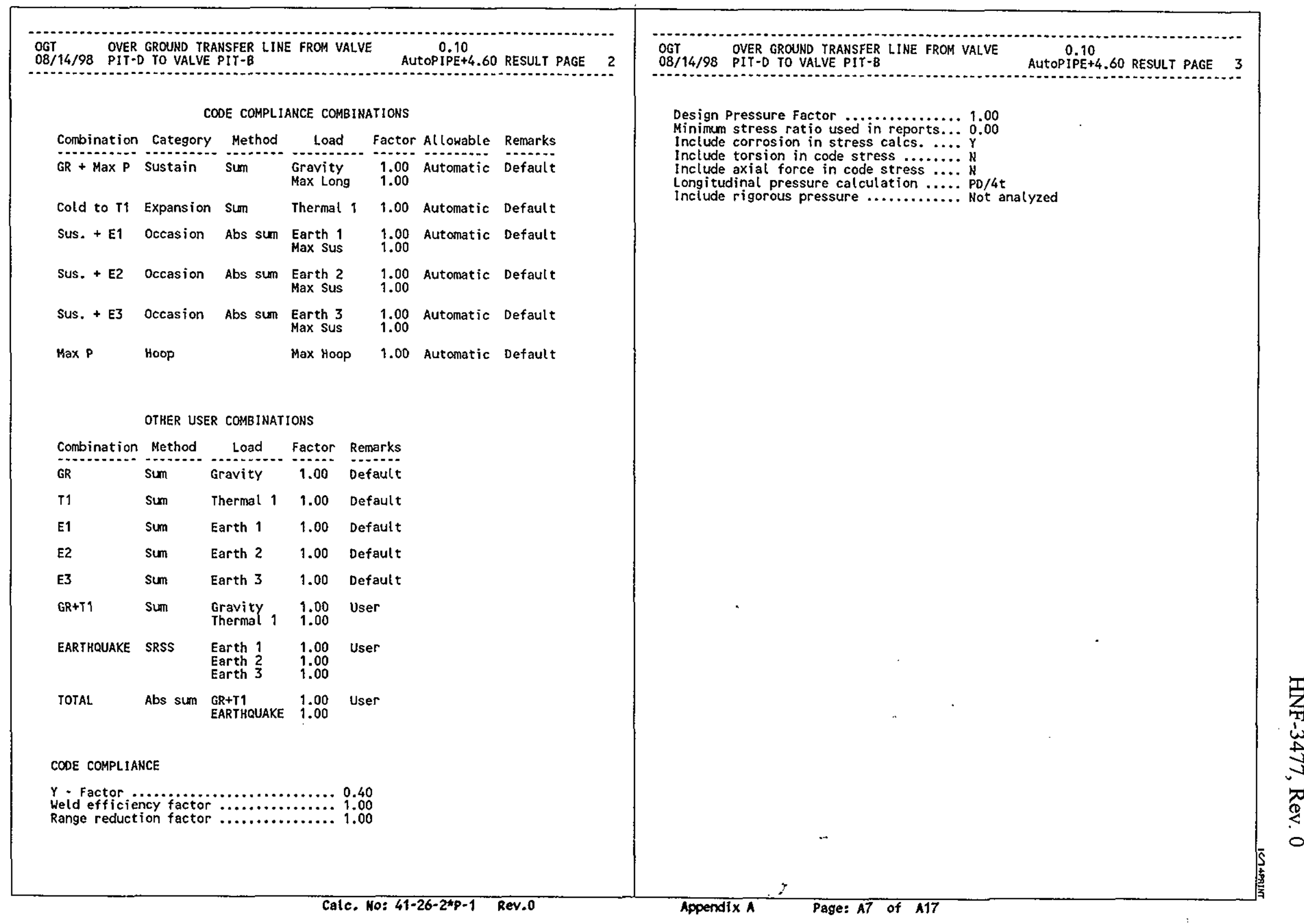




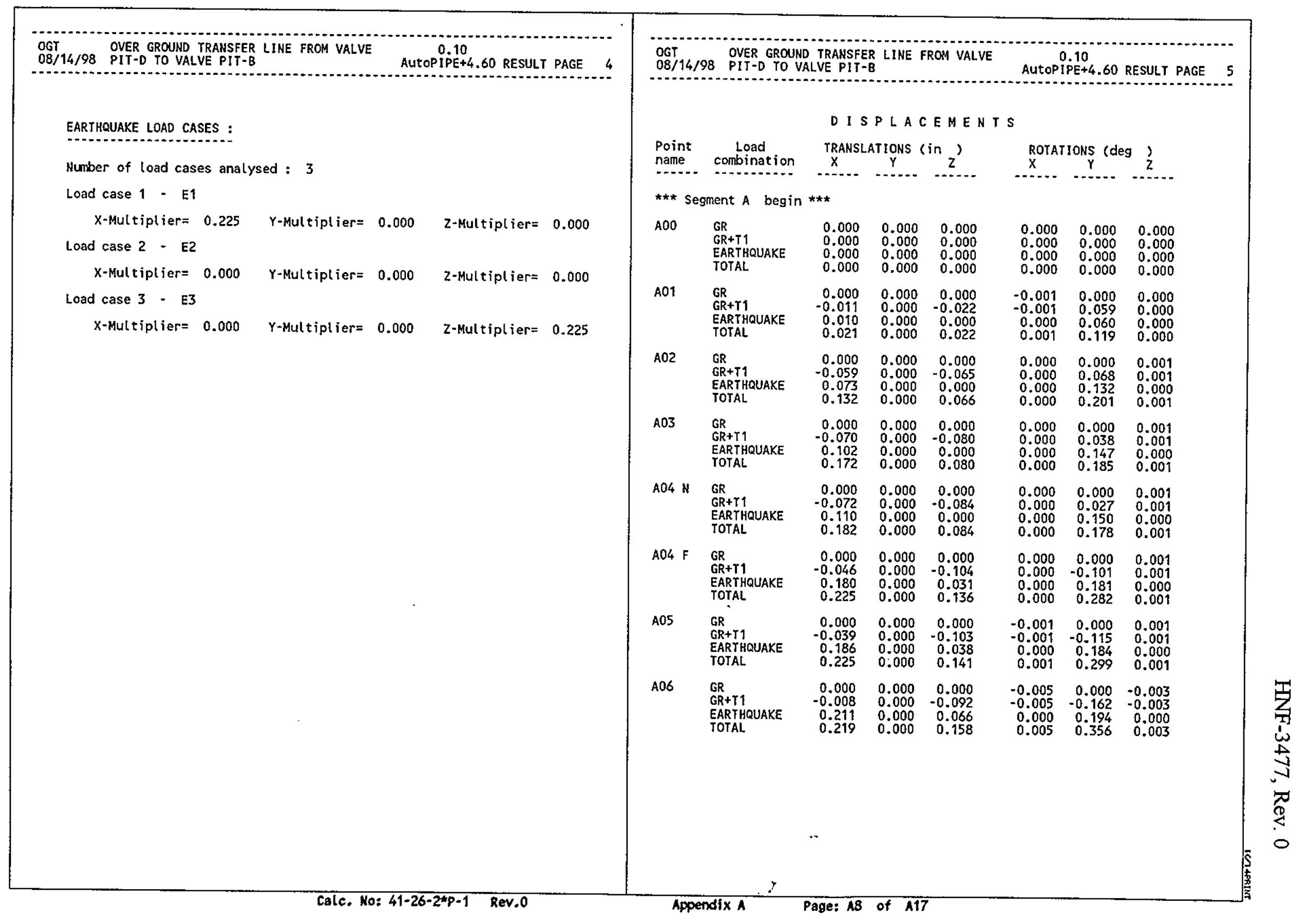




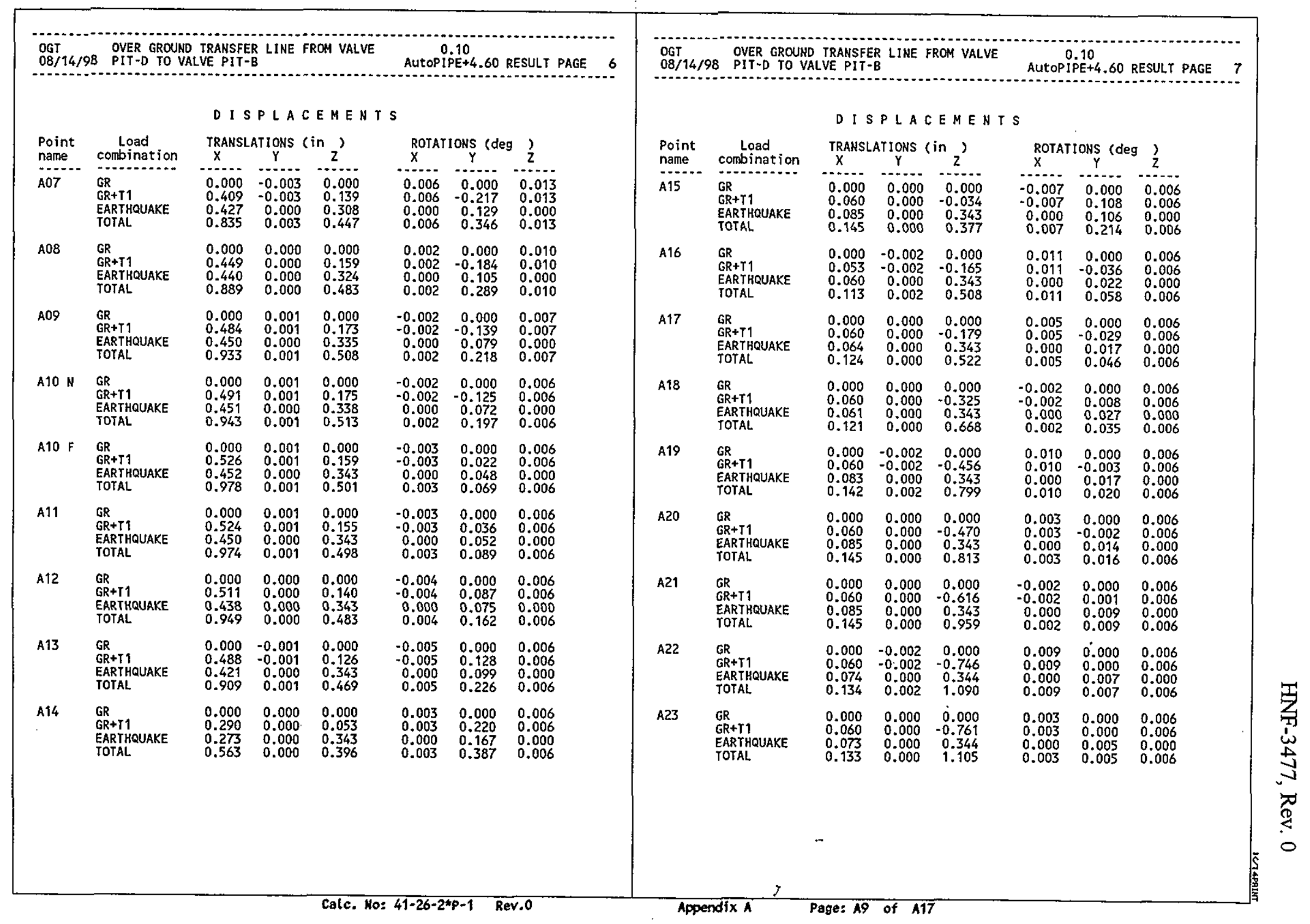




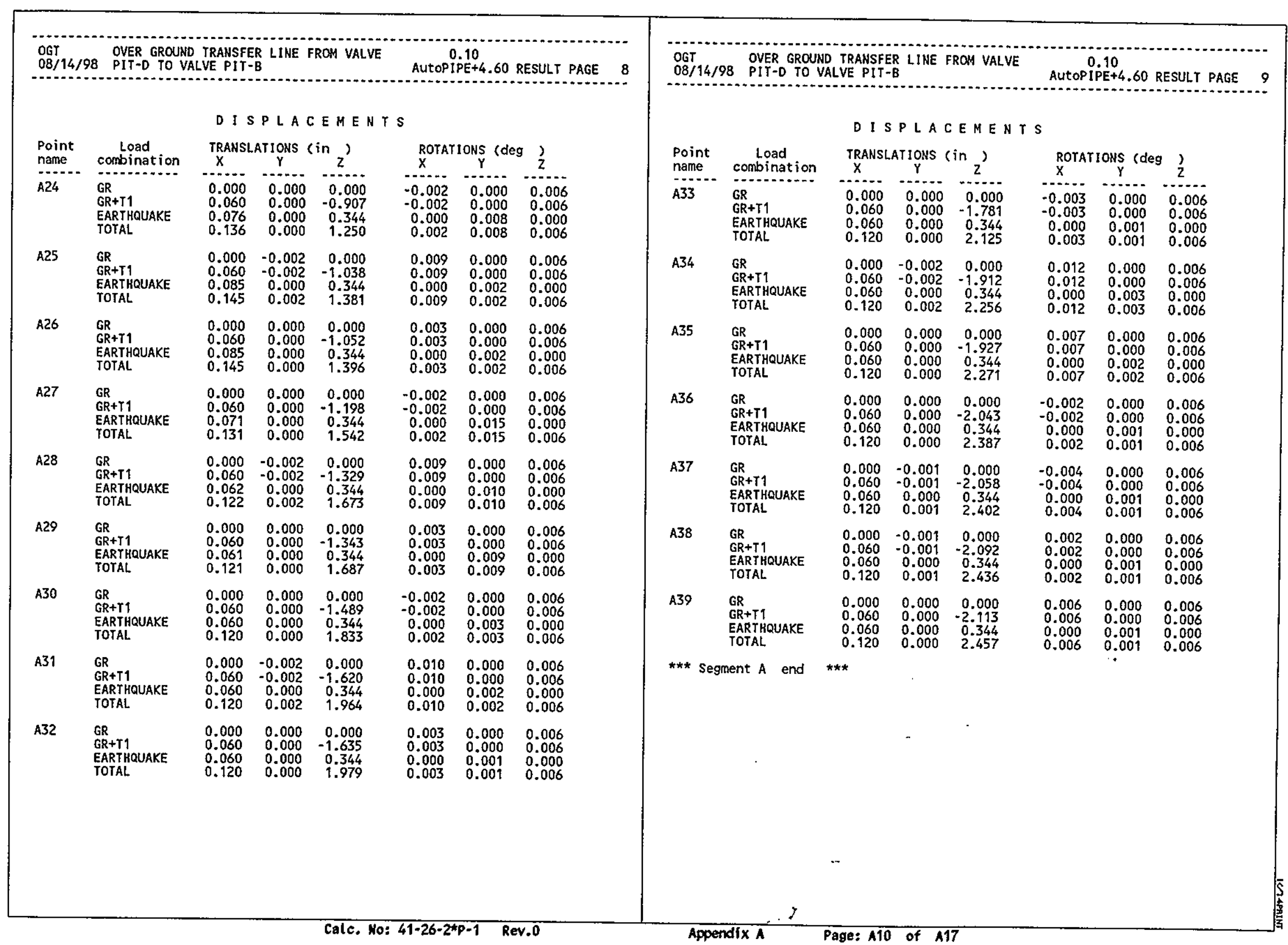




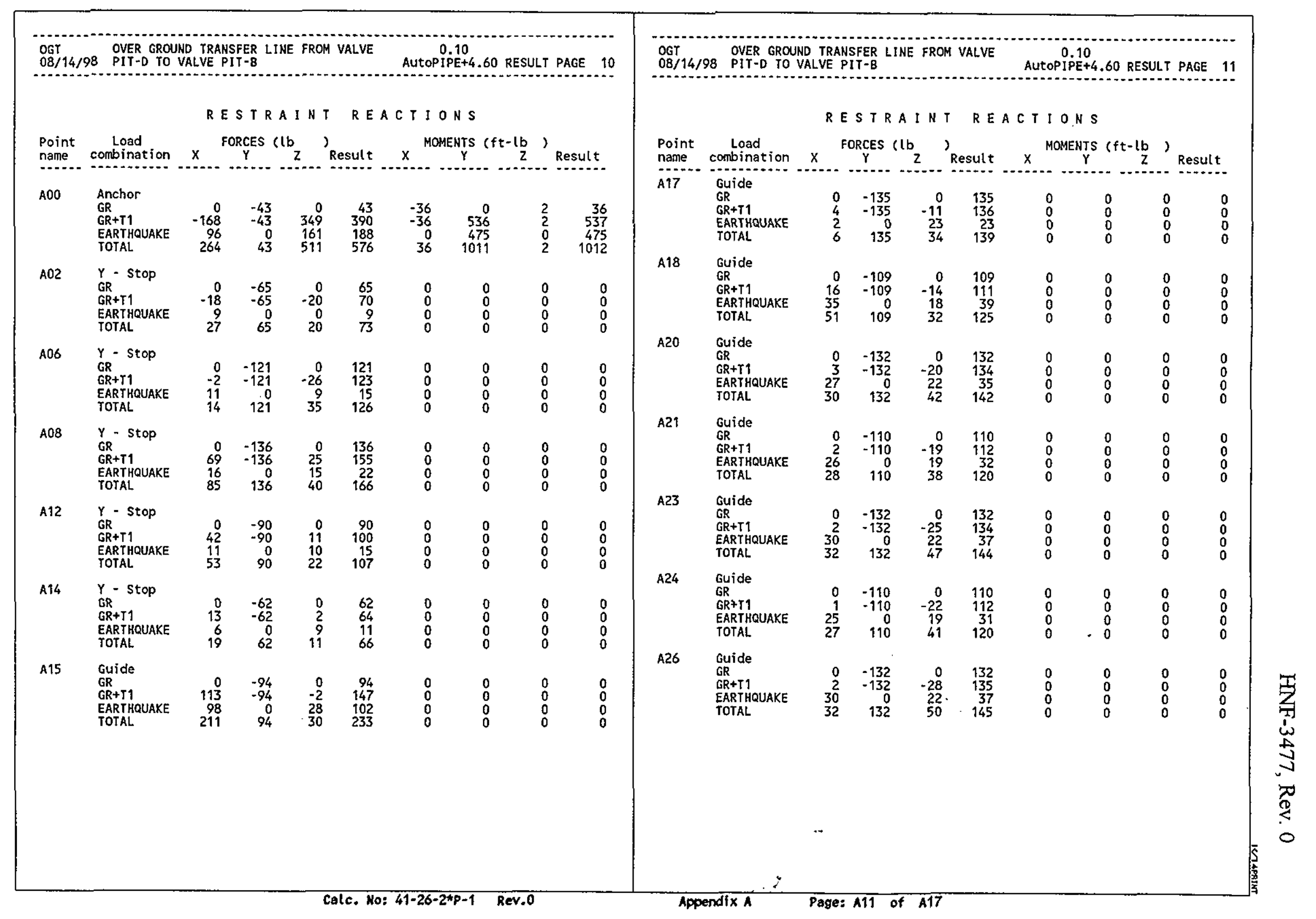




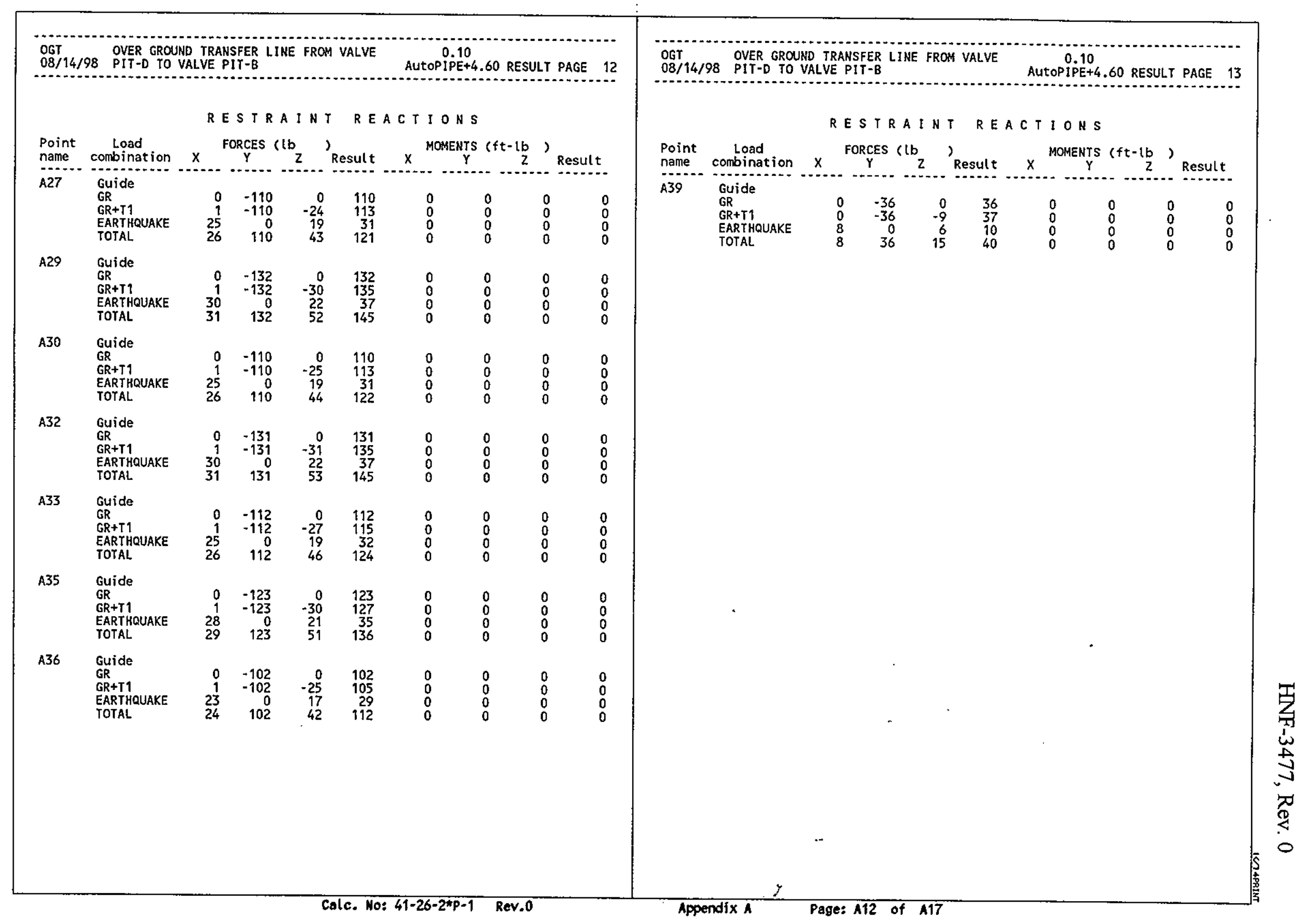




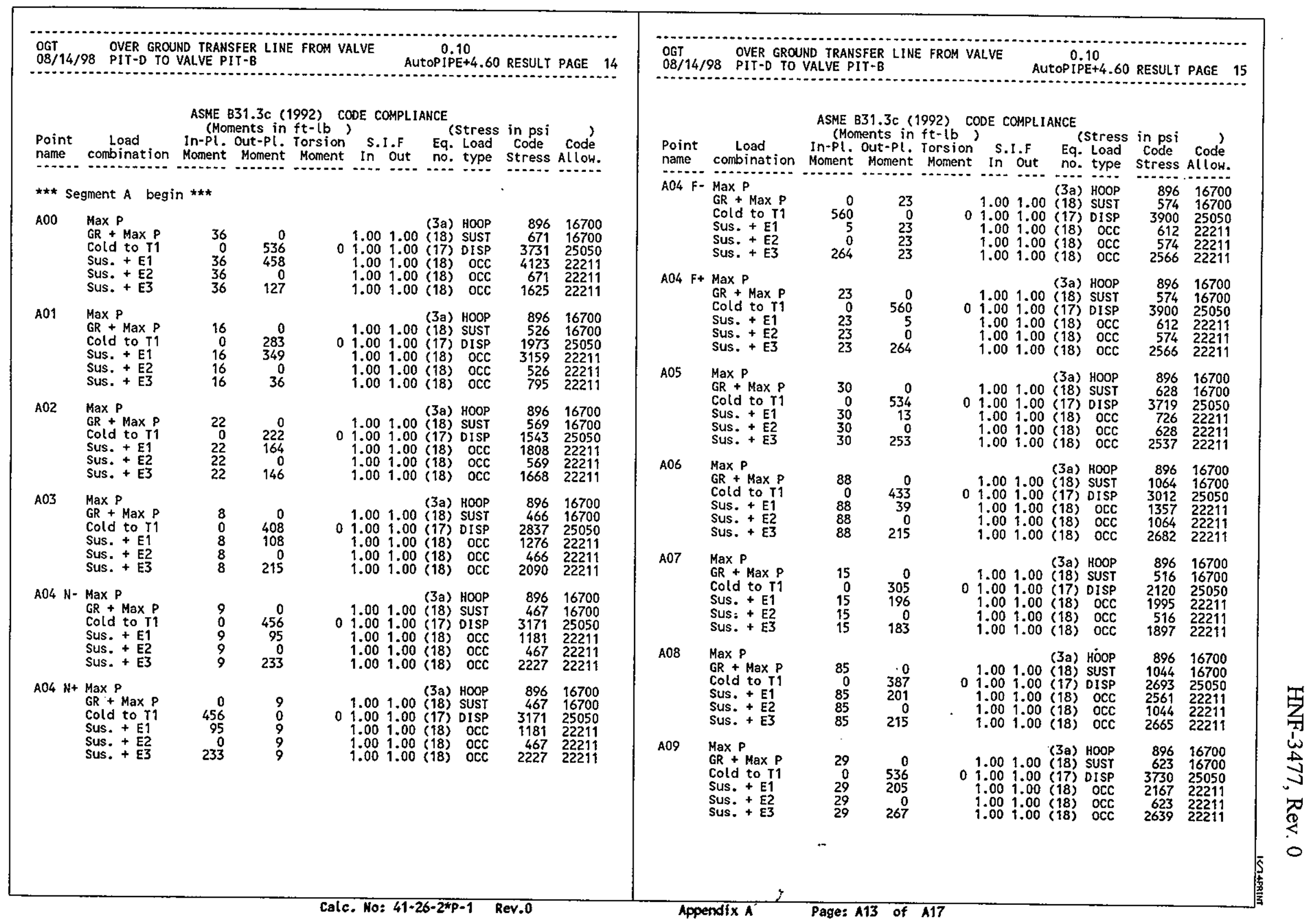




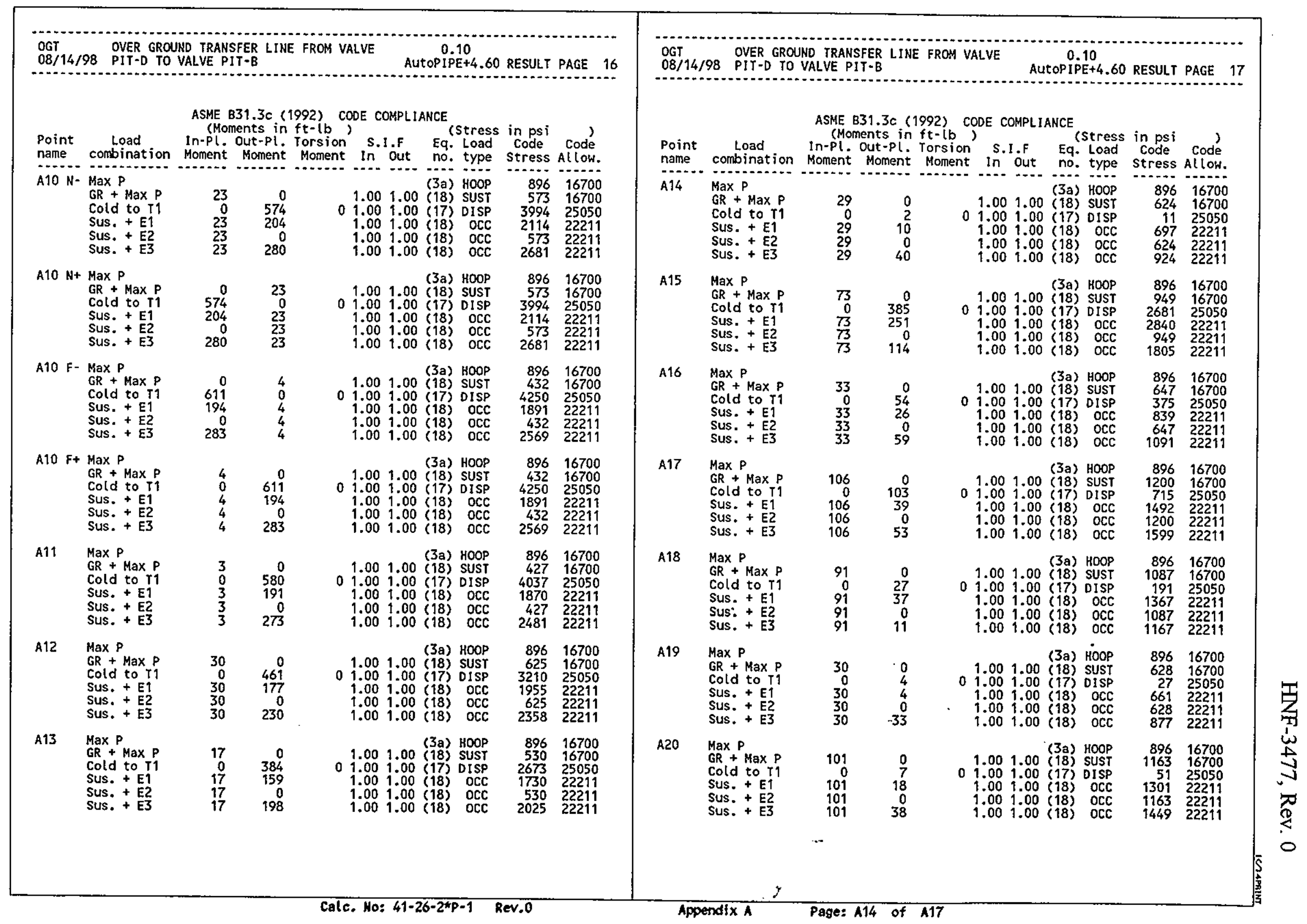




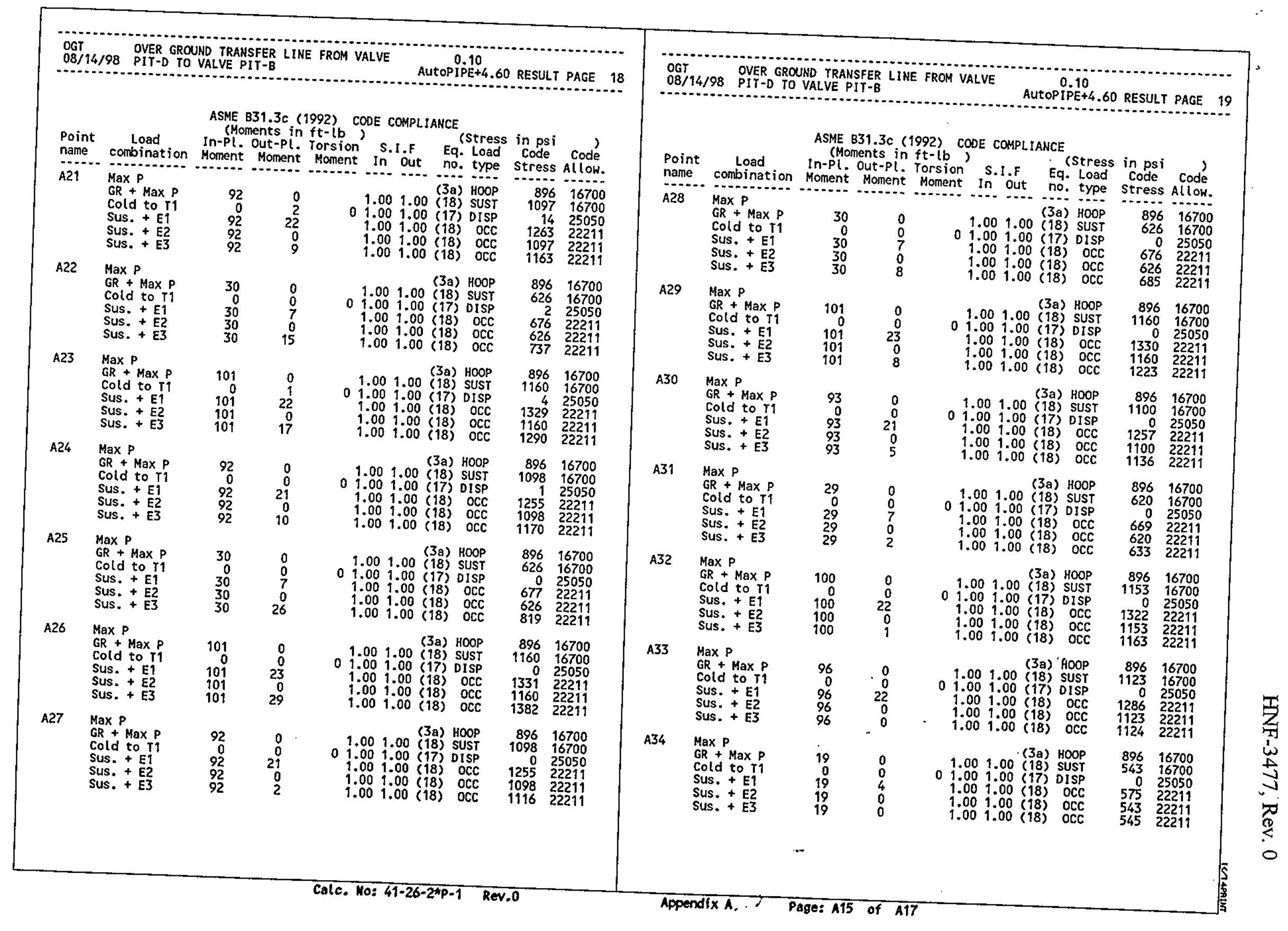




\begin{tabular}{|c|c|c|c|c|c|c|c|c|c|c|c|}
\hline \multicolumn{12}{|c|}{$\begin{array}{l}\text { OGT } \\
\text { O8/14/98 PVER GROUND TRANSFER LINE FROM VALVE VALE PIT-B }\end{array}$} \\
\hline $\begin{array}{l}\text { Point } \\
\text { name }\end{array}$ & $\begin{array}{c}\text { Load } \\
\text { combination }\end{array}$ & $\begin{array}{l}\text { ASME B3 } \\
\text { Mome } \\
\text { In-PL. } \\
\text { Moment }\end{array}$ & $\begin{array}{l}331.3 \mathrm{c} \text { (1 } \\
\text { nents in } \\
\text { Out-pit. } \\
\text { Moment }\end{array}$ & $\begin{array}{l}\text { 1992) CODE COMPLIANCE } \\
\text { ft-lb } \\
\text { Torsion S.l.F Eq. ER Los } \\
\text { Moment in Out no. type }\end{array}$ & $\begin{array}{l}\text { in psi } \\
\text { code } \\
\text { stress }\end{array}$ & $\begin{array}{l}\text { code } \\
\text { Allow. }\end{array}$ & \multirow{2}{*}{\multicolumn{5}{|c|}{ Maximum displacements (in) }} \\
\hline A35 & $\begin{array}{l}\text { Max } P \\
\text { GR }+ \text { Max } P \\
\text { Cold to } T^{T 1} \\
\text { Sus. }+E 1\end{array}$ & $\begin{array}{r}88 \\
0 \\
88\end{array}$ & $\begin{array}{r}0 \\
0 \\
20\end{array}$ & 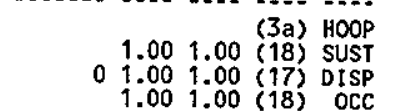 & $\begin{array}{r}896 \\
1065 \\
1215\end{array}$ & $\begin{array}{l}16700 \\
16700 \\
25050 \\
2720\end{array}$ & & & & & \\
\hline & $\begin{array}{l}\text { Sus. + E2 } \\
\text { Sus. + E3 }\end{array}$ & $\begin{array}{l}88 \\
88\end{array}$ & $\begin{array}{l}0 \\
0\end{array}$ & $\begin{array}{l}1.001 .00(18) \text { occ } \\
1.001 .00(18) \text { OCC }\end{array}$ & $\begin{array}{l}1065 \\
1067\end{array}$ & $\begin{array}{l}22211 \\
22211\end{array}$ & \multirow{2}{*}{$\begin{array}{c}\text { Maximum X } \\
\text { Maximum } \\
\text { Maximum } Z \\
\text { Max. total } \\
\text { Maximum rotations (deg) }\end{array}$} & \multirow{2}{*}{$\begin{array}{r}0.978 \\
-0.003 \\
2.457 \\
2.460\end{array}$} & \multirow{2}{*}{$\begin{array}{l:l}\text { Point }: A 10 F \\
\text { Point } & A 07 \\
\text { Point } & \text { A39 } \\
\text { Point } & \text { A39 }\end{array}$} & \multirow{2}{*}{\multicolumn{2}{|c|}{$\begin{array}{l}\text { Load Comb. : TOTAL } \\
\text { Load Comb.: GR } \\
\text { Load comb: TOAAL } \\
\text { Load comb.: TOTAL }\end{array}$}} \\
\hline A36 & $\begin{array}{l}\text { Max } P \\
\text { GR }+ \text { Max } P \\
\text { Cold to } P 1 \\
\text { Sus. + E1 } \\
\text { Sus. + E2 } \\
\text { Sus. + E3 }\end{array}$ & $\begin{array}{r}51 \\
0 \\
51 \\
51 \\
51\end{array}$ & $\begin{array}{r}0 \\
0 \\
11 \\
0 \\
0\end{array}$ & 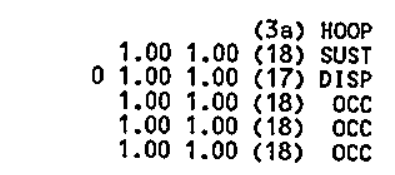 & $\begin{array}{r}896 \\
786 \\
0 \\
873 \\
786 \\
787\end{array}$ & $\begin{array}{l}16700 \\
16700 \\
25050 \\
22211 \\
2211 \\
22211\end{array}$ & & & & & \\
\hline A37 & $\begin{array}{l}\text { Max P } \\
\text { GR + Max P } \\
\text { Cold to T1 } \\
\text { Sus. + E1 } \\
\text { Sus. + E2 } \\
\text { Sus. + E3 }\end{array}$ & $\begin{array}{l}6 \\
0 \\
6 \\
6 \\
6\end{array}$ & $\begin{array}{l}0 \\
0 \\
1 \\
0 \\
0\end{array}$ & 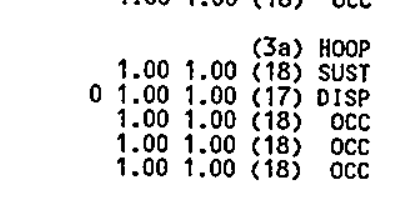 & $\begin{array}{l}896 \\
446 \\
456 \\
446 \\
446\end{array}$ & $\begin{array}{l}22<11 \\
16700 \\
16700 \\
25050 \\
22211 \\
22211 \\
22211\end{array}$ & $\begin{array}{l}\text { Maximum X } \\
\text { Maximum } \\
\text { Maximum } Z \\
\text { Maxime } \\
\text { Max. total }\end{array}$ & $\begin{array}{l}0.012 \\
0.387 \\
0.013 \\
0.387\end{array}$ & $\begin{array}{l:l}\text { Point }: & \text { A34 } \\
\text { Point } & \text { A14 } \\
\text { Point } & \text { AO7 } \\
\text { Point } & \text { A14 }\end{array}$ & $\begin{array}{l}\text { Load comb.: GR } \\
\text { Load comb.: TOTAL } \\
\text { Load Comb.: GR } \\
\text { Load comb.: TOTAL }\end{array}$ & \\
\hline A38 & $\begin{array}{l}\text { Max } P \\
\text { GR }+ \text { Max } P \\
\text { Cold to T1 } \\
\text { Sus. + E1 } \\
\text { Sus. + E2 } \\
\text { Sus. + E3 }\end{array}$ & $\begin{array}{r}42 \\
0 \\
42 \\
42 \\
42\end{array}$ & $\begin{array}{l}0 \\
0 \\
9 \\
0 \\
0\end{array}$ & 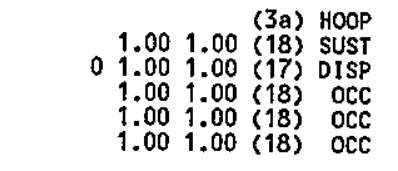 & $\begin{array}{l}896 \\
719 \\
790 \\
719 \\
719\end{array}$ & $\begin{array}{l}16700 \\
16700 \\
25050 \\
22211 \\
22211 \\
22211\end{array}$ & $\begin{array}{l}\text { Maximum } X \\
\text { Maximum } Y \\
\text { Maximum } Z \\
\text { Max. total }\end{array}$ & $\begin{array}{r}264 \\
-136 \\
511 \\
576\end{array}$ & $\begin{array}{l}\text { Point : } A 00 \\
\text { Point } \\
\text { Point } \\
\text { Point } \\
\text { Point }\end{array}$ & $\begin{array}{l}\text { Load Comb.: TOTAL } \\
\text { Load Comb.: GR } \\
\text { Lad comb.: TOTAL } \\
\text { Load Comb.: TOTAL }\end{array}$ & \\
\hline A39 & $\begin{array}{l}\text { Max } P \\
G R+\operatorname{Max} P \\
\text { Cold to } P 1 \\
\text { Sus. + E1 } \\
\text { Sus. + E2 } \\
\text { Sus. }+ \text { E3 }\end{array}$ & $\begin{array}{l}0 \\
0 \\
0 \\
0 \\
0\end{array}$ & $\begin{array}{l}0 \\
0 \\
0 \\
0 \\
0\end{array}$ & 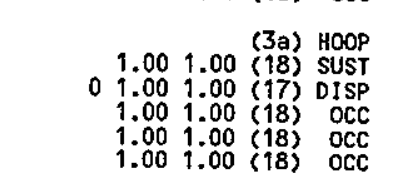 & $\begin{array}{l}896 \\
402 \\
00 \\
402 \\
402 \\
402\end{array}$ & $\begin{array}{l}16700 \\
16700 \\
25050 \\
22211 \\
22211 \\
22211\end{array}$ & $\begin{array}{l}\text { Maximum restraint moment } \\
\text { Maximum } X \vdots \\
\text { Maximmm } Y \\
\text { Maximum } Z \\
\text { Max. totat }\end{array}$ & $\begin{array}{l}s(f t-l b) \\
-36 \\
1011 \\
1012\end{array}$ & $\begin{array}{l}\text { Point : } A 00 \\
\text { Point }: A 00 \\
\text { Point } \\
\text { Point }: A 00 \\
\text { PoO }\end{array}$ & $\begin{array}{l}\text { Load Comb.: GR } \\
\text { Load Comb.: TOTAL } \\
\text { Load Comb.: GR } \\
\text { Load comb.: TOTAL }\end{array}$ & \\
\hline$* * \star$ Seg & gment $A$ end & $\star \star \star$ & & 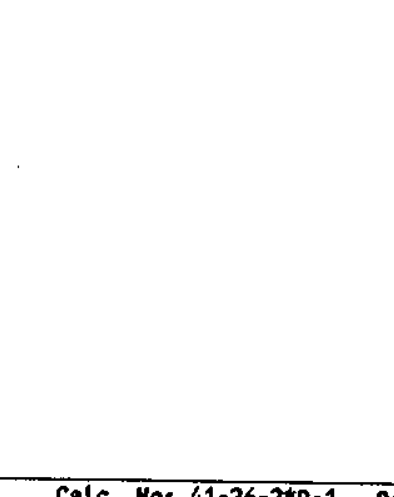 & & - & $\cdots$ & - & . & & \\
\hline
\end{tabular}




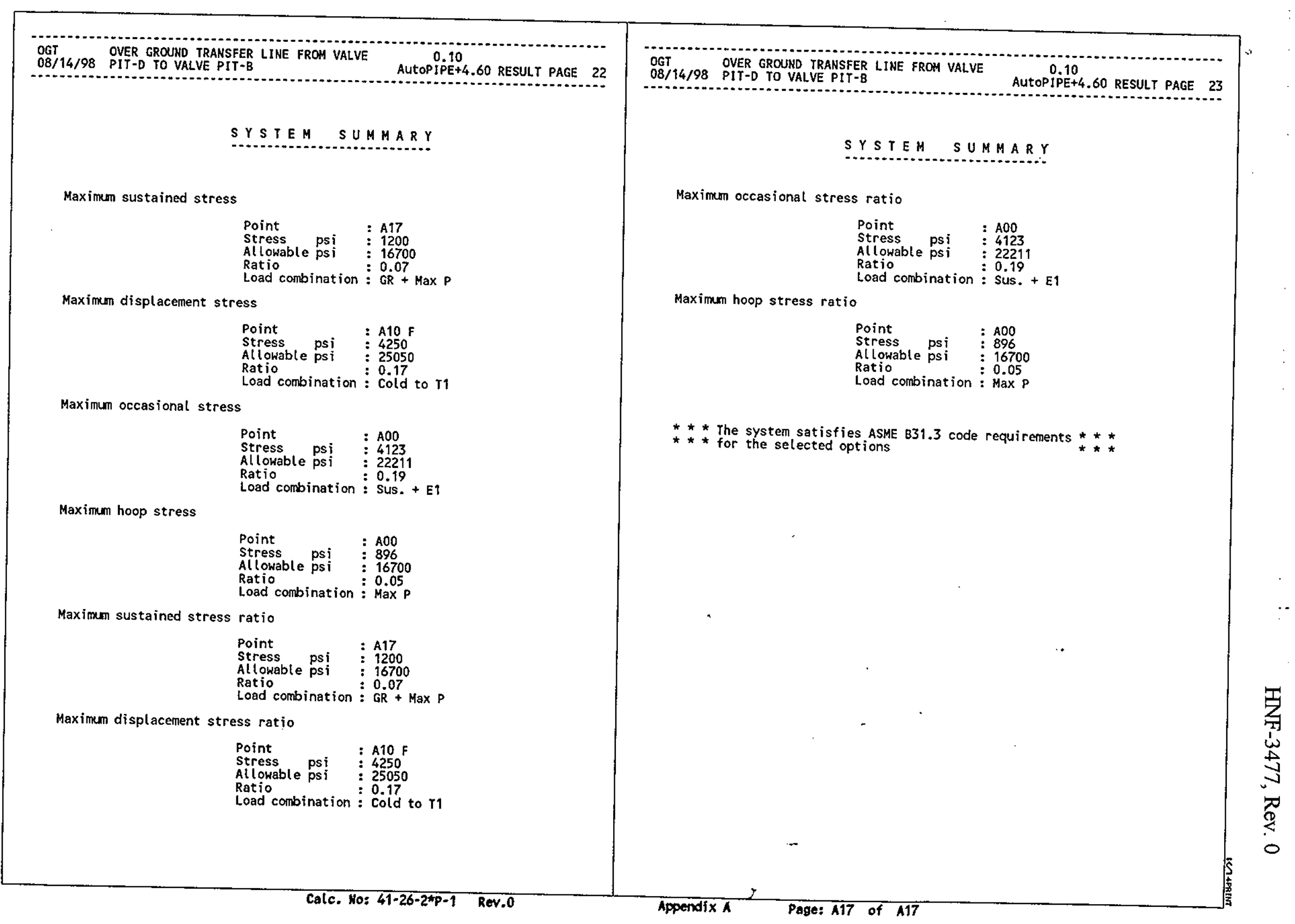


HNF-3477, Rev. 0

\section{FLUOR DANIEL NORTHWEST}

\section{CALCULATION IDENTIFICATION AND INDEX}

Page $i$ of $i$

$8 / 25 / 98$

This sheet shows the status and description of the attached Design Analysis sheets.

Discipline Structural WO/Job No. $41-26-2$

Project No. \& Name S-farm OGT line

Calculation No. $4 \mid-26-2 \times c-1$

Calculation Item Concrete Shielding stability \& \& PIPE SUPPORTS.

These calculations apply to:

Dwg. No. H-2-829565 sh 1

Rev. No. 0

Dwg. No.

Other (Study, CDR)

Rev. No.

Rev. No.

The status of these calculations is:

[1 Preliminary Calculations

[X] Final Calculations

[] Check Calculations (On Calculation Dated)

[] Void Calculation (Reason Voided)

Incorporated in Final Drawings?

This calculation verified by independent "check" calculations?

[X] Yes [] No

[] Yes [X] No

Original and Revised Calculation Approvals:

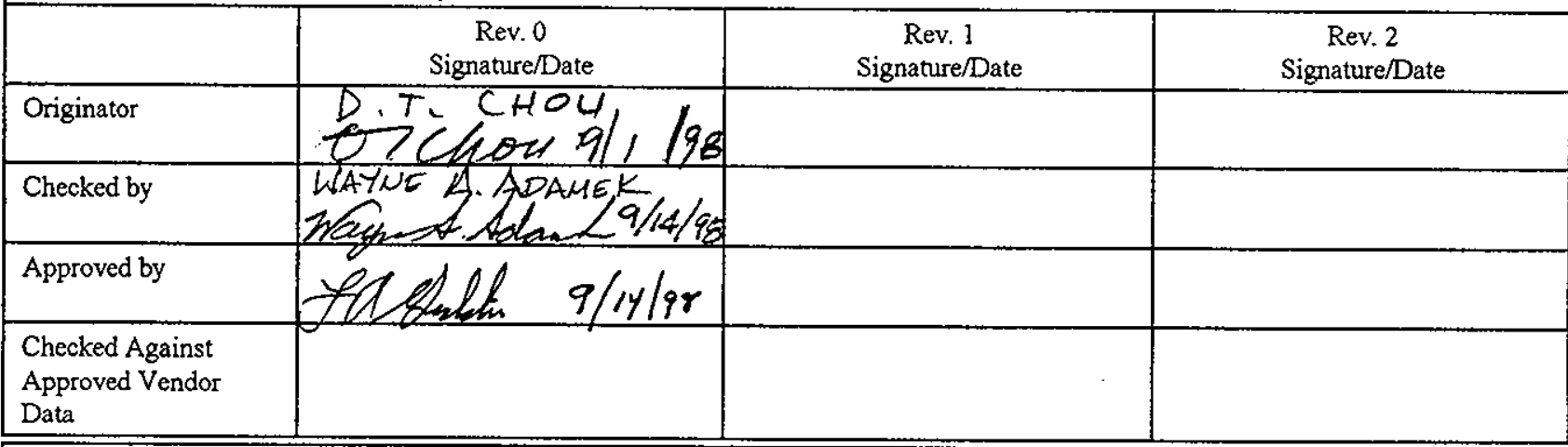

Design Analysis

Page No.

INDEX

\begin{tabular}{|c|l|}
\hline 1 & Objective, Criteria, Methods, References, Conclusion \\
\hline $2-5$ & Analysis CONC SHIELDING STABILITY \\
\hline $6-11$ & PIPE SUPPORTS \\
\hline & \\
\hline & \\
\hline AI \&AZ & PIPING RESTRAINT REACTIONS \\
\hline
\end{tabular}


HNF-3477, Rev. 0

\section{FLUOR DANIEL NORTAWEST}

DESIGN ANALYSIS

Client LMHC

Subject Concrete shielding stability

Location 200 Area
Calc. No. $41-26-2 * c-1$

Revision 0

Page No.l of 11

WO/Job No. $41-26-2$

Date $8 / 25 / 98$. By D T Chou

Checked $9 / 4 / 98$ By I/A

Revised By

\section{Objective}

1. Check stabililty of the concrete shielding for the seismic, wind, and vehicle impact loads.

2. DESIGN PIPE SUPPORTS

Criteria

The conc shielding is a Safety Class structure. It is for a temporary installation. The natural phenomena hazards design requirements for it is Performance Category 3 design loads.

Methods Hand Calculation

References 1. NOT USED

2. Dwgs $\mathrm{H}-14-100414$ sh $1, \& 2 \mathrm{rev} 0$ for the existing conc shielding structures

3. Dwg H-2-829565 shl, rev 0 for the OGT line

4. HNF-SD-BIO-001 rev 0, 5.3.2.23, natural phenomena

5. DWG $H-2-829564$ SHTS 1 \& .FOR PIPE SUPPORTS.

Design input

6. CALC. $41-26-Z * P-1$, REV. 0 .

The conc shielding blocks have been precasted, and will be lifted into place. The structural design of the blocks are not in the scope of this calc.

\section{Conclusion}

1. Stability of the conc shielding blocks for the specified loads are adequate.

2. DESIGNED THE PIPE SUPPORTS AS SHOWN ON THE DWGS, REO $O$. 
-FA N-347\%, REV. 0

FLUOR DANIEL. NORTHWEST, INC.

DESIGN ANALYSIS
Calc. No. $41-26-2 * c-1$

Revision

Page No. 2 of

Client LMHC

Wo/Job No. $41-26-2$

Subject CONC SHIELONG STABILITY Date $8 / 25 / 98$ BY OTC

Location 200

Revised

By

LOADINGS.

DI SECTIONAIH-14-1004/4 SH I.

$$
\begin{aligned}
D L & =\left[\left(1.0^{\prime} \times 4.0^{\prime}\right)(2 E A)+1.0^{\prime} \times 2.42^{\prime}\right]\left(1.5^{\mathrm{kCF})}\right. \\
& =156^{\mathrm{K} L F}
\end{aligned}
$$

LL ROOF/ELEUATED.

USE $L L=20 P S F$

WIND BY INSPECTION, IT DOES MOT GOVERN C SEISMIC GOVERNS). (ASSUME sO PSF PRESSURE, $P=30$ PSF $+1 \times 4^{\prime}=120^{\text {PL. }) . ~}$

$5=12+1 \mathrm{C}$ USE EQUIVALENT STATIC LOAD FOR DYNAMIC ANALYSIS

REF 4 BIO EVALUATION BS IS EARTHQUAKE: PEAK HORDE GROUND ACC $=.19 \mathrm{~g}, 10^{-1} / 4 R$ TREF 1. PRO -97. TABLE 6, SITE SPECIFL ? SPECTRA, FR E P.C:3,200 PEAKGGOUND ACC $26 \mathrm{~g}$ TO THE SHILOH IS A SIPLE TRLGLO STRUCTURE ON. THE GROUND SURFACE

BD-6002-142 (12/96)

D-2-3 
HNF-3477; Rev: 0

FLUOR DANIEL NORTHWEST, INC.

DESIGN ANALYSIS
Talc. No. $41-26-2 * c-1$

Revision $\frac{0}{3}$

Client LMHC wO/Job No. $4 /-26-2$

\begin{tabular}{lll}
\hline Subject CONC SHIELDING STABILITY & Date $8 / 25 / 98 \mathrm{By}$ \\
\hline Location 200 & Checked $9 / 14 / 98$ & $\mathrm{By}$ \\
\hline
\end{tabular}

SEISMIC (CONTD)

USE COSMIC RESPONSE $=.19 \mathrm{~g} \times 1.5=0.29 \mathrm{~g}$.

(TO COVER MULTIPLE MODELS) 4 .

VERT SEISML RESPONSE $=\frac{2}{3} \times Q_{h}=0.19 \mathrm{~g}$.

CHECK SLIDING.

THE SHIELDING SIT ON THE GROUND .

FRLITON RESISTANCE GRAVEL FOUNDATION

REF, FOUNOATON ANALYSIS AND DESIGN" JÖSEPHBOWLES

$\phi=40^{\circ},(P G, 30)$. ANGLE OF INTERNAL FRICTION.

$f=.67 \tan \phi$. (P G.379). COFF OF FRICTION

$=0.56$, USE 0.5 .

CONC. BASE \$ SOIL

SEISMIC LATERAL FORCE $=0.29 \pi$

FRICTION RESISTANCE $=0.50$

SEISM VERT, FORCE $=0.19 \mathrm{~W}$.

SEISMIC FORGE DIRECTIONAL COMBINATION

LO TRANSVERSE +0.4 VERT.

$$
F_{S}=\frac{0.5(1-0.4 \times 0.19) W}{0.290}=1.59>1.50 \mathrm{~K}
$$

BD-6002-142 (12/96)

D-2-4 
$\mathrm{HAN}=3477$, Rev: 0

3

FLUOR DANIEL NORTHWEST, INC.

DESIGN ANALYSIS
Call. No. $41-26-2 * c-1$

Revision $\frac{0}{4}$ of

Client LMHC

Wo/sob No. $4 /-26-2$

Subject CONC SHIELDING STABILIYY Date $8 / 25 / 98$ By DTC

Location 200

Revised

By

CHECK OVERTURNING

$$
\begin{aligned}
& E_{0} E_{H 1} \quad E_{H 1}=4.5 \times 1.0 \times .15 \times .29 \mathrm{~g}=220^{K} \\
& E_{H_{2}}=3.0 \times 10 \times 2^{E A+} \times .15 \times .29=.26^{k} \\
& E_{V}=19 \times 1.56^{k}=.30^{k} \\
& \text { A. } \frac{2.3|z B|}{2} \\
& \omega=1.56 \text {. } \\
& M=\left(20^{k} \times 3,5^{1}+26^{k} \times 1.5^{\prime}\right)+\left(.30^{k} \times 2.31 \times 0.4\right) \\
& =1137.1 k \\
& \text { DIRECTIONAL } \\
& \text { COMBINATION } \\
& M_{R}=1.56-x_{2} 3^{-1}=3.59 \\
& F_{-S}=M_{R / H O}=2.6>h \text { ok }
\end{aligned}
$$

CHECK SOIL BEARING

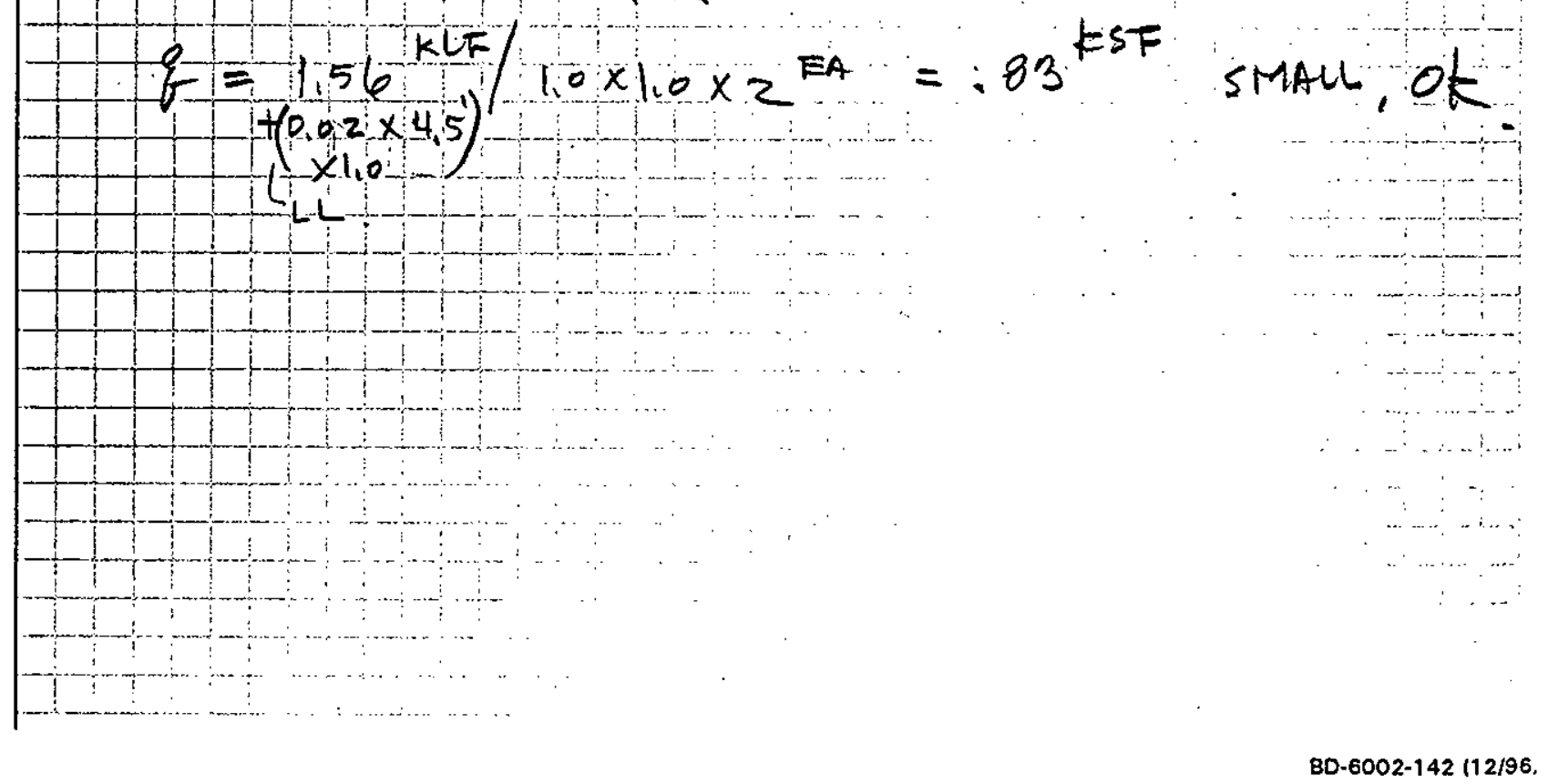

D-2-5 
HNF-3477, Rev. 0

4 FLUOR DANIEL. NORTHWEST, INC.

$$
\begin{aligned}
& \text { Call. No. } \frac{41-26-2 * c-1}{0} \\
& \text { Revision } \frac{0}{5 \text { of }}
\end{aligned}
$$

Client $H$ MC

DESIGN ANALYSIS

Subject $C$ Wo/Job No. $41-26-2$

Date $8 / 25198$ By DTC

Location. Zoo

Revised

By

CHECK FOR THE VEHICLE IMPACT LOAD.

REF UBC 97. TABLE 16-B. AS BARRIER.

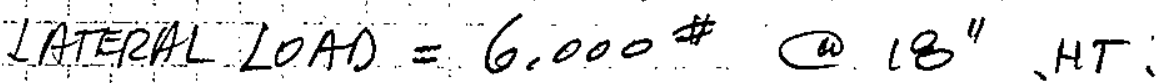

FRICTION RESISTANCE $=0.5 \times 1.56^{\mathrm{kWF}}=0.78^{\mathrm{KLF}}$.

LENGTH OF THE SHIELD REQUIRED TO RESIST. THE IMPACT.

$$
L=6.0^{k} / 78=7.7^{1} \times 1.5^{\text {FF I }}=11.6^{1}
$$

THE CONC SHILLINGS ARE LIOCERD TOGETHER BY THE JOINT BLOCKS, THE EFACCTIVE LENGTH TO RESIST THE IMPACT WILL BE MORE THAN THE RECD. (SLIDE GOVERNS $\quad O K$

BD-6002-142 (12/96)

D-2-6 
KAISER ENGINEERS

HANFORD

Client LMHC

Subject PIPE SMPPOKT
DESIGN ANALYSIS

Wo/Job No. 41-26-2 Date \& $125 / 95$ By Dow D. Wherienger Revised $8 / 26 / 98$ By

$\$ 5500$

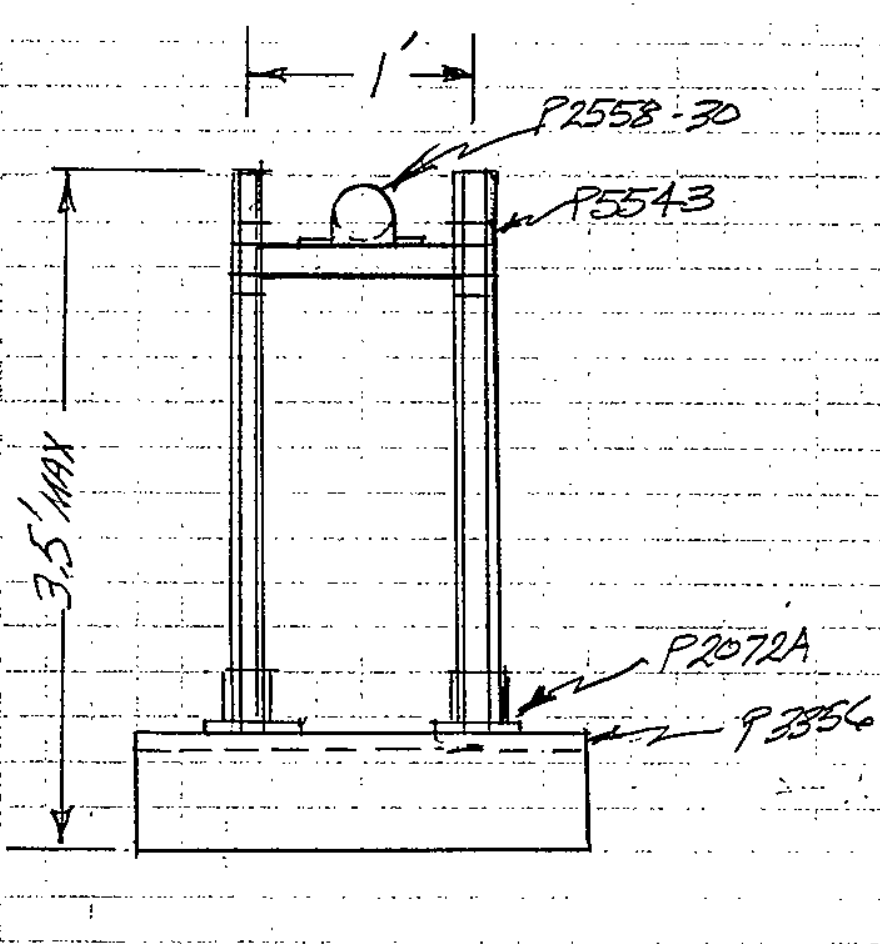

WEIGHT:

BLOEK: $6^{\prime \prime} \times 24^{\prime \prime} \times 8^{\prime \prime} / 1728 \mathrm{IN}^{3} / \mathrm{FT}=0.667 \mathrm{FT}$ $0.667 \mathrm{FT}^{3} \times 15016 / \mathrm{FT}^{3}=10046$

P5500 VNISTRIT $6 F T+F T=7 F T$ wT/FT=21416/4 $7 F T \times 2.47 \angle 6=17,316$

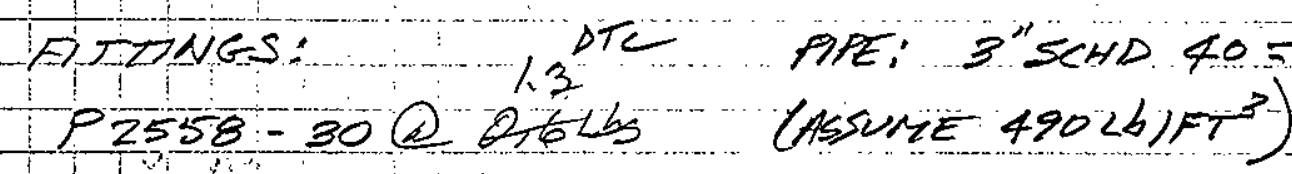
P55.23 Q 0.97165 P2072A@3.73̈Ls NEGLECT WEIGHT OF FASTEXERS NEOLECT HETGHT OF CHANNEL INSERT, VOID AREA $\therefore\left(\frac{3,06811)^{2} \pi}{4}=739 N^{2}\right.$ $\omega t=\frac{(62,4)}{F T^{2}}\left(0,051 F T^{2}\right) b^{2}$ $3,18 \mathrm{~b} / \mathrm{FT}$ 
HNF-3477, Rev. 0

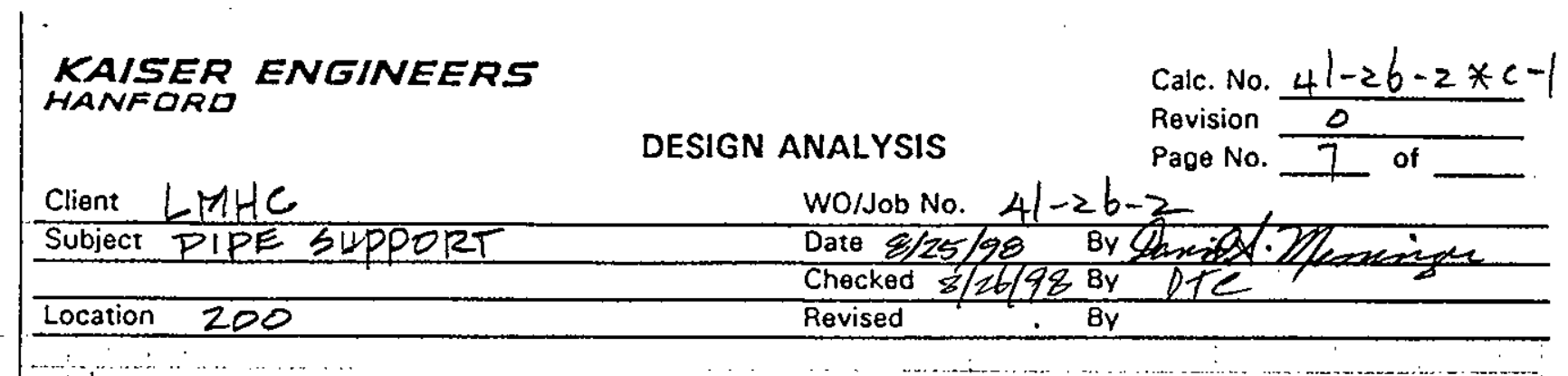

CENTER OF GRAYTY:

ASSHME \& PIPE AT 42 " ABOVE GRADE.

$108,2 \mathrm{Lb}$

PNE; $\left[(7,38+3,18) 10^{\prime}+0.64672^{\prime \prime}=45444 N-\angle 6\right.$

SLPPORT BOR:

$$
\begin{aligned}
& {[(2,4716)+2(0.97 \angle 55)]\left[42^{\prime \prime}-\frac{\left(3.5+1.625^{\prime \prime}\right)}{2}\right]} \\
& =(4,41 \mathrm{Lb})(39.44 \mathrm{~N})= \\
&
\end{aligned}
$$

VENCAL $\angle E E S, \quad Z(2,47 \angle b) / F F)(24 \mathrm{~N})$

$$
=(148216)(24 N)=355,68, N-16
$$

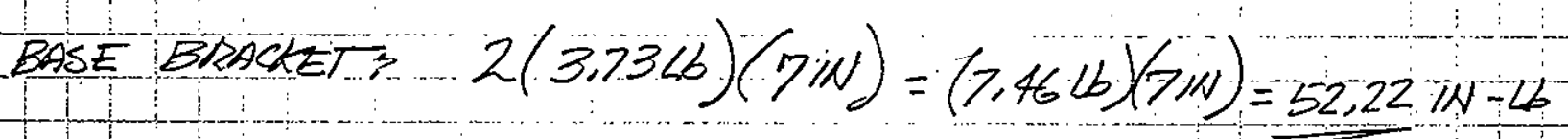
BASE BLOCK,,$(10 \Delta L b)(3 N) \quad 300 N-\angle b$

TOTAL WEGH PER SUPPORT:

$$
\begin{aligned}
& \text { wt }=(108.2+4.4+1482+7.467100) 26=234966 \\
& \text { wt noraut }=(45444+173.92+355.68+52,22+300) \mathrm{N}-\angle \mathrm{b}=5426.2 \mathrm{~L} / \mathrm{N}
\end{aligned}
$$

$$
y=(5426,22 N-26 / 234,9 \angle 6)=23,1 N \text { ABOVE SolL }
$$

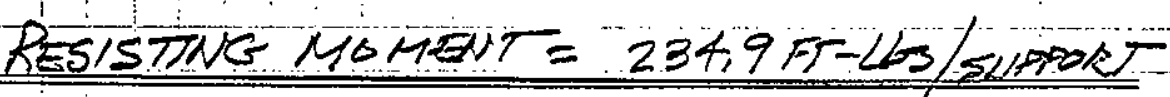

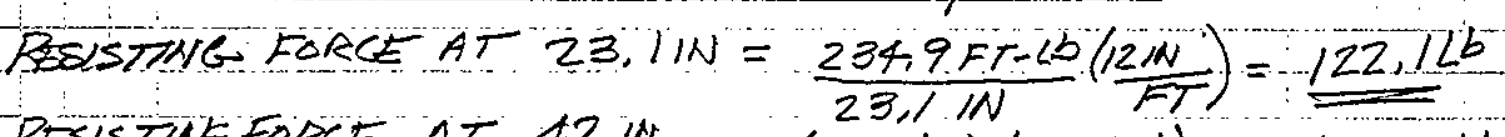

RESISTINEFOLCE AT $42 N=(23,1 / 42)(122,116)=67,16.16$

\& o.po. ${ }^{2} 689-996 \quad 12794$

$D-2-8$ 
HNF-3477; Rev. 0

KAISER ENGINEERS HANFORD

DESIGN ANALYSIS

Client LWHC

Subject PIPE SILPPORT

Location 20

WO/Job No. $4 \mid-2 b-2$

Calc. No. $\frac{41-26-2 *<-1}{0}$

Page No.

8 of

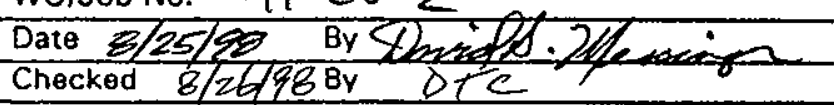
Revised By

BESISTANCE TO SLIANG:

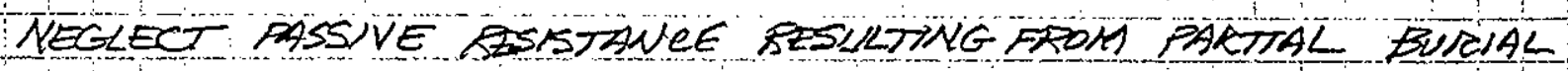

(FROH REF \% IG 37\%) ASSUAE $f($ RRITNON BCTOR) $=0.55$

SLIDING RESISTANCE:

$$
\left.P_{s}=\bar{W} f=(234,16)(0,55)=129,2\right)
$$

\section{SUMUARY:}

1) PESISTOWEE TO OVERTHRVING FOR FORCE INDUCED AT 42 IN ABOVE GEADE (SUCA AS KND OR TNERYAL) 6716262

2) RESISTACE TO OVERTIRXING FROM LOADS AT CO YUCHAS SESAIC $=122,126 @ 2 / 3=8 / 32 \mathrm{~L}=$

3) RESISTANCE TO SKIDNNC $=129,2 \mathrm{Zb}$ 
HNF-3477, Rev. 0

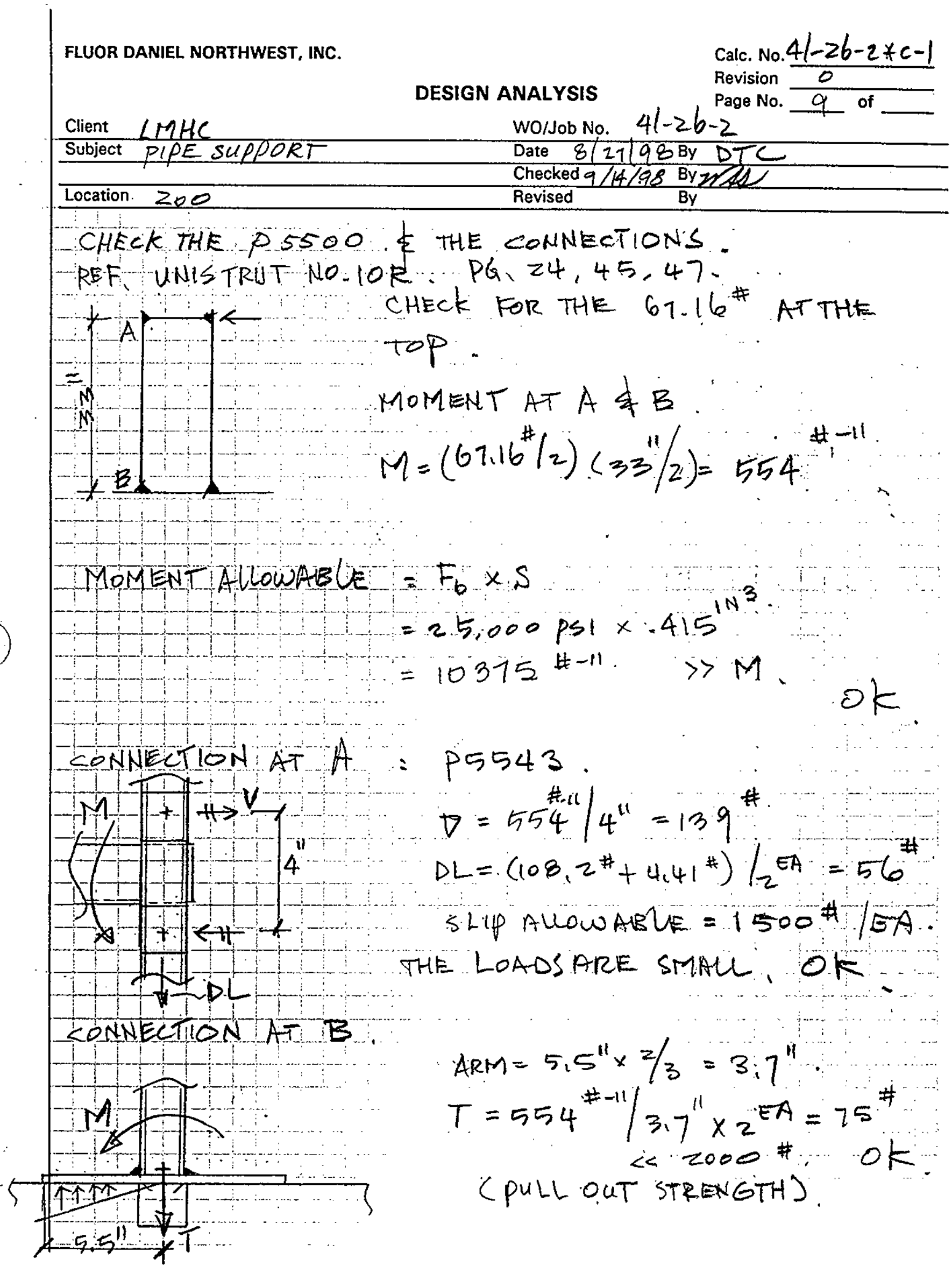

BD-6002-142 (12/96)

D-2-10 
KAISER ENGINEERS
HANFORD

DESIGN ANALYSIS

HNNF-3477, Rev. 0

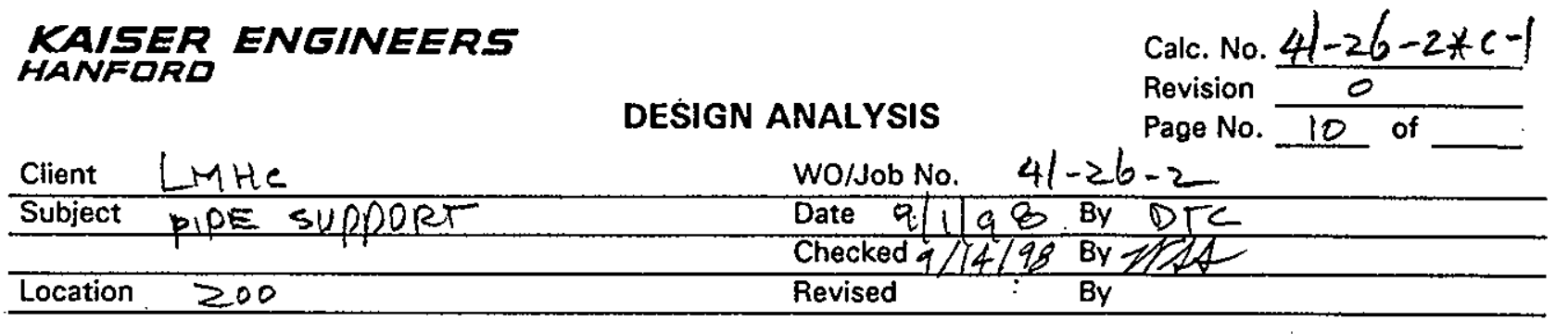

SEE THE REF. 6, THE PIPING CALC. APDENDIX A $A 11$ \& $A 1 Z$, (ATTACHED AS AL \&AZ)

THE GOVERNING RESTRAINT: REACTIONS AT THE PIPE SUPPORTS. (EXCLUDE THE fOO ANCHOR AT THE PIT, E A.15 (support).

$$
x_{\text {max }}=51^{\angle B 3}<67.16^{\angle B 1}
$$

ok

(TRANSVERSE

$Y_{\text {max }}=135^{\text {LB 3 }}$ SMALL, BY ENGINEERING JUDGE TAN (VERT: LOADS).

$Z_{\text {max }}=53^{\text {LBS }}$ SMAlL, BY ENG. JUDGEMENT (LONGITUDINAL PIPE DIR.). OK

NOTE: HOO ANCHOR AT THE PIT IS CHECKED BY OTHERS.

THE $Y$-STOP SUPPORT AT ADS, WI $=85 \mathrm{LBS}$ PER THE PIPING ENGR / ORIGINATOR OF THE CALL THE X LOAD IS FRICTION, TO BE IGNORED FOR THE PIPE SUPPORT CHECK.

54-4300-037 KEH-0037.00 (06/92)

D-2-11 
HNF=3477, Rent. 0

FLUOR DANIEL NORTHWEST, INC.

DESIGN ANALYSIS

Client LMHC

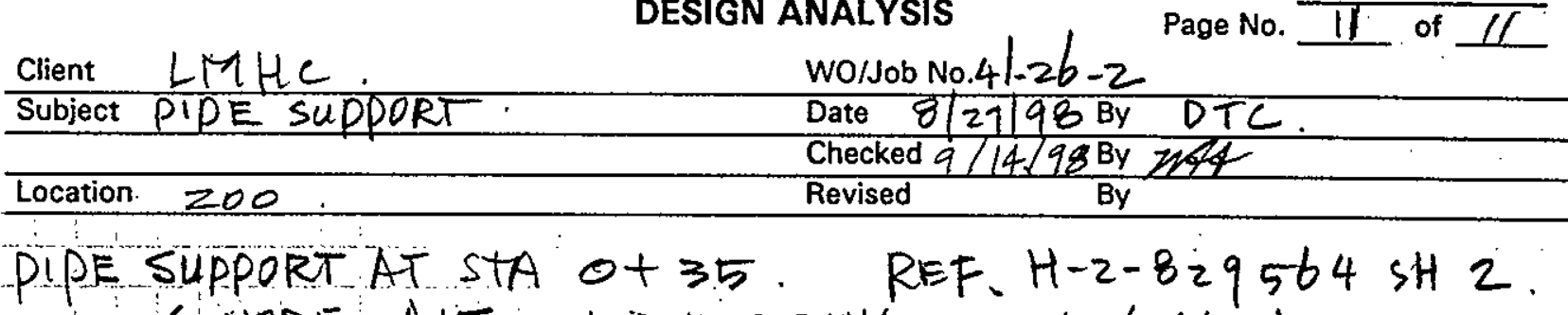

(NODE AIS IN THE PIPING MODEL/LALC).

THE LATERAL RESTRAINT OF THIS SUPPORT IS BY THE

CONC SHIELDING BLock.

CHECK FOR A PIPE REACTION (HORIZ). OF $300^{*}$ AT THIS SUPPORT ASSUME IT IS DISTRIBUTED TO $5^{\prime}$ (CONSERV.) $P=300 / 5=60$ PL

REF PS 3 \& 4 THE CONC SHIELDING BLOCKS HAVE MARGINS TO TAKE THIS ADOITONAL PIPE LOADS.

THE PIPE SUPPORT IS ADEQUATE

* the actual load der the Refl. All OF A17. (SEEAPP.AT), $X=z I$ LBS $\quad$ THE USED LOAD
Calc. No. $4(-26-2 * c-1$

Revision 0

Page No. If of $1 /$ 


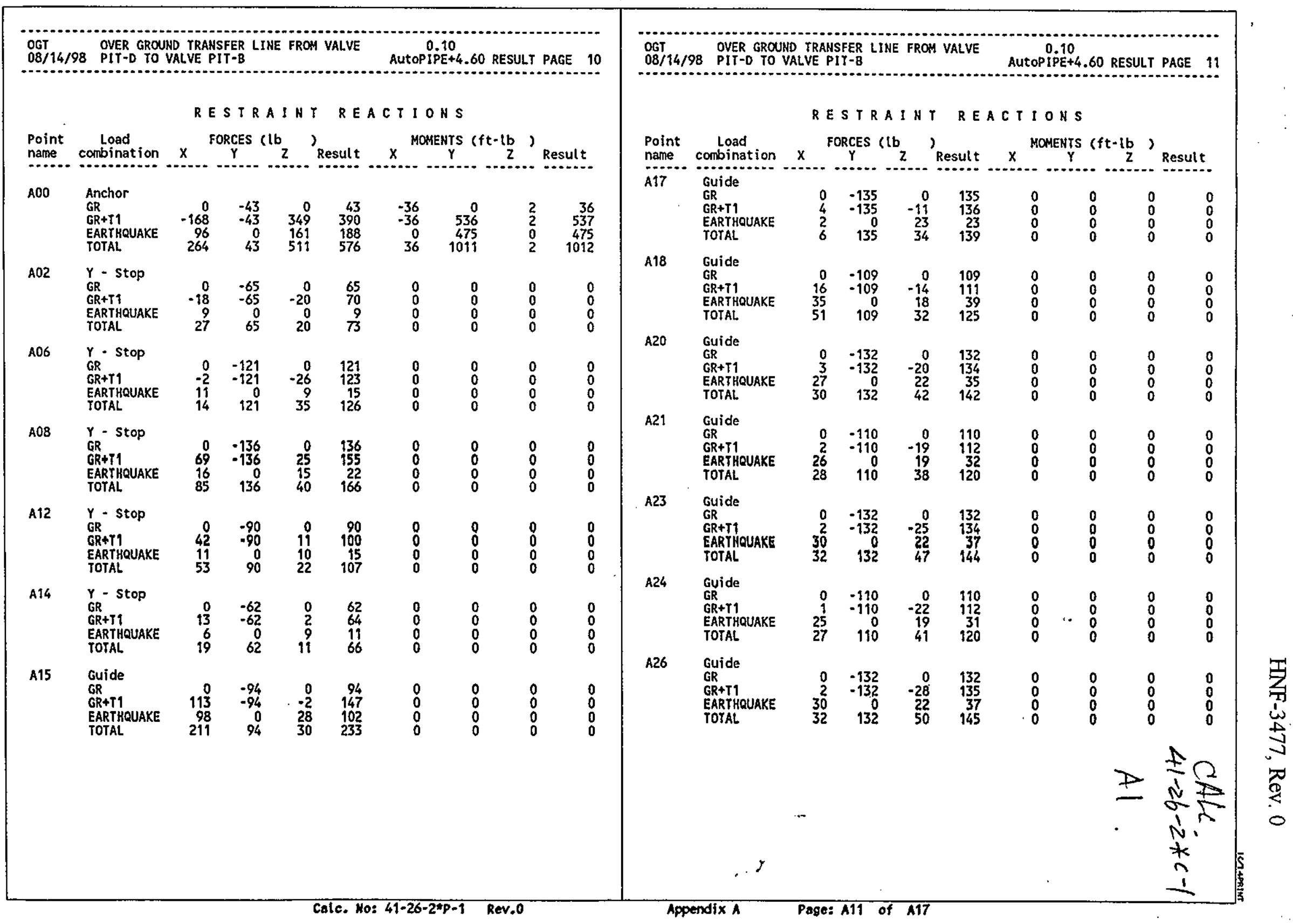




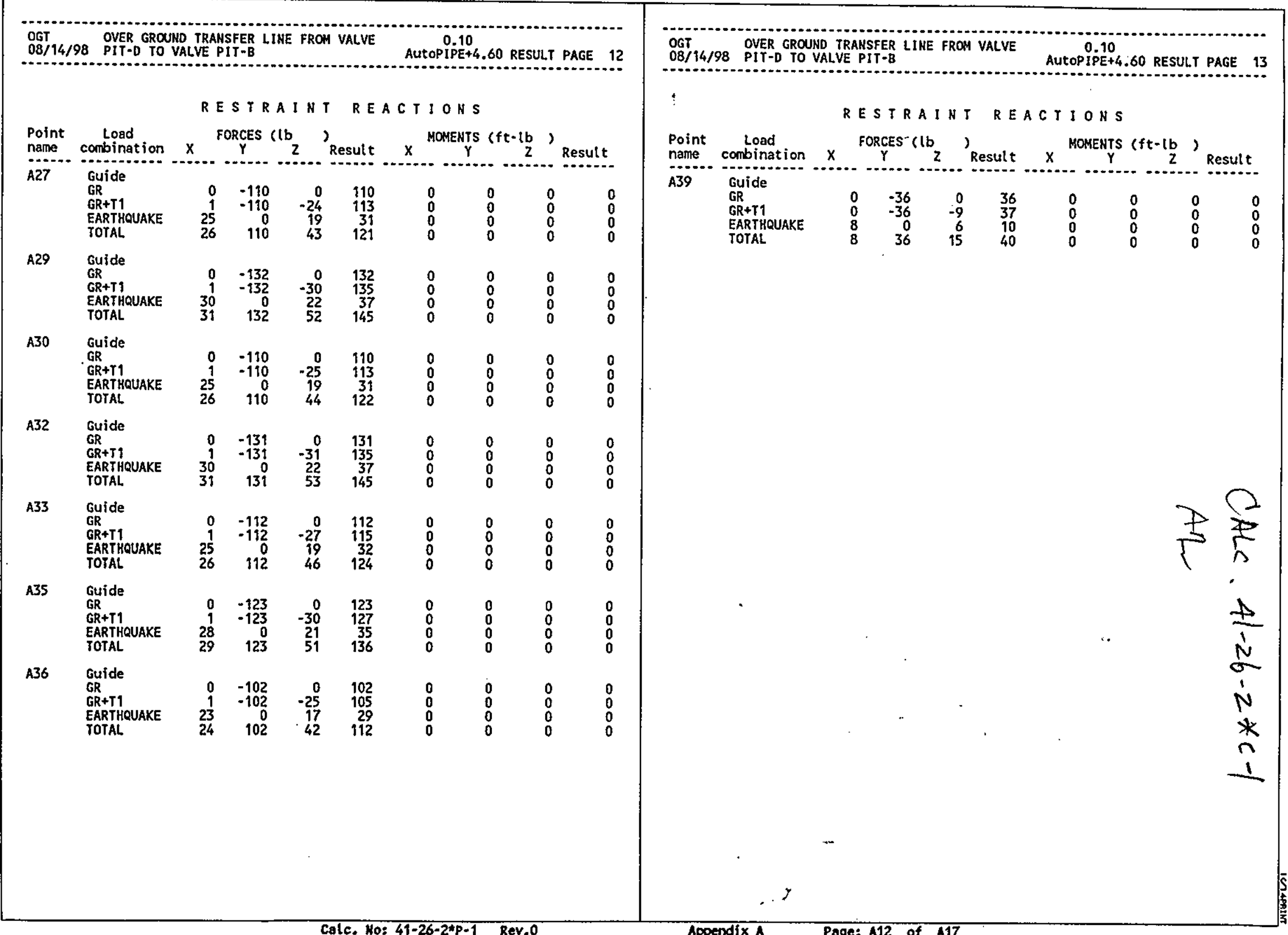


HNF-3477, Rev. 0

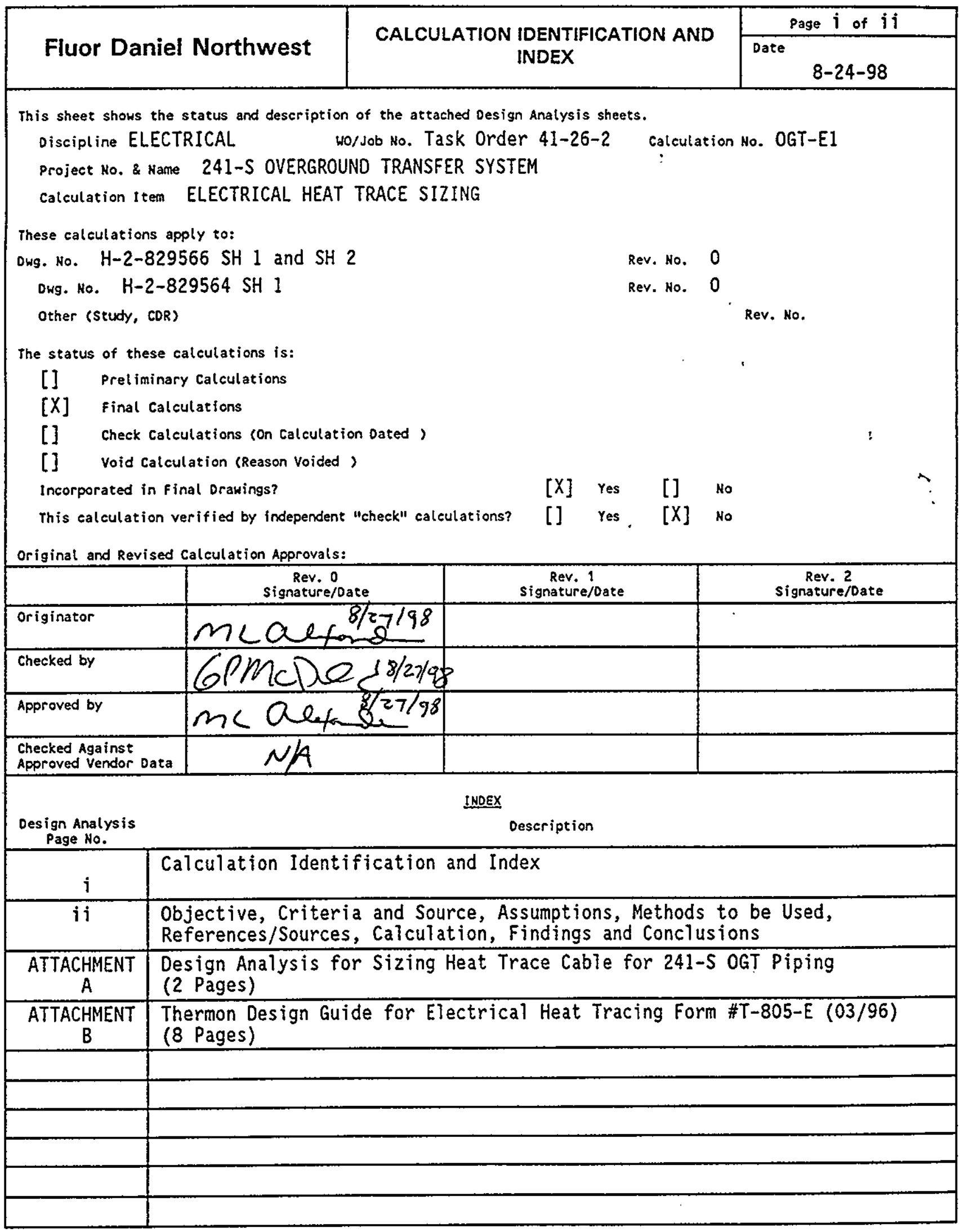

A-6002-143 (01/97) GEF410 


\section{Fluor Daniel Northwest}

\section{DESIGN ANALYSIS}

Client NHC

subject 241-S OGT PIPELINE HEAT TRACING

Location 241-AZ-702
Catc. No. OGT-El

Revision 0

Page No. $i i$ of $i i$

wo/sob No. TASK ORDER 41-26-2

Date 8-24-98

checked $8 \cdot 27.98$

Revised
8Y M. L. ALEXANDER mod

By Gom

By

\section{OBJECTIVE:}

To provide design analyses for sizing the electric heat trace cable for the 241-5 Over Ground Transfer (OGT) Pipeline.

II. DESIGN INPUTS:

Criteria and Source:

Task Order \#41-26-2 to design OGT pipeline between valve pit 241-S-B and valve pit 241-S-D.

Given or Known Data:

Temperature Range $-10^{\circ} \mathrm{F}$ to $113^{\circ} \mathrm{F}$ (maintained); $3^{\prime \prime}$ Encasement Pipe; $1-1 / 2^{\prime \prime}$

Cellular Glass Insulation; Two 120 Vac heat trace circuits required with length of each circuit less than 120 feet; Thermon brand heat tracing to be used.

Safety Classification - General Service; No hazardous atmosphere.

Assumptions: NONE

Methods to be Used:

Thermon Design Guide for Electric Heat Tracing

References/Sources:

Thermon Complex Piping Design Guide for Electric Heat Tracing Form \#T-805-E $(03 / 96)$. See Attachment B.

Calculation: See Attachment A.

Findings and Conclusions:

The electric heat tracing for the 241-S OGT pipeline is sized to maintain the temperature on the $3^{\prime \prime}$ encasement pipe at $113^{\circ} \mathrm{F}$ down to an ambient temperature of $-10^{\circ} \mathrm{F}$. Thermon TSX $12-1$ self-regulating heating cable meets the requirements for heat tracing the OGT pipeline. 
HNF-3477, Rev. 0

ATTACHMENT A

!

2

D-3-3 


\section{Fluor Daniel Northwest}

DESIGN ANALYSIS

client NHC

subject 241-S OGT PIPELINE HEAT TRACING

Location 241-AZ-702
Calc. No. OGT-EI

Revision 0

Page No. 1 of 2

wo/sob No. TASK ORDER 41-26-2

Date 8-24-98

By M. L. ALEXANDER mes

checked 3.27 .98 By 6 Rin

Revised

\section{CALCULATION}

This calculation follows the guidelines outlined in the Thermon Complex Piping Design Guide for Electric Heat Tracing (See Appendix B)

Design Parameters:

Pipe Size $=3^{\prime \prime}$

$\mathrm{Ta}=$ Minimum Ambient Temperature $=-10^{\circ} \mathrm{F}$

$\mathrm{Tp}=$ Pipe Maintain Temperature $=113^{\circ} \mathrm{F}$

Voltage $=120 \mathrm{VaC}$

Insulation $=1-1 / 2 "$ Cellular Glass

Location $=$ Outdoors

Step 1) Find Heat Loss:

a. Calculate Temperature Differential

$$
\Delta T=T p-T a=113-(-10)=123^{\circ} \mathrm{F}
$$

b. Determine Pipe Base Heat Loss (Qb)

$Q b=7.17 \mathrm{~W} / \mathrm{ft}$ from Chart 1 for $3^{\prime \prime}$ Pipe with $1-1 / 2^{\prime \prime}$ Insulation $0123^{\circ} \mathrm{F}$

Interpolation Required $Q b=5.7+(23 / 50)(8.9-5.7)=7.17$

c. Adjust Base Heat Loss for Insulation Type (ICf = Insulation Factor from Chart 2)

$Q \mathrm{Q}=Q b \times I c f=7.17 \times 1.60=11.47 \mathrm{~W} / \mathrm{ft}$

Step 2) Heating Cable Product Selection

a. Look at TSX which is good for $250^{\circ} \mathrm{F}$ maintenance temperature and $375^{\circ} \mathrm{F}$ exposure temperature.

b. Locate the Pipe Maintain Temperature on Graph 2 for TSX Cable and find the heating cable power level that will provide power $(\mathrm{w} / \mathrm{ft}$ ) equal to or greater than the calculated heat loss Qa $=11.47 \mathrm{w} / \mathrm{ft} @ 113^{\circ} \mathrm{F}$. From Graph 2 TSX $12-1$ heat cable is acceptable and is equal to or higher than the calculated heat loss and can therefore be applied in a straight run without spiralling.

c. Heat Trace Cable Length (See H-2-829564 Sh 1 and H-2-829566 Sh 1 \& Sh 2)

Circuit 1 Valve Pit 8 Coordinate $0+79$ to Coordinate $1+78=99$ feet +5 feet for flanges $=104$ feet.

Circuit 2 Valve Pit $D$ Coordinate $0+81$ to Coordinate $0+01=80$ feet +4 feet for $\mathrm{fl}$ anges $=84$ feet.

$80-6002-142(02 / 97)$ GEF409 
HNF-3477, Rev. 0

\section{Fluor Daniel Northwest}

DESIGN ANALYSIS

client NHC

subject 241-S OGT PIPELINE HEAT TRACING

Location 241-AZ-702
Calc. No. OGT-EI

Revision 0

Page No. 2 of 2

Ho/sob No. TASK ORDER 41-26-2

Date 8-24-98

Checked $8.27-98$ By $6 \mathrm{Am}$

Revised
BY M. L. ALEXANDERMLS

By

Step 3) Circuit Breaker Selection

Use Chart 6 for TSX Self-Regulating Heating Cables.

For TSX 12-1 maximum circuit length for a 15 ampere circuit breaker is 90 feet. For TSX 12-1 maximum circuit length for a 20 ampere circuit breaker is 120 feet.

Circuit 1 will require a 20 ampere circuit breaker.

Circuit 2 will require a 15 ampere circuit breaker.

Panelboard ' $B$ ' located at 241-S-271A will be used to provide power for the heat tracing circuits and has 20 ampere circuit breakers available to provide the power. Use 20 ampere circuit breakers for the OGT heat trace circuits.

Circuit 1 Power $=11.47 \mathrm{w} / \mathrm{ft} \times 104 \mathrm{ft}=1192.88$ watts

Circuit 2 Power $=11.47 \mathrm{w} / \mathrm{ft} \times 84$ feet $=963.48$ watts

For the 241-S OGT Pipeline heat tracing use Thermon TSX 12-1 self-regulating heating cable and associated components. 
ATTACHMENT B

!

D-3-6 


\section{Complex Piping \\ Design Guide for Electric Heat Tracing}

APPLICATION: This Design Guide for Electric Heat Tracing covers basic heat tracing design for in-piant complex piping using $\mathrm{SX}^{\mathrm{m}}$ self-regulating or HPT $\mathrm{T}^{\mathrm{*}}$ power-limiting heating cables. It is divided into four sections that include:

1. Piping System Layout and Design Parameters

2. Thermal Design

3. Heat Tracing Product Selection

4. Circuit Breaker Selection
For heat tracing designs that ...

- have start-up or heat-up requirements,

- include temperature sensitive fluids, or

- require other special considerations,

please consult your local representative or Thermon Service Center.

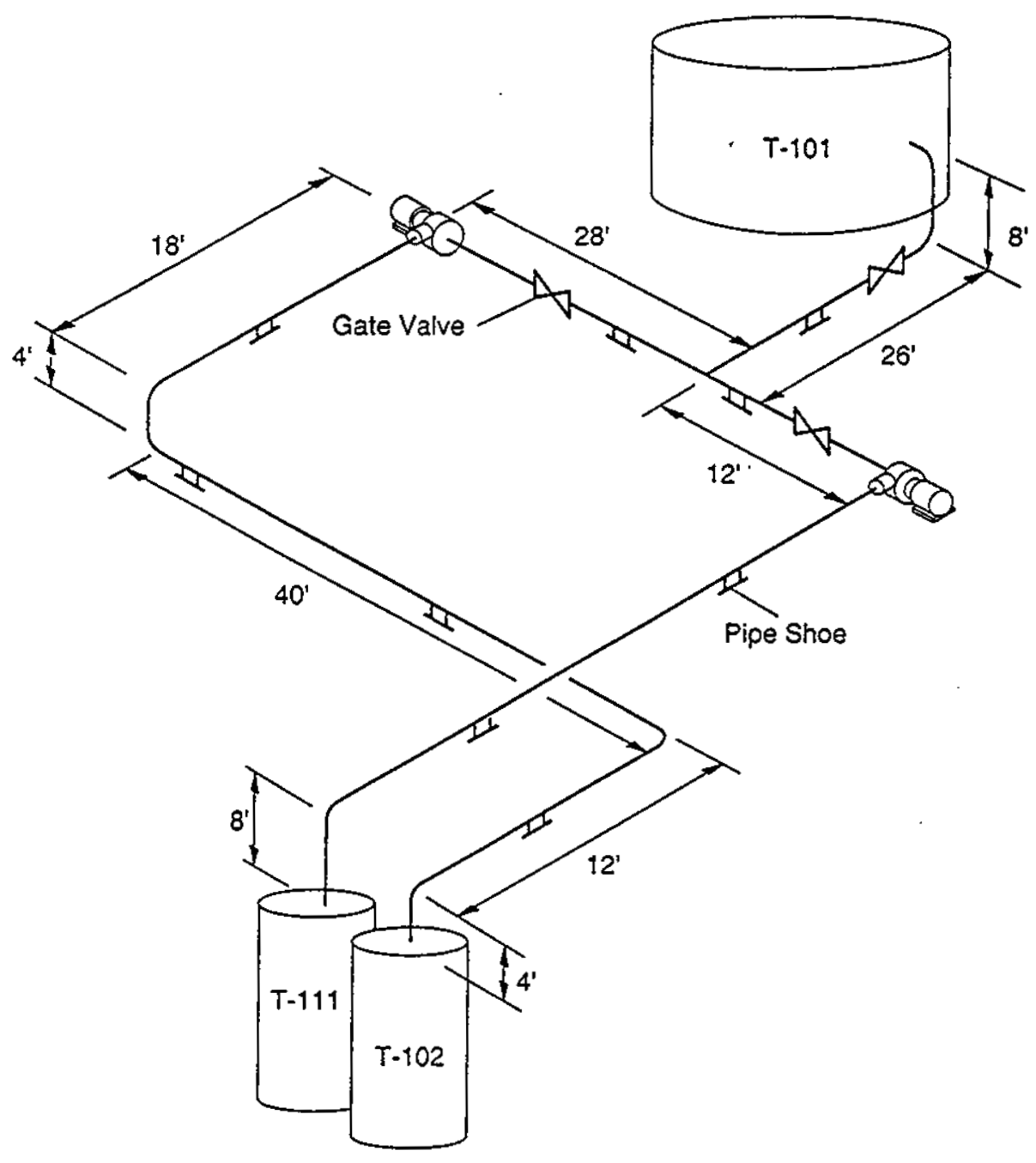




\section{HEAT TRACING SYSTEM LAYOUT}

Establish the piping and equipment to be heat traced from the line list, instrument drawings or isometric drawings. Based on the temperature control approach used, lay out the circuits in accordance with the guidelines in IEEE 515-1989, Section 6.7.

\section{DESIGN PARAMETERS}

Pipe Size $=$ inches (NPS)

Fluid = Water, Oil, Caustic, Etc.

$T_{2}=$ Minimum Ambient Temperature

$\mathrm{T}_{p}=$ Pipe Maintain Temperature

$\mathrm{T}_{\text {exp }}=$ Maximum Exposure Temperature

(Steam Cleanout or Purging?)

$T_{p \max }=$ Maximum Temperature Limit

(Plastic Pipe, Temperature Sensitive Process, Etc.)

Area Classification = Ordinary; Class 1, Division 2, Etc.

Voltage $=120 \mathrm{Vac}, 240 \mathrm{Vac}$, Etc.

Insulation $=$ Type, Thickness and Size

Location = Outdoors or Indoors

Pipe Start-Up Temperature = Minimum Pipe

Temperature When the Heater Will be Energized

(Unless otherwise specified, this is assumed to be $T_{a}$ )

\section{THERMAL, DESIGN}

The primary purpose of the heat tracing circuit is to replace the heat lost through the thermal insulation. As such, the first step associated with heat tracing circuit design is heat loss calculation (Refer to Chart 1 on page 4).
A. Calculate Temperature Differential $\Delta T=T_{0}-T_{2}\left({ }^{\circ} \mathrm{F}\right)$
B. Determine Pipe Base Heat Loss $\left(Q_{0}\right)$ $Q_{b}=\ldots$ w/ft from Chart 1 (Interpolate Intermediate Values)
C. Adjust Base Heat Loss $\left(Q_{2}\right)$ for Indoor Location and Insulation Type if Required $Q_{\mathrm{a}}=Q_{b} \times 0.9$ (if indoors) $\times I_{c t}$ $\left(l_{c t}\right.$ is Insulation Factor from Chart 2 on page 4)
D. Determine Valve and Pump Allowances (See Chart 3 on page 4)
E. Determine Accessory/Support Allowances (See Detail A on page 4)

These values are for temperature maintenance. For heat-up consult the factory.

\section{Example: Circuit Layout}

See sample drawing on cover of this brochure

1. Circuit 1 - Pipe Tee to Tank T-102
a. 3 " Pipe - Length is $106 \mathrm{ft}$.
b. 1 Flanged Valve, 5 Pipe Shoes - 9" Long, 1 Pump

2. Circuit 2 - Pipe Tee to Tank T-101

a. $3^{n}$ Pipe - Length is $34 \mathrm{ft}$.

b. 1 Flanged Valve, 1 Pipe Shoo - 9" Long

3. Circuit 3-Pipe Tee to Tank T-111

a. $3^{n}$ Pipe - Length is $50 \mathrm{ft}$.

b. 1 Flanged Valve, 3 Pipe Shoes $\cdot 9^{12}$ Long, 1 Pump

Fluid $=$ Fuel Oil

$\mathrm{T}_{\mathrm{a}}=-20^{\circ} \mathrm{F}$, Minimum Temperature

$T_{p}=120^{\circ} \mathrm{F}$, Maintain Temperature

$T_{\text {exp }}=366^{\circ} \mathrm{F}$ (150 psig Steam Purge)

Area Class $=$ Class 1, Division 2

Voltage $=120 \mathrm{Vac}$

Insulation = Mineral Wool $-2-1 / 2^{\prime \prime}$ Thick

Location $=$ Outdoórs

Pipe Start-Up Temperature $=0^{\circ} \mathrm{F}$

\section{Example: Heat Loss (From Chart 1)}

A. $\Delta \mathrm{T}=120^{\circ} \mathrm{F}-\left(-20^{\circ} \mathrm{F}\right)=140^{\circ} \mathrm{F}$

B. $Q_{b}=4.1 \mathrm{w} / \mathrm{ft}+[(40 / 50)(6.4-4.1)]=5.9 \mathrm{w} / \mathrm{ft}$

C. $\mathrm{Q}_{\mathrm{a}}=5.9 \times 1.0 \times 1.25=7.4 \mathrm{w} / \mathrm{ft}$

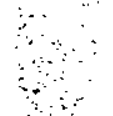

D. Flanged $3^{n}$ Valves: ( $3.5 \mathrm{ft}$ ) (\# of Valves) Flanged $3^{\prime \prime}$ Pumps: (7 ft.) (\# of Pumps)

E. Pipe Supports: $(2.5 \mathrm{ft}$.) (\# of Pipe Supports) 
HEAT TRACING PROOUCT SELECTION

Atter determuning the heat tosses of the insulated pipe at design maintenance temperature $\left(T_{j}\right)$ in the minimum mendattons in solecting a specific type of SX of HPT cable/system. For other apofications or heating cable se iles, consult appropriate design guides.

PSX, and rSX' Sels-Rogulating Heating Cable PST' Poures.Limiting Heating Cablo

Econo Trace' Conetant Watage Heating Cable TEK'HTEK'MMIO" Serles Resistance Heating Cables ThermTras" Skin EHtect Heating Systems

Hezt Tracing Solection Guldelines

\begin{tabular}{|c|c|c|c|c|}
\hline \multirow[b]{2}{*}{ Job Silo Canslderations } & \multicolumn{2}{|c|}{ Temperature Constoctsitons } & \multirow{2}{*}{ 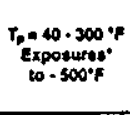 } & \multirow{2}{*}{ 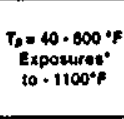 } \\
\hline & $T_{0}=40-150^{\circ} \mathrm{F}$ & 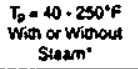 & & \\
\hline 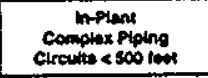 & PSX & TSX & MPT & Mio \\
\hline $\begin{array}{l}\text { Intarcomecting Ploing } \\
300<\text { C Crowiti < } 10000\end{array}$ & Et & FP & MPT & MюO \\
\hline 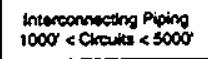 & TEK & TEK & HTEK & M10 \\
\hline $\begin{array}{l}\text { Product Transter Lines } \\
\text { Circins > } 5000\end{array}$ & momtrac & ThermTrac & Themintac & \\
\hline
\end{tabular}

Solb-Rogutating and Powor-Limitting Montling Cablos Produet Soloction

A. Soloct the Heat Tracling Famlly.

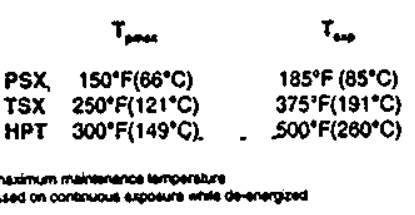

8. Locato the Pipe Maintaln Tomperature on Graph 1,2 or 3 . Find the heating cable power level that will latec heat loss, $O$.

Solocting a hoating cable with a higher output than sequired allows the cable to be appled in a straight run output requites spiralling or multiple passes of cable.

Calculate the Spiral factor $(L=$ loet of heating cabte tequlred per foot of plpe) by dividing $Q_{\text {, by heating cable }}$

For operation at voluges other than 120 and 240 Vac. refer to Chart 8 on page 7 .
Examplo: Hoating Cable Soloction

A. $T_{-3}=366^{\circ} F$, elect elther TSX or HPT. To choose between TSX and HPT, constder the lollowing:

a. TSX has a highat selt-ragulating index. . HPT can withstand higher tomporature exposures and has more power at higher

B. Power Output Required

$(0)=.7.4 \mathrm{w} / \mathrm{h} \odot 120^{\circ} \mathrm{F}$

Power Output TSX 9.1 $=8.3 \mathrm{w} / \mathrm{ft} \bullet 120^{\circ} \mathrm{F}$ (From Graph 2)

Splralling is not required in this examplo.

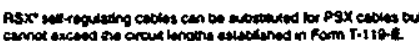

Graph 1: PSX Cable Pertormance

(Based on installation on an insulated motallie pipe)

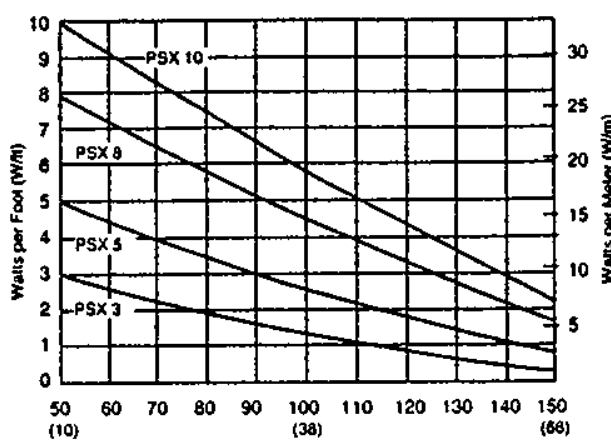

Insulated Metal Pipe Temperature ${ }^{\circ} \mathrm{F}\left({ }^{\circ} \mathrm{C}\right)$

PSX 120 and 240 Vac
PSX Cablo Porformance on Plastlc PIpe L-20P Aluminum Tape' on an insulated plastic pipe)

\begin{tabular}{|c|c|}
\hline PSX Cable & $\begin{array}{c}\text { Apply This foctor to PSX } \\
\text { Porformenco from Orsph 1 }\end{array}$ \\
\hline PSX 3 & 0.80 \\
\hline PSX 5 & 0.75 \\
\hline PSX 8 & 0.75 \\
\hline PSX 10 & 0.70 \\
\hline
\end{tabular}

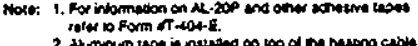

Graph 2: TSX Cabte Performance (Based on installation on an insulated metallle pipe)

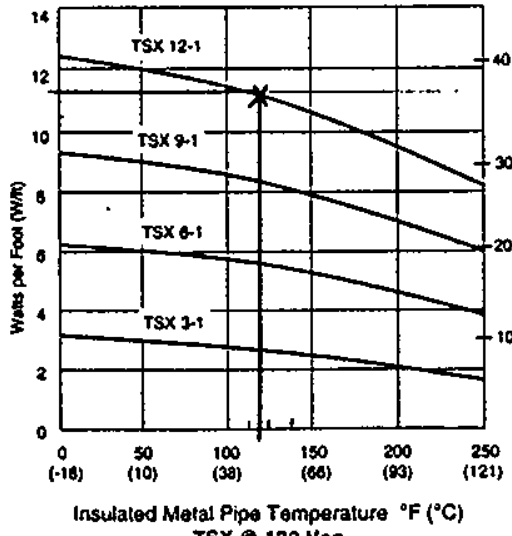
TSX 120 Vac

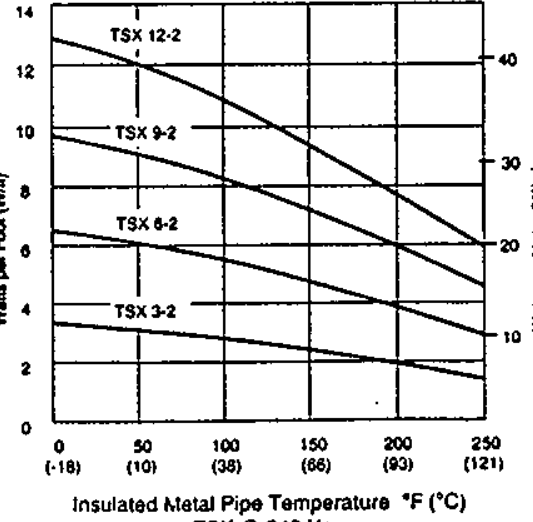

TSX $240 \mathrm{Vac}$

(2) 

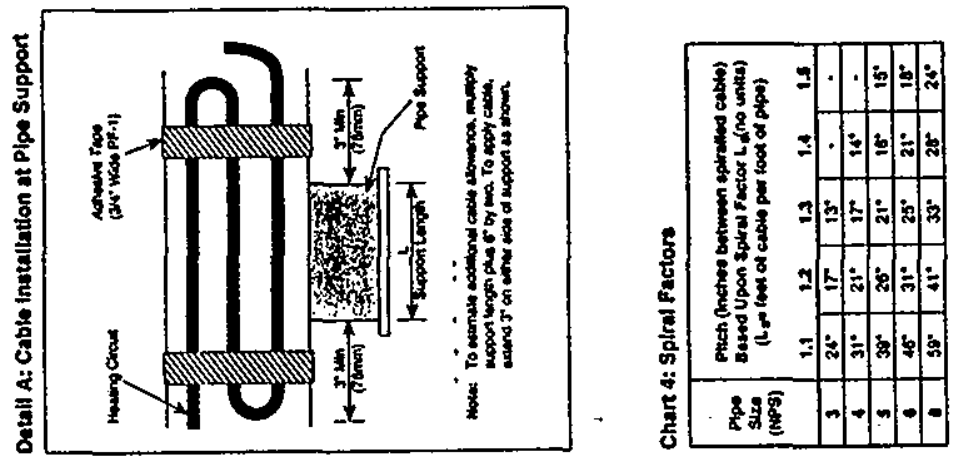

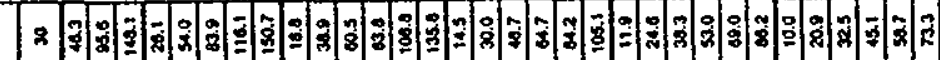

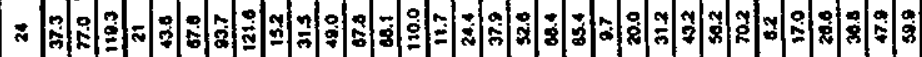

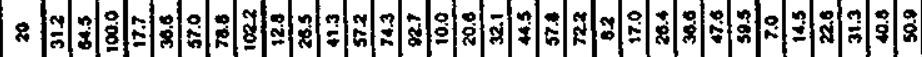

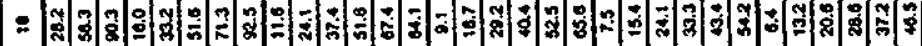

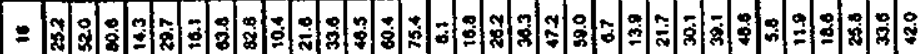

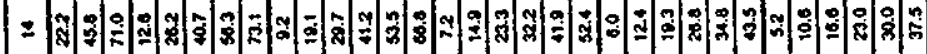

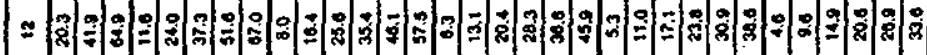

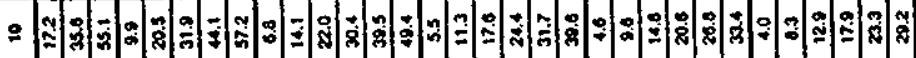

-

-

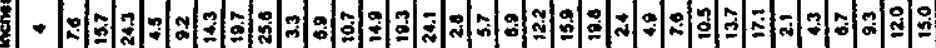

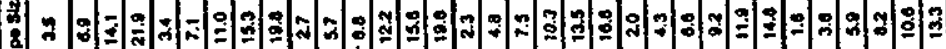

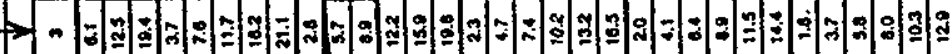

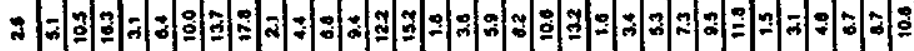

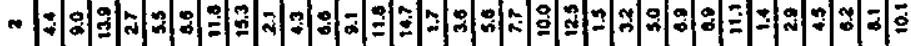

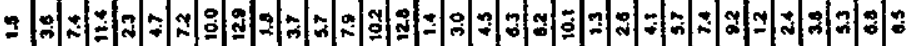

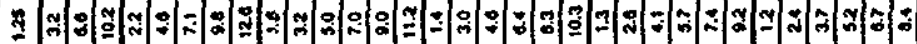

-

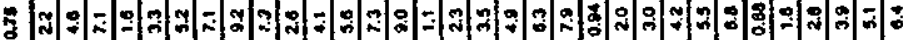

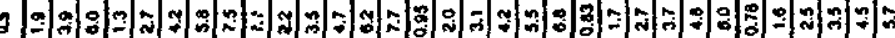

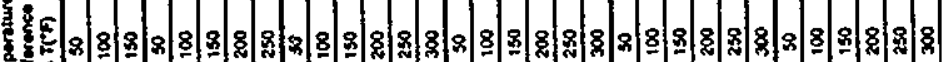
無4

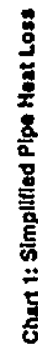

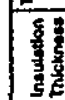
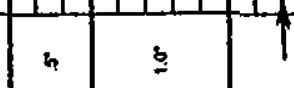
1

s

;

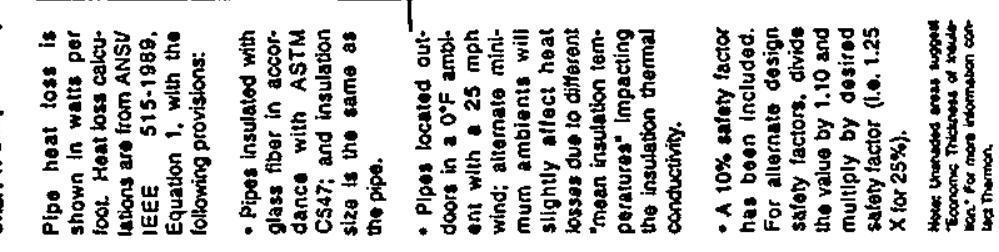

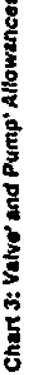
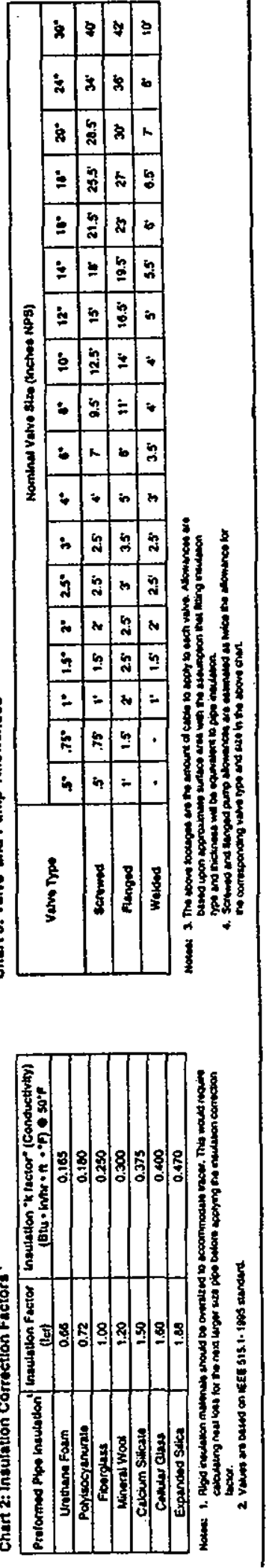
HNF-3477, Rev. 0

HEAT TRACING PRODUCT SELECTION (Cont'd)

Graph 3: HPT Cable Performance

(Based on installation on an insulated metallic pipe)

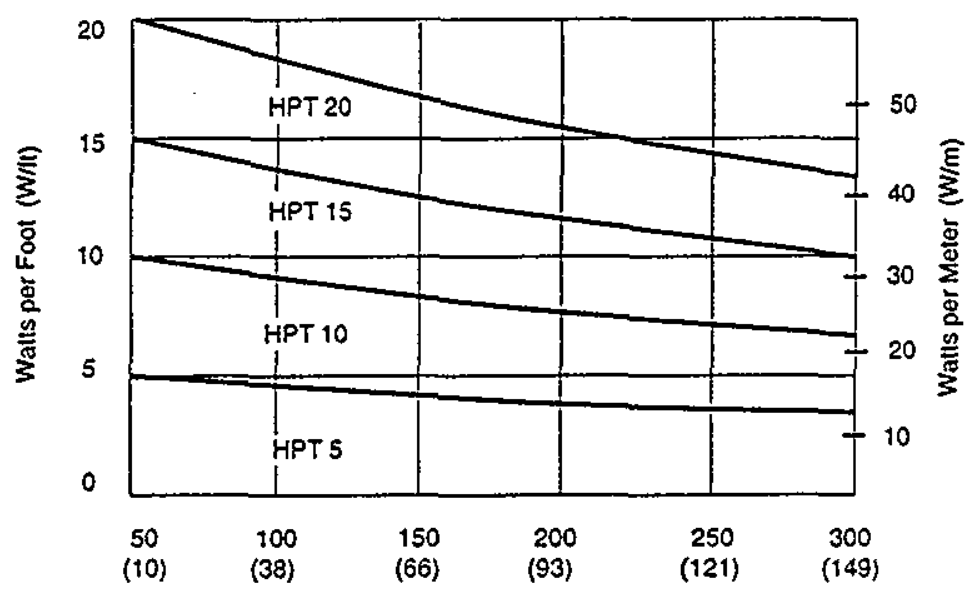

Insulated Metal Pipe Temperature ${ }^{\circ} \mathrm{F}\left({ }^{\circ} \mathrm{C}\right)$ HPT \& 120 and $240 \mathrm{Vac}$

C. Classified (Hazardous) Locations require metallic braided heating cable. Add BC for PSX or BN for TSX and HPT in Classes 1, II, III, Division 2 hazardous locations and for locations requiring grounding braid or additional mechanical protection.

(Contact Thermon if area classification is Division 1.)

Add option (.OJ) where additional corrosion protection is required. (PSX also available with fluoropolymer overjacket. Specify -FOJ option).

D. Calculate Heater Length $\left(L_{n}\right)$ per circuit by multiplying $L_{s} \times$ P.L. (pipe length) and adding allowances for valves and equipment. (See Chart 3 for allowances).

$L_{n}=\left(L_{s} \times P . L_{.}\right)+$valve, support and pump allowances

\section{CIRCUIT BREAKER SELECTION}

A. For self-regulating and power-limiting cables it is necessary to select a circuit breaker based on start-up at minimum ambient $\left(T_{2}\right)$ or the specified start-up temperature. Use Charts 5,6 or 7 to determine circuit breaker sizing requirements for $\mathrm{SX}^{\mathrm{N}}$ self-regulating and HPT power-limiting heating cables.

The maximum circuit lengths for circuit breakers shown are based on cold start on an insulated pipe at the temperatures shown. Circuit breaker sizing is based on the National Electrical Code (1996) Article 427.4.

\section{Example: Circuit Lengths}

C. Area Classification is Class I, Division 2. TSX cable requires BN metallic braid; overjacket option can be considered but may not be required.

D. Circuit 1 -

$$
\begin{aligned}
& L_{n t}=106 \mathrm{ft}+1(3.5 \mathrm{ft})+5(2.5 \mathrm{ft})+1(7 \mathrm{ft}) \\
& L_{n t}=129 \mathrm{ft} \text { of TSX } 9-1 \mathrm{BN}
\end{aligned}
$$

Circuit 2 -

$$
L_{12}=(34 \mathrm{ft})+1(3.5 \mathrm{ft})+1(2.5 \mathrm{tt})
$$$$
L_{n 2}=40 \mathrm{ft} \text {. of TSX 9-1 BN }
$$

Circuit 3 .

$$
\begin{aligned}
& L_{n 3}=(50 \mathrm{ft})+1(3.5 \mathrm{ft})+3(2.5 \mathrm{ft})+1(7 \mathrm{tt}) \\
& L_{n 3}=68 \mathrm{ft} \text { of TSX 9-1 BN }
\end{aligned}
$$

Example: Circuit Breaker Sizing

A. Circuit 1 will require a 20 amp circuit breaker, Circuits 2 and 3 can each be powered from a 15 amp circuit breaker (Refer to Chart 6). 


\section{CIRCUIT BREAKER SELECTION}

Chart 5: PSX Self-Regulating Heating Cables

\begin{tabular}{|c|c|c|c|c|c|}
\hline \multirow{2}{*}{\multicolumn{2}{|c|}{$\begin{array}{c}120 \text { Vac } \\
\text { Service Voltage }\end{array}$}} & \multirow{2}{*}{$\begin{array}{c}15 A \\
t(m) \\
\end{array}$} & \multirow{2}{*}{$\begin{array}{l}20 \mathrm{~A} \\
t \pi(\mathrm{m})\end{array}$} & \multirow{2}{*}{$\begin{array}{l}30 \mathrm{~A} \\
\mathrm{H}(\mathrm{m})\end{array}$} & \multirow{2}{*}{$\frac{40 A}{H(m)}$} \\
\hline & & & & & \\
\hline \multirow{4}{*}{$\begin{array}{l}\text { PSX 3-1 } \\
\text { If started at }\end{array}$} & $50^{\circ} \mathrm{F}\left(10^{\circ} \mathrm{C}\right)$ & 345 (145) & 355 (108) & $355(108)$ & $355(108)$ \\
\hline & $0^{\circ} \mathrm{F}\left(-18^{\circ} \mathrm{C}\right)$ & $200(61)$ & $290(88)$ & $355(108)$ & $355(108)$ \\
\hline & $-20^{\circ} \mathrm{F}\left(-29^{\circ} \mathrm{C}\right)$ & $170(52)$ & $245(75)$ & 355 (108) & $355(108)$ \\
\hline & $-40^{\circ} \mathrm{F}\left(-40^{\circ} \mathrm{C}\right)$ & $150(46)$ & $215(66)$ & $355(108)$ & $355(108)$ \\
\hline \multirow{4}{*}{$\begin{array}{c}\text { PSX 5-1 } \\
\text { If started at }\end{array}$} & $50^{\circ} \mathrm{F}\left(10^{\circ} \mathrm{C}\right)$ & $190(58)$ & $270(82)$ & $275(84)$ & $275(84)$ \\
\hline & $0^{\circ} \mathrm{F}\left(.18^{\circ} \mathrm{C}\right)$ & $125(38)$ & $170(52)$ & $275(84)$ & $275(84)$ \\
\hline & $20^{\circ} \mathrm{F}\left(-29^{\circ} \mathrm{C}\right)$ & $105(32)$ & $145(44)$ & $240(73)$ & $275(84)$ \\
\hline & $-40^{\circ} \mathrm{F}\left(-40^{\circ} \mathrm{C}\right)$ & $95(29)$ & $130(40)$ & $210(64)$ & $275(84)$ \\
\hline \multirow{4}{*}{$\begin{array}{l}\text { PSX 8-1 } \\
\text { if started at }\end{array}$} & $50^{\circ} \mathrm{F}\left(10^{\circ} \mathrm{C}\right)$ & $150(46)$ & $205(63)$ & $220(67)$ & $220(67)$ \\
\hline & $0^{\circ} \mathrm{F}\left(-18^{\circ} \mathrm{C}\right)$ & $100(30)$ & $140(43)$ & $220(67)$ & $220(67)$ \\
\hline & $20^{\circ} \mathrm{F}\left(-29^{\circ} \mathrm{C}\right)$ & $90(27)$ & $125(38)$ & $220(67)$ & $220(67)$ \\
\hline & $-40^{\circ} \mathrm{F}\left(-40^{\circ} \mathrm{C}\right)$ & $85(26)$ & $115(35)$ & $180(55)$ & $220(67)$ \\
\hline \multirow{4}{*}{$\begin{array}{c}\text { PSX 10-1 } \\
\text { if started at }\end{array}$} & $50^{\circ} \mathrm{F}\left(10^{\circ} \mathrm{C}\right)$ & $115(35)$ & $160(49)$ & $195(59)$ & $195(59)$ \\
\hline & $0^{\circ} \mathrm{F}\left(-18^{\circ} \mathrm{C}\right)$ & $80(24)$ & $115(35)$ & $180(55)$ & $195(59)$ \\
\hline & $20^{\circ} \mathrm{F}\left(-29^{\circ} \mathrm{C}\right)$ & $75(23)$ & $100(30)$ & $160(49)$ & $195(59)$ \\
\hline & $40^{\circ} \mathrm{F}\left(-40^{\circ} \mathrm{C}\right)$ & $70(21)$ & $95(29)$ & $145(44)$ & $195(59)$ \\
\hline
\end{tabular}

\begin{tabular}{|c|c|c|c|c|c|}
\hline \multirow{2}{*}{\multicolumn{2}{|c|}{$\begin{array}{c}240 \text { Vac } \\
\text { Service Voltage }\end{array}$}} & $15 A$ & $20 \mathrm{~A}$ & $30 \mathrm{~A}$ & $40 \mathrm{~A}$ \\
\hline & & $t(m)$ & $t t(m)$ & $\mathrm{ft}(\mathrm{m})$ & $t(m)$ \\
\hline \multirow{4}{*}{$\begin{array}{l}\text { PSX 3-2 } \\
\text { if started at }\end{array}$} & $50^{\circ} \mathrm{F}\left(10^{\circ} \mathrm{C}\right)$ & $635 .(194)$ & $715(218)$ & $715(218)$ & $715(218)$ \\
\hline & $0^{\circ} \mathrm{F}\left(-18^{\circ} \mathrm{C}\right)$ & $390(119)$ & $545(166)$ & $715(218)$ & $715(218)$ \\
\hline & $20^{\circ} \mathrm{F}\left(-29^{\circ} \mathrm{C}\right)$ & 335 (102) & $470(143)$ & $715(218)$ & $715(218)$ \\
\hline & $-40^{\circ} \mathrm{F}\left(-40^{\circ} \mathrm{C}\right)$ & 300 (91) & 410 (125) & $690(210)$ & $690(210)$ \\
\hline \multirow{4}{*}{$\begin{array}{c}\text { PSX 5.2 } \\
\text { If started at }\end{array}$} & $50^{\circ} \mathrm{F}\left(10^{\circ} \mathrm{C}\right)$ & $380(116)$ & $530(162)$ & $550(168)$ & $550(168)$ \\
\hline & $0^{\circ} \mathrm{F}\left(-18^{\circ} \mathrm{C}\right)$ & $245(75)$ & $335(102)$ & $550(168)$ & $550(168)$ \\
\hline & $20^{\circ} \mathrm{F}\left(-29^{\circ} \mathrm{C}\right)$ & $215(66)$ & $295(90)$ & $475(145)$ & $550(168)$ \\
\hline & $-40^{\circ} \mathrm{F}\left(-40^{\circ} \mathrm{C}\right)$ & $195(59)$ & $265(81)$ & $420(128)$ & $550(168)$ \\
\hline \multirow{4}{*}{$\begin{array}{c}\text { PSX 8.2 } \\
\text { If started at }\end{array}$} & $50^{\circ} \mathrm{F}\left(10^{\circ} \mathrm{C}\right)$ & $295(90)$ & $410(125)$ & 435 (133) & 435 (133) \\
\hline & $0^{\circ} \mathrm{F}\left(-18^{\circ} \mathrm{C}\right)$ & $205(63)$ & $280(85)$ & 435 (133) & $435(133)$ \\
\hline & $-20^{\circ} \mathrm{F}\left(\cdot 29^{\circ} \mathrm{C}\right)$ & $185(56)$ & $250(76)$ & $400(122)$ & 435 (133) \\
\hline & $40^{\circ} \mathrm{F}\left(-40^{\circ} \mathrm{C}\right)$ & $165(50)$ & $225(69)$ & $360(110)$ & $435(133)$ \\
\hline \multirow{4}{*}{$\begin{array}{c}\text { PSX 10-2 } \\
\text { if started at }\end{array}$} & $50^{\circ} \mathrm{F}\left(10^{\circ} \mathrm{C}\right)$ & $230(70)$ & $320(98)$ & $390(119)$ & $390(119)$ \\
\hline & $0^{\circ} \mathrm{F}\left(-18^{\circ} \mathrm{C}\right)$ & $165(50)$ & $225(69)$ & $360(110)$ & $390(119)$ \\
\hline & $20^{\circ} \mathrm{F}\left(-29^{\circ} \mathrm{C}\right)$ & $150(46)$ & $205(63)$ & $325(99)$ & $390(119)$ \\
\hline & $-40^{\circ} \mathrm{F}\left(-40^{\circ} \mathrm{C}\right)$ & $140(43)$ & $190(58)$ & $295(90)$ & $390(119)$ \\
\hline
\end{tabular}

Chart 6: TSX Self-Regulating Heating Cables These lengths are suitable for systems at any ambient at or below $+50^{\circ} \mathrm{F}\left(10^{\circ} \mathrm{C}\right)$

\begin{tabular}{|c|c|c|c|c|}
\hline \multicolumn{2}{|c|}{120 Vac Service Voltage } & \multicolumn{3}{|c|}{$\begin{array}{c}\text { Max Clrcuit Length Based on } \\
\text { Clreuit Breaker Sizing }\end{array}$} \\
\hline $\begin{array}{l}\text { Catalog } \\
\text { Numbet }\end{array}$ & $\begin{array}{c}\text { Output } ~ 50^{\circ} \mathrm{F} \\
\text { watts/tt (w/m) }\end{array}$ & th. $(\mathrm{m})$ & tt. (m) & th (m) \\
\hline TSX 3-1 & $3(10)$ & $245(75)$ & $325(99)$ & $355(108)$ \\
\hline TSX 6-1 & $6(20)$ & $160(49)$ & $210(64)$ & $245(75)$ \\
\hline TSX 9-1 & $9(30)$ & $120(37)$ & $160(49)$ & $200(61)$ \\
\hline TSX 12-1 & $12(39)$ & $90(27)$ & $120(37)$ & $175(53)$ \\
\hline
\end{tabular}

\begin{tabular}{|c|c|c|c|c|}
\hline \multicolumn{2}{|c|}{240 Vac Service Voltage } & \multicolumn{3}{|c|}{$\begin{array}{l}\text { Max Circuit Length Based on } \\
\text { Circult Breaker Sizing }\end{array}$} \\
\hline \multirow{2}{*}{$\begin{array}{l}\text { Catalog } \\
\text { Number }\end{array}$} & \multirow{2}{*}{$\begin{array}{l}\text { Output } \odot 50^{\circ} \mathrm{F} \\
\text { watts } / t t(\mathrm{w} / \mathrm{m})\end{array}$} & 15A & $20 \mathrm{~A}$ & $30 \mathrm{~A}$ \\
\hline & & ft. $(m)$ & th. (m) & ft. (m) \\
\hline TS $\times 3-2$ & $3(10)$ & $480(146)$ & 640 (195) & 715 (218) \\
\hline TSX & $6\{20)$ & 6) & $420(128)$ & $505(154)$ \\
\hline TSX 9-2 & $9(30)$ & $240(73)$ & $320(98)$ & $410(125)$ \\
\hline TSX 12.2 & $12(39)$ & $170(52)$ & $230(70)$ & $345(105)$ \\
\hline
\end{tabular}

\section{Chart 7: HPT Power-Limiting Heating Cables}

\begin{tabular}{|c|c|c|c|c|c|c|}
\hline \multicolumn{2}{|c|}{120 Vac Serviee Voltage } & \multicolumn{5}{|c|}{$\begin{array}{l}\text { Max Clreult Length Basod on Clireult Breaker Slzing } \\
t(\mathrm{~m})\end{array}$} \\
\hline $\begin{array}{l}\text { Catslog } \\
\text { Number }\end{array}$ & $\begin{array}{l}\text { Start } \\
\text { Temp } \\
\text { "F(C C }\end{array}$ & 15A & $20 A$ & $30 A$ & 40A & 50A \\
\hline \multirow{4}{*}{ HPT $5.1 \mathrm{BN}$} & $50(10)$ & $255(78)$ & $350(107)$ & 435 (133) & 435 (133) & $435(133)$ \\
\hline & $O(-18)$ & $230(70)$ & $315(96)$ & 435 (133) & $435\{(133)$ & 435 (133) \\
\hline & $.20(-29)$ & 225 (69) & $305(93)$ & $435(133)$ & 435 (133) & 435 (133) \\
\hline & $-40(-40)$ & $215(66)$ & $290(88)$ & $435(333)$ & 435 (133) & 435 (133) \\
\hline \multirow{4}{*}{ HPT $10.18 \mathrm{~N}$} & $50(10)$ & $125(38)$ & $170(52)$ & $255(78)$ & $310(95)$ & $435(133)$ \\
\hline & $0(-19)$ & 115 (35) & $155(47)$ & $240(73)$ & $310(95)$ & $435(133)$ \\
\hline & $.20(-29)$ & $110(34)$ & $150(46)$ & $230(70)$ & $310(95)$ & $435(133)$ \\
\hline & $-40(-40)$ & $105(32)$ & $140(43)$ & $220(67)$ & $305(93)$ & 310 (95) \\
\hline \multirow{4}{*}{ HPT 15-1 BN } & $50(10)$ & $80(24)$ & $110(34)$ & $170(52)$ & $240(73)$ & $250(76)$ \\
\hline & $0(-98)$ & $75(23)$ & $100(30)$ & $155(47)$ & $215(66)$ & $250(76)$ \\
\hline & $.20(-29)$ & $70(21)$ & $95(29)$ & $150(46)$ & $205(63)$ & $250(76)$ \\
\hline & $-40(-40)$ & $70(21)$ & $95(29)$ & $145(44)$ & $195(59)$ & $250(76)$ \\
\hline \multirow{4}{*}{ MPT 20-1 BN } & 50 (10) & $80(18)$ & $80(24)$ & $125(38)$ & $175(53)$ & $215(66)$ \\
\hline & O $(-: 8)$ & $55(17)$ & $75(23)$ & t15 (35) & $155(47)$ & $200(61)$ \\
\hline & $.20(.29)$ & $55(17)$ & $70(21)$ & $110(34)$ & $150(46)$ & $195(59)$ \\
\hline & $-40(-40)$ & so (15) & $70(21)$ & $105(32)$ & 145 (44) & $185(58)$ \\
\hline
\end{tabular}

\begin{tabular}{|c|c|c|c|c|c|c|}
\hline \multicolumn{2}{|c|}{240 Vac Service Voltage } & \multicolumn{5}{|c|}{$\begin{array}{l}\text { Max Circult Length Based on Clreult Bresker Sizing } \\
\text { in (m) }\end{array}$} \\
\hline $\begin{array}{l}\text { Catalog } \\
\text { Numbur }\end{array}$ & $\begin{array}{l}\text { Start } \\
\text { Temp } \\
\left.{ }^{\circ} \cdot{ }^{\circ} \mathrm{C}\right) \\
\end{array}$ & $15 A$ & $20 \mathrm{~A}$ & $30 \mathrm{~A}$ & $40 A$ & sou \\
\hline \multirow{4}{*}{ HPT $5.28 \mathrm{~N}$} & $50(10)$ & $515(157)$ & $705(215)$ & $875\{267)$ & $875(267)$ & $875(287)$ \\
\hline & $0(-18)$ & $465(142)$ & 635 (194) & $875(287)$ & $875(267)$ & $875(267)$ \\
\hline & $-20(-29)$ & $450(137)$ & $610(188)$ & $875(267)$ & $875(267)$ & $875(287)$ \\
\hline & $.40(40)$ & $430(131)$ & $585(178)$ & $975(267)$ & $875(267)$ & $875\{287$ \\
\hline \multirow{4}{*}{ HPT $10.2 \mathrm{BN}$} & $50(10)$ & $250(76)$ & $340(104)$ & $530(162)$ & $620(189)$ & $875(267)$ \\
\hline & $0(-18)$ & $230(70)$ & $310(95)$ & $480(946)$ & $620(189)$ & $875(267)$ \\
\hline & $.20(-29)$ & $220(67)$ & $300(91)$ & $460(140)$ & $620(189)$ & $875(267)$ \\
\hline & $-40(-40)$ & $215(66)$ & $265(87)$ & $440(134)$ & $810(188)$ & $620(189)$ \\
\hline \multirow{4}{*}{ HPT 15.2 BN } & $50(10)$ & $165(50)$ & $225(69)$ & $345(105)$ & $490(148)$ & $505(154)$ \\
\hline & $0(-18)$ & $150(46)$ & $205(63)$ & $315(96)$ & $430(131)$ & $505(154$ \\
\hline & $-20(-29)$ & $345(44)$ & $195(59)$ & $300(91)$ & $4: 0(125)$ & $505(154$ \\
\hline & $40(-40)$ & $940(43)$ & $190(58)$ & $290(88)$ & $395(120)$ & $505(154)$ \\
\hline \multirow{4}{*}{ MPT $20-28 \mathrm{~N}$} & $50(10)$ & $125(38)$ & $165(50)$ & $255(78)$ & $350(107)$ & $435(133)$ \\
\hline & $O(-18)$ & $115(35)$ & $150(46)$ & $230(70)$ & $315(96)$ & $400(122)$ \\
\hline & $-20(+29)$ & $110(34)$ & $145(44)$ & $225(69)$ & $305(93)$ & $390(t 99$ \\
\hline & $-40(-40)$ & $105(32)$ & $140(43)$ & $215(66)$ & $290(88)$ & $375(114)$ \\
\hline
\end{tabular}




\section{ALTERNATE VOLTAGE INFORMATION}

Chart 8: Power Output Correction Factors for SX Self-Regulating and HPT Power-Limiting Cables

\begin{tabular}{|c|c|c|c|}
\hline $\begin{array}{c}120 \text { Vac } \\
\text { SX Cables }\end{array}$ & $\begin{array}{c}100 \\
\text { Vac }\end{array}$ & $\begin{array}{c}110 \\
\text { Vac }\end{array}$ & $\begin{array}{l}130 \\
\text { Vac }\end{array}$ \\
\hline PSX 3-1 & 0.76 & 0.90 & 1.10 \\
\hline PSX 5-1 & 0.80 & 0.90 & 1.08 \\
\hline PSX 8-1 & 0.82 & 0.91 & 1.08 \\
\hline PSX 10.1 & 0.84 & 0.93 & 1.08 \\
\hline TSX 3.1 & 0.71 & 0.85 & 1.15 \\
\hline TSX 6.1 & 0.71 & 0.85 & 1.15 \\
\hline TSX 9-1 & 0.74 & 0.88 & 1.12 \\
\hline TSX 12-1 & 0.77 & 0.88 & 1.12 \\
\hline
\end{tabular}

\begin{tabular}{|c|c|c|c|}
\hline $\begin{array}{c}240 \text { Vac } \\
\text { SX Cables }\end{array}$ & $\begin{array}{c}208 \\
\text { Vac }\end{array}$ & $\begin{array}{c}220 \\
\text { Vac }\end{array}$ & $\begin{array}{l}277 \\
\text { Vac }\end{array}$ \\
\hline PSX 3-2 & 0.80 & 0.87 & 1.20 \\
\hline PSX 5.2 & 0.88 & 0.92 & 1.14 \\
\hline PSX 8-2 & 0.91 & 0.95 & 1.09 \\
\hline PSX 10-2 & 0.95 & 0.97 & 1.08 \\
\hline TSX 3-2 & 0.76 & 0.85 & 1.30 \\
\hline TSX 6-2 & 0.77 & 0.85 & 1.29 \\
\hline TSX 9-2 & 0.78 & 0.86 & 1.25 \\
\hline TSX 12-2 & 0.80 & 0.88 & 1.21 \\
\hline
\end{tabular}

\begin{tabular}{|c|c|c|c|c|c|c|}
\hline $\begin{array}{c}\text { HPT } \\
\text { Cables }\end{array}$ & $\begin{array}{l}100 \\
\text { Vac }\end{array}$ & $\begin{array}{l}110 \\
\text { Vac }\end{array}$ & $\begin{array}{c}130 \\
\text { Vac }\end{array}$ & $\begin{array}{c}208 \\
\text { Vac }\end{array}$ & $\begin{array}{l}220 \\
\text { Vac }\end{array}$ & $\begin{array}{l}277 \\
\text { Vac }\end{array}$ \\
\hline HPT 5-1 & 0.70 & 0.85 & 1.16 & NA & NA & NA \\
\hline HPT 10-1 & 0.70 & 0.85 & 1.16 & NA & NA & NA \\
\hline HPT 15-1 & 0.70 & 0.85 & 1.16 & NA & NA & NA \\
\hline HPT 20.1 & 0.70 & 0.85 & 1.16 & NA & NA & NA \\
\hline HPT 5-2 & NA & NA & NA & 0.77 & 0.85 & 1.27 \\
\hline HPT 10-2 & NA & NA & NA & 0.77 & 0.85 & 1.27 \\
\hline HPT 15-2 & NA & NA & NA & 0.77 & 0.85 & 1.27 \\
\hline HPT 20.2 & NA & NA & NA & 0.77 & 0.85 & NA \\
\hline
\end{tabular}

\section{BASIC ACCESSORIES}

Power Connection:

All PSX cables require the TBX-3L boot for terminating the circuit before connecting to power. This component is included with standard connection kits.

All TSX cables require the TBX-3L boot for terminating the circuit before connecting to power.

All HPT cables require the TBX-4L boot for terminating the circuit before connecting to power.
End-of-Circuit Termination:

All PSX cables with $B C$ require the ET-8 end cap for terminating at the end of the circuit. All PSX cables with either the Overjacket (OJ or FOJ option) and/or Monitor Wire (MC option) require the ET-6 end cap for terminating at the end of the circuit.

All TSX cables with BN require the ET-8 end cap for terminating at the end of the circuit. All TSX cables with either the Overjacket (OJ option) and/or Monitor Wire (MC option) require the ET.6 end cap for terminating at the end of the circuit.

All HPT cables with BN require the ET-8 end cap for terminating at the end of the circuit. All HPT cables with either the Overjacket (OJ option) and/or Monitor Wire (MC option) require the ET-6 end cap for terminating at the end of the circuit.

Article 427-23. Metal Covering. Electric heating equipment shall have a grounded metal covering in accordance with (a) or (b) below. The requirements of this section shall become effective July $1,1996$.

(a) Heating Wires and Cables. Heating wires or cables shall have a grounded metal covering that surrounds the heating element and bus wires, if any, and their electrical insulation.

(b) Heating Panels. Heating panels shall have a grounded metal covering over the heating element and its electrical insulation on the side opposite the side attached to the surface to be heated. The metal covering shall provide an effective ground path." 


\section{DISTRIBUTION SHEET}

\begin{tabular}{l|l|l}
\hline To $\begin{array}{l}\text { Distribution } \\
\text { Droject Title/Work Order }\end{array}$ & $\begin{array}{l}\text { From } \\
\text { Interim Stabilization } \\
\text { Engineering }\end{array}$ & Date 1 of 1 \\
\hline \multirow{2}{\text{S-FarmOvergroundTransfer(OGT)Line/103360/EF00-588/50}}{} & EDT No. 612794 \\
\cline { 2 - 2 } & ECN No. N/A \\
\hline
\end{tabular}

\begin{tabular}{c|c|c|c|c|c}
\hline Name & MSIN & $\begin{array}{c}\text { Text } \\
\text { With } \\
\text { All } \\
\text { Attach. }\end{array}$ & $\begin{array}{c}\text { Text } \\
\text { Only }\end{array}$ & $\begin{array}{c}\text { Attach./ } \\
\text { Appendix } \\
\text { Only }\end{array}$ & $\begin{array}{c}\text { EDT/ECN } \\
\text { Only }\end{array}$ \\
\hline
\end{tabular}

Brevick, Chris H. Crawford, Jim A. Doeler, Jeff $N$. Ellingson, Kelly

Erlandson, Bradley G. Gaddis, Larry A. Hicks, Dale F. Holbrook, Doug S. Hu17, Kevin J. Jaka, Omar M. Koch, Mike R. Larson, Rich E. McDona1d, J. Dan Miller, Phillip C. Nguyen, Toan $\mathrm{H}$. Raven, Bexa P. Saueressig, Dave J. Swarers, Tom A.

Tipps, Mike C. True, Roger R. Volkman, Terry J. V1adimiroff, David T. Wiggins, Dirk D. Wiggins, J. Dewayne Zuroff, Bill F. DOE-RL Reading Room FDNW TDC
B4-57

S7-20

T4-07

S7-24

R1-51

H5-57

S7-24

S5-50

T4-07

S7-34

S7-24

T4-07

S7-20

R1-51

S7-24

S7-21

S7-20

S7-20

S7-34

T4-07

T4-07

S7-20

S7-24

S7-20

S7-24

H2-55

E6-02 $x$
$x$
$x$
$x$
$x$
$x$
$x$
$x$
$x$
$x$
$x$
$x$
$x$
$x$
$x$
$x$
$x$
$x$
$x$
$x$
$x$
$x$
$x$
$x$
$x$
$x$
$x$ 